\title{
A COMPARAIIVE STUDY OF ENDOTHELIN AND SARAFOTOXIN ACTION IN VASCULAR AND NON-VASCULAR SMOOTH MUSCLE
}

\section{CENTRE FOR NEWFOUNDLAND STUDIES}

\section{TOTAL OF 10 PAGES ONLY MAY BE XEROXED}

(Without Author's Permission)

EKONG ITO EKONG ETA 


A COMPARATIVE STUDY OF ENDOTHELIN AND SARAFOTOXIN ACTION IN VASCULAR AND NON-VASCULAR SMOOTH MUSCLE

BY

EKONG ITO EKONG ETA. B.H., B.Ch (Nig.)

A thesis submitted to the school of Graduate studies in partial fulfilment of the requirements for the degree of Master of science

Faculty of Medicine

Memorial University of Newfoundland Spring 1991

st. John's

Newfoundland 
National Library

of Canada

Acquisitions and

Bibliographic Services Branch

395 Welinglon Street

Ontawa. Ontaria

KIA ON4
Bibliotheque nationale

du Canada

Direction des acquisitions el des services bibliographiques

395, nue Wellington

Ottawa (Onterio)
Pou tis Votre aftionse

Our the Nolre reterance
The author has granted an irrevocable non-exclusive licence allowing the National Library of Canada to reproduce, loan, distribute or sell copies of his/her thesis by any means and in any form or format, making this thesis available to interested persons.
L'auteur a accordé une licence irrévocable et non exclusive permettant à la Bibliothèque nationale du Canada de reproduire, prêter, distribuer ou vendre des copies de sa thèse de quelque manière et sous quelque forme que ce soit pour mettre des exemplaires de cette thèse à la disposition des personnes intéressées.
The author retains ownership of the copyright in his/her thesis. Neither the thesis nor substantial extracts from it may be printed or otherwise reproduced without his/her permission.
L'auteur conserve la propriété du droit d'auteur qui protège sa thèse. Ni la thèse ni des extraits substantiels de celle-ci ne doivent être imprimés ou autrement reproduits sans son autorisation. 
il

This thesis ia dedicated to $m y$ paronts and to my son, Ito. 


\section{ABSTRACT}

The hypothesig that endothelin (ET-1) is the endogenous ligand for "sarafotoxin receptors" (SRTX receptora) was examined. The actions of ET-1 and SRTX-b were compared with those of the well characterized vagocongtrictcr, norepinephrine (NE). The rationale was to identify and compare the transduction-ef fector mechanisms of these peptides versus NE in vascular and non-vascular smooth muk-les.

In this study, the rat aorta and anococcygeus mugcles were uged as repregentatives of vascular and non-vascular smooth muscle, respectively. The role of extracellular $\mathrm{Ca}^{2+}$ was studied by omitting $\mathrm{Ca}^{2+}$ from the physiological aaline solution, and the contribution of voltage-operated $\mathrm{Ca}^{2+}$ channels (VocCs) assesged by determining the effects of nifedipine. In addition, the effects of ryanodine, which interferes with the release of cellular $\mathrm{Ca}^{2+}$, was also studled. The roles of arachidonic acid products were determined by studying the effects of the cyclooxygenase inhibitor, Indomethacin, and the lipoxygenase inhibltor, nordihydroguaiaretic acid (NDGA). The contractions elicited by $\mathrm{ET}-1$ and $\mathrm{SRTX}-\mathrm{b}(10 \mathrm{nM})$, or $N E(1 \mu \mathrm{M})$ were approximately equieffective in terms of tension developement and correspond to ECSO values, and these concentrations were thus used throughout the study. In $\mathrm{Ca}^{2+}-\mathrm{free} \mathrm{Krebs}$, the three agonists generated approximately aimllar lavels of tone in the aorta and $t$ ': $q$ anococcygeus corresponding to 18 and 5 of the maximum response, respectively. Nifedipine, $10 \mu \mathrm{M}$, oignificantly inhibited responses to ET-1 in both the aorta and anococcygeus; the responses to SRTX-b and NE were, however, not gignificantly affected in either tissue. A combination of $10 \mu \mathrm{M}$ ryanodine and nifedipine caused near complete inhibition of response to $\mathrm{ET}-1$ in the aorta and also significantly 
reduced the responge to both $\mathrm{ET}-1$ and $\mathrm{NE}$ in the anococcygeus. The 1ipoxygenase inhibitor, NDGA, inhibited the response to ET-1 in ti:e aorta and ET-1 and NE in the anococcygeus mugcle. The cyclooxygenase inhibitor, indomethacin, however, had no effect on the responses to any of the three agonists in either the aorta or anococoygeus. At concentratiorg greator than $30 \mathrm{nH}$ both ET-1 and SRTX-b induced myogenic activity in normally quiescent anococcygeus mugcle. As determined by the loss of myogenic activity, the tisaues recovered more rapidly from SRTX-b than ET-1, with complete recovery apparent after $2.62 \pm 0.85$ and $5.22 \pm 0.06 \mathrm{~h}$, respectively. Omitting Ca $\mathrm{from}^{2+}$ the Krebs solution reduced recovery times to $1.62 \pm 0.2$ and $2.4 \pm 0.51 \mathrm{~h}$, reapectively.

In conclusion, the atudies performed indicate that a number of cell signalling procegges are activated by ET-1 and SRTX-b in smooth muscle and this could account for the varied responses. The suggestion that ET-1 Bolely acts on the 'SRTX receptor,' as proposed by Kloog and sokolovsky (1989), Is probably too simplistic. Reaults from this otudy also indicate that tiasue variability does exist and, Ladeed, subclasses of ET/SRTX receptors have been Inferred by others (Yanagisawa and Masaki, 1989b; Nayler, 1990). 


\section{ACKNOWLEDGEMENTS}

The author wishes to express sincere gratitude to Dr. C.R. Triggle for his unflinching support and supervision throughout the programe.

Gratitude is also expressed to members of the supervisory committee, Dr. A. Rankin and Dr. V. Richardson, for patience and understanding for the duration of the programme.

Informal discussions with Dr. Reza Tabrizchi and Dr. Ayo Aduagbo were most useful and greatly appreclated.

I would like to acknowledge the flnanclal support of the Medical Research Council of Canada and Faculty of Medieine of Memorial Univeraity.

Finally, I thank my wife, hsibong, for her steadfastnees. 
Portions of this thesis have been published in a peer reviewed Journal:

Eta, E. and Triggle, C.R. (1991) A comparative otudy of endothelin and sarafotoxin action in vascular and non-vascular smooth mugcle. Neurochem. Int. $18,559-564$. 
TABLE OF CONTENTS

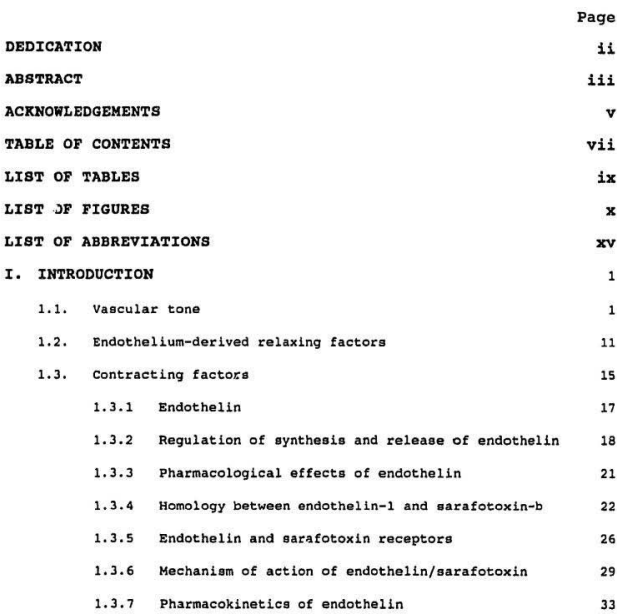

1.4. Objectives 35

2. METHODS AND MATERIALS 37

2.1. Animals 37

2.2. Choice of tisgue 37 
2.3. Tissue preparation

2.4. Experimental protocol

Study 2: Role of extracellular calcium $\left(\mathrm{Ca}^{2+}\right)$

study 3: Role of extracellular and intracellular calcium $\left(\mathrm{Ca}^{2+}\right)$

2.5. Composition of buffers

2.6. Drugs and chemicals

2.7. Statistics

study: 1

4.1. General considerations

4.2. Role of extracellular calcium $\left(\mathrm{Ca}^{2+}\right)$ 180

4.3. Role of arachidonic acid metabolites 


\section{LIST OF TABLES}

Page

Table 1 Time-dependent variation in the response of the anococcygeus muscle to four concentration-response curves obtained to NE over a four hour period.

Table 2 Effect of $\mathrm{Ca}^{2+}$-omisaion on recovery time (hours) of the anococcygeus muacle from peptide-induced myogenie activity.

Tabla 3 Effect of the removal of extracellular $\mathrm{Ca}^{2 *}$ on the contractile responges of the anococcygeug muscle and aorta to $E T-1$, SRTX-b and $N E$.

Table 4 Comparison of \& changes in the responses to ET-1, SRTX-b and NE. 
Figure 1 Schematic representation of receptor activation by agonist and post receptor events.

Figure 2 Comparison of amino acid sequence of endothelin family with ocrafotoxin family.

Figure 3 Concentration-response curves of ET-1, SRTK-b and $N E$ in the portal vein of the rat.

Figure 4 Illustration of portal vein gensitivity by two parameters - frequency and amplitude to agonists.

Figure 5 Concentration response curves for ET-1, STRX-b and NE with the anococcygeus musele in normal Kreba buffer.

Figure 6 Induction of myogenic activity in the anococcygeug muscle following washout of A) $0.1 \mu \mathrm{M} \mathrm{ET-1;}$ B) $0.1 \mu \mathrm{M}$ SRTX-b with normal Krebs buffer.

Figure 7 Illustration of the responge to equieffective concentration of ET-1, STRX-b and NE at their approximate $\mathrm{EC}_{50}$ in :- a) anococcygeus and b) aorta.

Figure 8 Illustration of maintained tone induced by ET-1 and SRTX-b compared to non-sustained tone induced by $\mathrm{NE}$ in $\mathrm{Ca}^{2+}$-free Krebs buffer.

Figure $9(a, b$ and $c)$ Ef fect of nifedipine on $\mathrm{Ca}^{2+}$ concentration-response curves obtained in the corta in the presence of a) ET-1; b) SRTX-b and c) NE.

Figure 10( $a, b$ and $c)$ Ef fect of nlfedipine on calcium concentration-response curves obtained in the anococcygeus in the presence of a) ET-1, b) SRTX-b and c) NE.

Pigure 11( $a, b$ and $c)$ Illuatration of the persistent effect of nifediplne on $\mathrm{Ca}^{2+}$ concentration -response curves obtained in the aorta in the presence of a) ET-1, b) SRTX-b and c) NE. 
Figure $12(a, b$ and c) rllustration of persigtent inhibition following nifedipine application on $\mathrm{Ca}^{2+}$ concentration-response curves obtained in the anococcygeus in the presence of a) $E T-1$, b) SRTX-b and e) NE.

Figure 13 A comparison of the contractile effects induced by ET-1, $S R T X-b$ and $W E$ in the rat anococeygeus preparation in normal $\mathrm{Krebs}, \mathrm{Ca}^{2+}-\mathrm{free}$ and post-ryouvitine treatment in normal Krebs.

Figure 14 A comparison of the costractilst effects induced by BT-1, SRTX-b and $V E$ in the rat aortic ring preparation in normal Krebs, $\mathrm{Ca}^{2+}-\mathrm{free}$ and post ryanodine treatment in normal Krebs.

Figure $15(a, b$ and $c)$ Effect of ryanodine on $\mathrm{Ca}^{2+}$ concentration-response curves obtained in the anococcygeus in the presence of a) ET-1, b) SRTX-b and c) NE.

Figure $16(\mathrm{a}, \mathrm{b}$ and $\mathrm{c})$

Figure 17 (a and b)

Figure $18(a, b$ and $c)$

Figure $19(a, b$ and $c$

Figure 20 (a, b and $c)$
Effect of ryanodine on $\mathrm{Ca}^{2+}$ concentration-response curves obtalned in the aorta in the presence of

a) ET-1, b) SRTX-b and c) NE.

Illustration in. a) anococcygeus and b) aorta that repeated stimulation with $\mathrm{NE}$ in $\mathrm{Ca}^{2+}$-free Krebs can reduce the $t$ issue response to a certain level beyond which further attenuation is not posstble.

Effect of $\mathrm{NE}-$ induced $\mathrm{Ca}^{2+}$ depletion on $\mathrm{Ca}^{2+}$ concentration-response curves obtained in the anococcygous in the presence of a) $\mathrm{ET}-1, \mathrm{~b}) \mathrm{sR}(\mathrm{XX}-\mathrm{b}$ and c) $\mathrm{NE}$.

Effect of $\mathrm{NE}-$ induced $\mathrm{Ca}^{2+}$ depletion on $\mathrm{Ca}^{2+}$ concentration-responge curveg obtained in aorta in the presence of a) ET-1, b) SRTX-b and c) NE.

Effect of sequential $\mathrm{NE}$ and ryanodine - induced $\mathrm{Ca}^{2+}$ depletion on $\mathrm{Ca}^{2+}$ concentration-response curves obtained in 
the anococcygeus in the presence of

Figure 21 (a, b and c)

Effect of gequential NE and ryanodine - induced $\mathrm{Ca}^{2+}$ depletion on $\mathrm{Ca}^{2+}$ concentration-response curves obtained in the aorta in the presence of a) ET-1, b) SRTX-b and c) NE.

Figure 22 (a, b and c) Comparative effecto of a) ryanodine, b) ryanodine plus caffeine and c) ryanodine plug sRTX-b on $\mathrm{Ca}^{2+}$ concentration-response curves obtalned in the anocoecygeus.

Figure 23 (a, b and c) Comparative effects of a) ryanodine,

b) ryanodine plus caffelne and c) ryanodine plus $\mathrm{ET}-1$ on $\mathrm{Ca}^{2+}$ concentration-response curves obtained in the anococcygeus.

Figure $24(a, b$ and $c)$

Comparative effects of a) ryanodine, b) ryanodine plus caffeine and

c) ryanodine plus sRTX-b on $\mathrm{Ca}^{2+}$ concentration-responge curves obtalned in the aorta.

Figure 25 (a, b and c)

comparative effecta of a) ryanodine,

b) ryanodine plus caf gelne and

c) ryanodine plus $\mathrm{ET}-1$ on $\mathrm{Ca}^{2+}$ concentration-responge curves obtained in the aorta.

Figure 26 (a, b and c) Effect of a) $E T-1, b) \operatorname{sRT} X-b$ and c) NE on Bay K 8644 concentsationresponse curve obtained in anococcygeus.

Illustration of a concentration-independent response of the anococcygeus( a), in contrast to the concentration-dependent response of the aorta (b), to Bay K 8644 .

Figure 28 (a, b and c) Effects of tho presence a) $\mathrm{ET}-1$, b) SRTX-b and, NE on Bay K 8644 concentration-response curves obtalned in the aorta.

Figure 29 (a, b and c) Ef fect of indomethacin on the $\mathrm{Ca}^{2 *}$ concentrat Lon-regponse curves obtained 


\section{xili}

in the anococcygeus in the presence of

a) $\mathrm{BT}-1, \mathrm{~b}$ ) SRTX-b and e) NE.

Figure 30 (a, b and c)

Figure 31 (a, b and c)

Figure $32(a, b$ and $c)$

Figure 33 (a and b)

Figure $34(a$ and $b)$
Effect of indomethacin on $\mathrm{Ca}^{2+}$

concentration-response curves obtained in the aorta in the presence of

a) $\mathrm{ET}-1$, b) SRTX-b and c) NE.

150

Effect of NDGA on $\mathrm{Ca}^{2+}$ concentrationresponse curves obtained in the anococcygeus in the presence of

a) $a T-1, b) S R T X-b$ and c) NE.

154

Effect of NDGA on $\mathrm{Ca}^{2+}$ concentrationresponse curves obtained in the aorta in the pregence of a) ET-1, b) SRTX-b and c) $\mathrm{NE}$.

a) Effect of NDGA on agonist concentrationresponse curves in the anococcygeus to :1) $\mathrm{ET}-1$, ii) $\mathrm{NE}$ and iii) $\mathrm{Ca}^{2+}$ concentrationresponse curves in the presence of $50 \mathrm{mM} \mathrm{k}$. b) Effect of NDGA on agoniat concentrationresponse curves in the anococcygeus to :1) SRTX $\rightarrow b$, 11) $\mathrm{NE}$ and 1i1) $\mathrm{Ca}^{2+}$ concentrationresponse curves in the presence of $50 \mathrm{mM} \mathrm{k} \mathrm{K}^{+}$.

a) Effect of NDGA on agonist concentrationresponse curves in the aorta to :-

1) $\mathrm{ET}-1$, 11) $\mathrm{NE}$ and iii) $\mathrm{Ca}^{2+}$ concentrationresponse curves in the presence of $50 \mathrm{mM} \mathrm{k} \mathrm{K}^{+}$.

b) Ef fect of NDGA on agonist concentrationresponse curves in the aorta to :1) SRTX-b, 11) $\mathrm{NE}$ and 1i1) $\mathrm{Ca}^{2+}$ concentrationresponse curves in the presence of $50 \mathrm{mM} \mathrm{k} \mathrm{K}^{+}$.

Figure 35 (a, b, c and d) Ef fect of SRTX-b and ET-1 on concentration-response curves to $\mathrm{VE}$ and $\mathrm{XCL}$ in the anocoscygeus :-

a) SRTX-b, b) ET-1 of fects on NE concentration-response curves; c) SRTX-b, d) ET-1 ef fects on KCL concentration-responge curves.

Figure $36(a, b, c$ and d) Ef fect of SRTX-b and ET-1 on concentration-response curves to $\mathrm{NE}$ and $\mathrm{KCL}$ in the aorta :- 
$x i v$

a) SRTX-b, b) ET-1 effecta on NE concentration-response curves;

c) SRTX-b, d) BT-1 effects on KCL

concentration-response curves.

Figure 37 schematic summary of cell gignalling processes in smooth muacle activated by $\mathrm{ET}-1$, SRTX-b and $\mathrm{NE}$. 


\section{IIST OF ABBREVIATIONS}

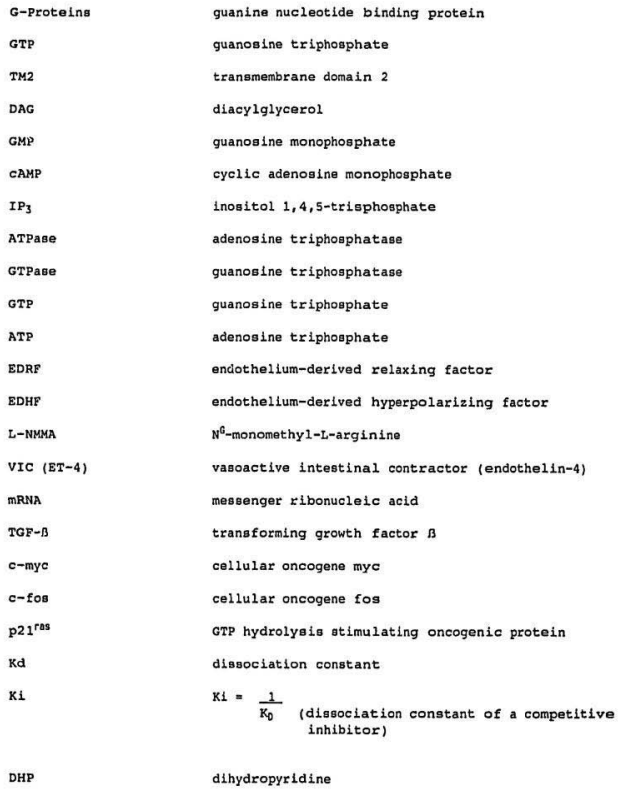

DHP 
xvi

NE

L.v.

AvP

$\mathrm{PGH}_{2}$

MRV

NEP

AnOVA

CICR (Sa)

$\operatorname{IICR}(S B)$

EDCF

PA

$\mathrm{PO}_{4}{ }^{3-}$

PLC

$\mathrm{PLA}_{2}$

NDGA

BT-1

sRTX-b

PC

vocc

SHR

$\mathrm{PIP}_{2}$

$\mathrm{PGI}_{2}$

c

A

v

I norepinephrine

intravenous

arginine vasopresain

Prostaglandin $\mathrm{H}_{2}$

mesenteric reshtance vessels

neutral endopeptidase

Analysis of variance (one-way)

calclum induced calcium release (a stores)

inositol trisphosphate induced caleium release ( $B$ stores)

endothelium-derived contracting factor

phosphatidic acid

phosphate

phoopholipase C

phospholipase $\mathrm{A}_{2}$

nordihydrogualaretic acid

endothelin-1

sarafotoxin-b

phosphatidylcholtne

voltage operated $\mathrm{Ca}^{2+}$-channel

opontaneously hypertensive rat

phosphatidylinositol 1,4-biaphoephate

Prostaglandin $I_{2}$

glycine (Gly)

alanlne (Ala)

valine (Val)

leucine (Leu) 
xvii

I

F

p

s

T

c

M

พ

$Y$

D

N

E

Q

K

R

H

$\mathrm{Rb}^{+}$

$s r^{2+}$

THM
Loleucine (I10)

phenylalanine (Phe)

proline (Pro)

Berine (Ser)

threonine (Thr)

cysteine (Cys)

methionine (Met)

tryptophan (Trp)

tyrosine (Tyr)

aspartic acid (Asp)

asparagine (Asn)

glutamic acid (Glu)

glutamine (Gln)

lysine (Lys)

arginine (Arg)

histldine (His)

Rubidium

strontium

Tunica muscularis mucosa 


\section{Chapier 1}

\section{INTRODUCTION}

\subsection{Vascular tone.}

The control of vaseular tone has continued to be an enigma to physicians and medical researchers alike, the plurality of antihypertenslves attest to this. Whatever its cause, and theortes abound, the characterietic hemodynamic feature of hypertension is a sustained elevation in total peripheral vascular resistance, with variable cardlac output (Lund-Johansen, 1977). Control of resistance and capacitance functions in perlpheral elreulation has been shown to be dependent on the tone of vascular mooth muscle (Meliander and Johansson, 1968). Vasculax tone is harmoniously controlled at various levels; extrinsically by neural and humoral inputs and intrinsically by the properties of structural components of the smooth muscle, Consequently, hypertension may be vlewed as a fallure of clrculatory regulation by one or more of these mechanieme (Brody et al., 1980). This view is not ohared by Folkow (1990) who emphasizes that structural changes of resistance vessels are the key site of disturbance in essential hypertension. Nonetheless, considerable evidence points to alterations, at the cellular level, in the regulation of vascular tone as at least a contributing factor to the etiology of hypertension (Mulvany, 1989; Triggle, 1984). Thus, studles of the varlous influences that can affect the level of vascular amooth muscle tone are central to furthering our understanding of not only normal control processes but also changes that may prove to be the basis for hypertenal Since this thesis concerns the pharmacology of a famLly of potent vasoconstrictor peptides, the endothelins, the introduction will focus on 
processes that regulate vascular tone. Thus, it is apparent that vascular amooth muscle is exposed to a wide array of stimuli ranging from mechanical to chemical, which may be excitatory or inhibitory, and that vascular tone at any point in time is the algebraic sur of responses to these inputs. Most, If not all, of these events or stimuli are mediated by receptor activation, gubseguent aignal transduction and resultant physiologic response which, in this case, would be contraction or relaxation.

Receptors for neurotransmitters such as norepinephrine and acetylcholine are no longer abstract concepts as it has become posgible to biochemically nolubilize and isolate them and, with molecular biological techniques, determine their amino acid sequence. We now know that these receptorg are membrane proteins with diatinct configurations. The wide array of stimuli earlier mentioned arrive at the receptor either as mechanical signals, such as atretch, which in the intact organlesi may be a rise in intravascular distending pressure, or electrical stimull applied directly or induced by chemicals (e.g. potassium chloride or by a wide variety of neurotransmittero ranging from simple amino acids, such as glycine, to polypeptide hormones and the well known neurotransmitters acetylcholine and catecholamines).

The first step of receptor activation involves the binding of a given 1igand to its receptor with a resultant conformational change. The conformational change in the membrane receptor induces a high affinity state for agonist in the presence of guanine nucleotides (Cassel and selinger, 1976). It was later ghown that the guanine nucleotides were bound to certain proteins now simply referred to as G-proteins or guanine nucleotide binding proteins (Detean et al., 1980). It is becoming clear that plasma membrane receptors belong to structurally related families such as the $G$ protein 
coupled receptors or 1 igand-gated ion channels (schofield and Abbott, 1989). Indeed, nine different genes have been found to code for $G$ proteing (Freissmuth et al., 1989). The G-protein 18 a trimer made up of $\alpha, B$ and $\gamma$ gubunits which are necessary for interaction with receptor, but the dissociation of subunits is required for activation. There appears to be a consensus of opinion that the $\alpha$ subunit, which binds the activated receptor and GTP, effects the transduction process to the amplifier enzyme system in an agoniat-dependent manner (see Figure 1). The pregence and prepunderance of these amplifier enyzmes appear to be tissue dependent and thelr activation is agoniet dependent. Thus, the activation of adenylate cyclage and the resultant increase in caMP in cardiac muscle leads to increased contractile abllity whereas in gmooth muscle the increase in caMp leads to relaxation (Sharma and Bhalla, 1989).

The second messengers produced by the amplifier enzyme phospholipase C $v i z, D A G$ and $I P_{3}$, act interdependent $l_{y}$. Inositol 1,4,5-trisphosphate (IP3) induces the cell to moblilze gt111 another messenger, calclum long ( $\mathrm{Ca}^{2 *}$ ) from endoplasmic (sarcoplasmic) reticulum or calcisome depending on the cell (Berridge, 1985). In general, the second messengers bind to regulatory components of a protein kinase, an enzyme that activates or inhibits a cellular response such as contraction or gecretion by adding phosphoryl $\left(\mathrm{PO}_{3}{ }^{2-}\right.$ ) groups to particular proteins. Calcium binds to a family of proteins Including ealmodulin and troponin C. In turn, calcium-calmodulin activates a protein kinase. Activation of protein kinase $C$ (PKC) requires $\mathrm{Ca}^{2+}$ and phosphatidylserine, and dlacylglycerol increases the affinity of PKC for these activators. Protein kinase C selectively phosphorylates serine and threonine residues. It is now generally belleved that the major mechanisi of 
Figure 1: Schemat1c representation of receptor activation by agonist and some post receptor events.
A, agonfst; $R$, receptor; $\alpha, B, \gamma$, subunits of GTP binding protein; GTP, guanosine triphosphate; PLA, phospholipage $A_{2}$ PLC, phospholipase C; PIP 2 , phosphatidylinositol 4,5-bisphosphate; DAG, diacylglycerol; PKC, proteln kinase C; PC, phosphatidylcholine; PA, phosphatidic acid; IP, inositol 1,4,5-trisphosphate; SR, sarcoplasmic reticulum. 


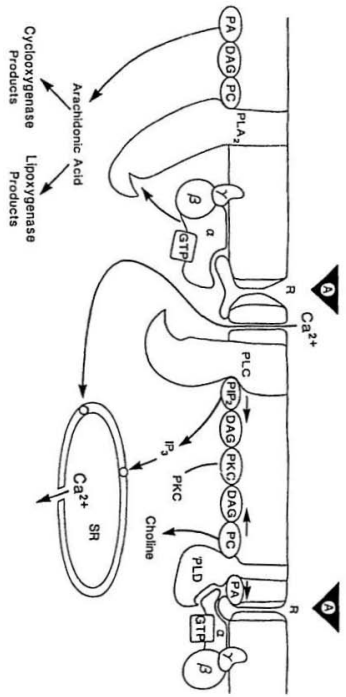


regulation of contraction is through binding of $\mathrm{Ca}^{2+}$ to calmodulin and of the $\mathrm{Ca}^{2+}$-calmodulin complex to myosin light chain kinase, followed by myosin light chain phoophorylation that permits activation of myosin ATPase by actin (Kamm and Stull, 1985).

The initiation of contraction is brought about by a transient rise in cytosollc salclum when a cell is stimulated by an external signal. The $\mathrm{Ca}^{2+}$ enters through channels that are selective or relatively selective for this fon and simultaneous release from intracellular stores aids in the transient rise of cytosolic calcium. Sone channels are voltage-dependent and open when the action of a neurotranamitter leads to changed in the tranamembrane voltage differences that normally exist across the membrane; and others open when a hormone or neurotransmitter interacte with a cell surface receptor that is linked to channels known as receptor operated $\mathrm{Ca}^{2+}$-channels (Carafoli and Penniston, 1985). This rice in calcium is thought to be responsible for the transient or initial contraction resulting from the cascade of kinase activation leading to muscle contraction with relaxation resulting when a fall of cytosolle calcium concentration occurs. The on/off switch sole for $\mathrm{Ca}^{2+}$ may be overridden during a sugtained contraction (Rasmussen, 1989). During a sustained or tonle contraction, the intracellular $\mathrm{Ca}^{2+}$ concentration does $r$ ise as predicted but only transiently and then it falls back to basal levels within a minute or so even though active tension is maintained (Morgan and Morgan, 1984; Silver and Stull, 1982). Rasmusgen (1986) postulates that, during the sustained phase, contraction is dependent on extracellular $\mathrm{Ca}^{2+}$ in spite of the fact that its concentration is no longer elevated. During a suatained contraction, it appears that a specific $\mathrm{Ca}^{2+}$-sensitive enzyme, protein kinase c, becomes associated with the plasma membrane and fin this 
location is responsive to hornonally induced changes in the rate of plasma membrane $\mathrm{Ca}^{2+}$ influx rather than changes in $\mathrm{Ca}^{2+}$ concentration (Shearman ot al.,1989). Thus, it seems that there is altersd sengitivity of contractle proteins in the presence of activated protein kinase $\mathrm{c}$ at basal $\mathrm{Ca}^{2+}$ levels. The transient rise in intracellular calcium and DAG together cause protein kinase $\mathrm{C}$ to associate with plasma membrans. Unlike IP, DAC remains In the membrane; as long as the DAG content of the membrane remalns high, protein kinase C remains associated with the membrane (Ragmusgen, 1989). Rasmussen (1989) thus concluded that the transient release of $\mathrm{Ca}^{2+}$ from calcisomes and the migration of PKC from cytosol to plasma membrane are the hallmark of the initial stages of a sustained cellular response to an extracellular signal. However, the recent finding by sunako et al. (1990) that sustained high levels of diacylglycerol (DAG) do not directly correlate with Increasing or sustalned tension questions the singular role of DAG In the austained cellular response. In a comparison of measured levels of DAG In response to angiotens In II and endothelin-1, sunako et al. (1990) observed that a sustained high level of DAG induced by angiotensin was accompanied by a losg of tension whereas a decrease in the level of DAG was assoclated with increasing tension for endothelin-1.

The key feature of the Rasmussen model (Rasmusgen, 1989) of austained cellular response is the operation of two temporally distinct branches of the calcium messenger-system: a calmodulin branch active during the Initlal phase of response, in which the transient, $\mathrm{IP}_{3}$-induced $\mathrm{rise}$ in the cytosolic concentration of calcium acts on calmodulin-dependent proteln kinases to olter the phosphorylation of one subset of cellular proteins, and a PKC branch, in which the rise in calcium concentration in the submembrane domain 
acts on plasma membrane-associated PKC to alter the phosphorylation of a different gubset of cellular proteins involved in mediating the second, gustained phase of cellular response. This model further postulates that the physical distance between the plasna membrane location of activated PKC and the contractile proteins can be bridged by klnase cascades, one phosphorylating the other until contractile protein phosphorylation is achieved. The evidence in support of this model is that there is phosphorylation of two high molecular-weight proteins assoclated with smooth muscle contraction, desmin and caldesmon, which are localized in domains of the cell that are remote from the site of PKC action. In conclusion, Rasmussen noted that $\mathrm{Ca}^{2+}$ appears to operate as an intracellular messenger only during brief cellular responses or during the initial phases of sustained responses. Furthermore, a sustained response phase is dependent on a calclum signal generated in a restricted region of the cell membrane by an 1ncrease in rate of $\mathrm{Ca}^{2+} \mathrm{cy}=1 \mathrm{ing}$ across the membrane. Rasmussen maintaing that this aubmembrane calcium signal acts on calcium sensitive, plasma membrane-asaociated transducers to generate other signals. In essence, it is the messengers generated by the transducers, rather than calcium, that convey information from the cell surface to the coll interior. It is, however, apparent that much remains to be learned about the kinase zascades and the separate control of calcium cyeling and the plasma membrane association of PKc.

The plart alkaloid ryanodine has proved to be a useful probe for studying the roles of intracellular $\mathrm{Ca}^{2+}$ stores in initlating and sustaining muscle contraction (Jenden and Fairhurst, 1969). Most studies with ryanodine have involved Investigattons of Intracellular calcium storeg in skeletal and 
heart muscle (Besch, 1985; Lakatta et al., 1985; Sutko et al., 1985). More recently, Hwang and van Breemen (1987) have used ryanodine to examine Intracellular calcium stores in vascular smooth muscle. Caffeine has also been used In simllar studies (Leljten and van Breemen, 1984; sato et al., 1988). The extent to which the different calcium stores in the plasma membrane, sarcoplasmic reticulum and mitochondria of smooth muscle can be examined may help to elucidate the nature of the defect in $\mathrm{Ca}^{2+}$ alluded to in the studies by Shibata et al. (1975) and Kwan (1985) concerning changes in vascular smooth muscle function in hypertension.

Recent studies of endothelial-vascular smooth mucle interaction, howeves. suggest that changes in endothelial cell function may be of importance (Lisscher, 1990). The endothelfum forms an interface between cfrculating humoral agents and vascular smooth muscle which, for a long time was though: to serve only barrier functiong with the primary role of regulating the passage of varied substances between blood and tissues. The endothelium can also act as an endorrine organ in response to stimull and release prostaglandins, growth factors, relaxing factora and constricting substances, all of which have potential to modulate growth or reactivity of the underlying smooth muscle (Loeb and Peach, 1989).

An increase in blood pressure has the potentlal to alter many of the normal smooth muscle-endothelium reactions. Endothelial damage potentlally can impair important metabolic functions of the endothellal cell layer, thereby allowing exposure of the vessel wall to factors with which it normally does not come into contact (Loeb and Peach,1989). Pressure Lnduced changes also have the potential to alter the ability of the endothelium to release smooth muscle conditioning factors or to alter respongiveness of the 
gmooth muscle cells and vascular nerve terminals to substances or signals derived from the endothelium (Loeb and Peach, 1989). Golby and Beilin (1972) firgt proposed that endothelial injury resulted from an elevation in blood pressure. Subsequently, Huttner et a1. (1973) clearly demonstrated that endothelial permeability to horgeradish peroxidase and fexritin was increased In animals made hypertensive by either aortic coarctation or catecholamine infusion when compared to normotensive controls. The changes in permeability were associated with structural changes in the endothelium such as opening of itercellular gaps and nuclear pinching. As permeability increases, the access of vasoactive blood borne substances to smooth muscle is also enhanced (Loeb and Peach, 1989).

In addition to acting as a barrier to blood borne vasoactive agents, either as an actual physical barrier or as a metabolic barrier, the endothellum can synthesize and release compounds which can increase as well as decrease blood pressure(see review by Lüscher,1990), Although the ultimate control of blood pressure is the result of a myriad of competing signals, an alteration in the synthesis, storage, release or response to locally acting, tonically released endothelium-derived substances could prove catastrophlc to the dellcate balance of feedback loops controlling vasoactive hormone release, neuronal activity levels and central reflexes. The homeostatic mechanisms normally controlling blood pressure could be disturbed enough to produce or exacerbate hypertension (Loeb and Peach, 1989). It is thus apparent that studies of the pharmacology of the factors released from endothelial cells may prove to be profitable with respect to furthering our undergtanding of the cellular basis for the Increased peripheral resistance associated with essential hypertension. 


\subsection{Endothelium-derived relaxing factors.}

As noted above, certain functions have been ascribed to the endotholium but the non-recognition of the crucial role it could play in modulating the functions of vascular amooth muscle, in spite of its strategic anatomical location is, perhaps, surprising. Fortuitoug as some may claim, it took the keen sense of observation of Furchgott and zawadzki (1980) to indleate to vascular physiologists and pharmacologists that there in more to endothellum than just a physical barrier.

The ability of acetylcholine and other muscarinle agoniata to produce marked vasodilatation in various vascular beds in vivo was well established many years ago (see review by Furchgott, 1988). It has alao boen demonstrated that acetylcholine and other muscarinic agonists could produce relaxation of Lolated perfused or guperfused blood veseels contracted by stimulation of adrenergic nerves (Rand and Varma, 1970; steinsland ot al., 1973; Vanhoutte, 1974). Thus, it was to be expected that muscarinie agoniats should produce relaxation of spontaneous or drug-induced contractions of 10olated preparations of blood vessels (bee review by Furchgott, 1988). This was not the case unt11 1980 when Furchgott and Zawadzk1 noted that the nonrelaxation of their helical strip preparations was due to the dissection technique which denuded the vessels of endothelium. When this procedure was modified so that damage to the endothellal cell layer was avoided, the resulting helical strips exhibited good relaxation in responge to low concentrations of acetylcholine. It was demonstrated by 1 light microscopy, and 2180 by ecanning electron microscopy (Furchgott ot al., 1981), that there is a direct relationship between the extent of relaxation of aortic preparations by acetyleholine and the reaction of endothollal cells retained. 
One hypothesis to explain the obligatory role of endothelial celis in the relixation of rabbit aorta by acetylcholine was that this agent, acting on the mugcarinic receptor in these cells, stimulated them to release a subotance that, in turn, acto on smooth muscle cella in the vessel media to activate relaxation. In testing this hypothesis, cascade perfusion and auperfusion procedures have yielded positive results (Griffith et al., 1984; Foratermann ot a1., 1984, Rubanyi et al., 1985) and the "sandwich" mounts of Furchgott and zawadzkl (1980) have been conslstently positive. Thus was born the concept of endothellum-derived relaxing factor (BDRF). The nature of EDRF has been a subject of controvergy ranging from the number of posalble EDRFs to chemical characterization. There veem to be two candidates so far for the relaxation induced by endothellum. One of them has been named endothelium-derived relaxing factor (EDRF: Furohgott zawadzki, 1980) and the other has been named endothelium-derived hyperpolarizing factor (BDHF) (Taylor ot al., 1988). EDRF is vaid to increase tisese cyclic GMP concentrations and produces an electrically-gilent relaxation, whereas EDHF produces trangient hyperpolarization associated with opening of ${ }^{86}$ Rb-permeable $\mathrm{K}^{+}$-channels. This event may serve to initlate relaxation processes and to cloge any open voltage dependent Ca-channels (Taylor et al., 1988). The Cindlings of Feletou and Vanhoutte, 1988; Chen and Suzuk1, 1990; M11ler and Vanhoutto (1989) confirm this postulate. Marshall and Kontos (1990), in a review of endothellum-derived relaxing factors, have noted that geveral auggestiona, including those that EDR is a product of lipoxygenase metabolism of arachldonate (Peach et al., 1985), a product of cytochrome p450 oxygenase (Singer et al., 1984) or a carbonyl-containing compound (Griffith et al, 1984), have been diaproved. Most recently, evidence has 
been gathered suggesting that EDRF generated by acetylcholine in blood vessels, and by bradykinin in cultured ondothelial cells, is nitric oxide (Palmer et al., 1987; Ignarro et al., 1987). This view is gupported by phamacological similarities between nitric oxide and EDRF (Ignarro ot al., 1987), by inhibition of action of both nitric oxide and EDRF by various pharmacological blocking agents such as hemoglobin and methylene blue (Martin et al., 1984), and inhibition of production of both nitric oxide and EDRF from arginine by $\mathrm{N}^{6}$-monomethyl-L-arginine (L-NMMA) (Rees et al., 1989). In spite of such compelling data, there has been no unanimity of opinion. Some investigators have been able to identify pharmacological differences between nitric oxide and EDRF (Long ot al., 1987); other investigators have shown that the anount of nitric oxide released by acetyleholine from vessels or by bradykinin from endothellal cells is not sufficlent to explain the observed vasodilation (Myers et al., 1989); finally, other investigators have been unable to find release of nitric oxide by electron-spin resonance techniques coupled with the uve of spin trapa (Rubanyi et al., 1989). That EDRF may be a nitric oxide containing compound that is much more active In inducing vasodilation than nitric oxide itself has been suggested. Nitrosothiols have propertieg that render them appropriate candidates for this purpose (Myers et al., 1989; Wei and Kontos, 1990).

The obligatory role of endothellal cells for the manifestation of acetylcholine-induced relaxation extends to many arteries in a variety of species including dog, cat, guinea-plg and humans (Furchgott and zawadzki, 1980; Furchgott et al., 1981; Cherry ot al., 1982), the unexplained exceptions being the basilar artery of the dog and coronary artery of the pig 
(Katugic et a1., 1984; shinokawa ot a1., 1987).

The endothelium-dependent responsiveness to acetylcholine (or to other vasoactive agenta) as noted by Vanhoutto (1989) is not fixed, as it can be modulated chronically by henodynamic variables or hornonal status (Miller et al., 1986; Crisclone et al., 1989). Chronic modulation by hemodynamic variables may explain why, in animals and in humans, the endothellumdependent responses to acetylcholine fand of the endothelium-dependent dilators) are considerably blunted in peripheral veins compared to arteries (De Mey and Vanhoutte, 1992). It is important to note that acetylcholine does not circulate in blood and In most tissues Innervated by cholinergic nerves, acetylcholinegterage, an enzyme that is remarkably effective in rapidly deotroying the cholinergic transmitter, id present. Hence, to date, no evidence has been obtained that acetylcholine released from cholinergic nerves can reach endothellal cells in amounts aufficient to evoke endotheliun-dependent relaxations. However, substances circulating in the blood would be potential candidates for triggering endothelium-dependent responses. Indeed, endothelial cells, at least in large blood vessels carrylng oxygenated blood, contain $a_{2}$-adrenergic receptors that, when activated, can evoke endothelium-dependent relaxation of the underlying amooth muscle (Coeks and Angus, 1983; Miller and Vanhoutte, 1985; Vanhoutte and Miller, 1989). Hence, it is 1ikely that $a_{2}$-adrenergic endotheliumdependent effects of catecholamines contribute to vasodilator effects in the coronary circulation or the eplanchnie bed (Vanhoutte, 1989).

Finally, it has been known for decades that, when flow increases through large arteries, dilatation ensues ("flow-induced vasodilatation") (see review by Vanhoutte, 1989). It is now egtablished that this phenomenon is 
endothelium-dependent and can be attributed to EDRF caused by an increase in shear stress. Whether this is secondary to release of autacold (acetylcholine, ATP, serotonin or gubstance P) by certain selective endothelial cells or to direct activation of all endothellal cells by ahear atress is uncertain (Vanhoutte, 1989).

\subsection{Contracting factors.}

While searching for possible heterogenelty of endothelium-dependent relaxation to acetylcholine, adenosine diphisphate, arachidonie acid and thrombin, it was discovered that endothellal cells, when exposed to certain stimuli, not only produced vascular dilator(s) (Furchgott, 1983, Vanhoutte et al., 1986), but also vasoconstrictors - so called endothellum-derlved contracting factor(B) (EDCE) (De Mey and Vanhoutte, 1982; 1983). At least two different types of EDCFs have been identified (Vanhoutte and Katusic, 1988). One type is a rapid onset, hypoxia induced, eyclooxygenase inhibitor resistant EDCF; a rapid relaxation ensues when normoxia returns. This substance is still unidentifled. The time course of action makes it unlikely that the endothelium-derived contracting factor(s) involved are peptides released from hypoxic endothelial cells (Rubany1 and Vanhoutte, 1985; Vanhoutte et al., 1989), since the response to hypoxia is faster than peptide induced contraction and can be prevented by a calcium ari,sgoniat. Indoed, endothelin is not stored in endothellal cells (Yanaglsawa et al., 1988b). A second type of EDCF is sensitive to cyclooxygenage inhibition, and ita release is induced by a variety of stimuli, including arachldonic acid, acetylcholine, calcimycin (A23187), sudden stretch in cerebral arterles of dog, aorta of (SHR) spontaneously hypertensive rat, canine systemic and pulmonary veins (Miller and Vanhoutte, 1985; Katuric et a1., 1987; De Mey and 
Vanhoutte, 1983). Recent gtudies (see Lüscher, 1990) suggest that an alteration in the production of the constrictor $\mathrm{PGH}_{2}$ may be a contributing factor to the Increase in the peripheral resigtance associated with essential hypertension. A third EDCF is the peptide endothelin, a factor originally associated with the supernatant of cultured endothellal cells which produces a long lasting contraction. The endothelin-induced contraction is very difficult to reverge and it is resitant to cyclooxygenase inhibition but is attenuated by trypoin (Cillesple et al., 1986; Yanagiaawa ot al., 1988a).

In canine sygtemic and pulmonary veins, arachidonic acid augmented contractions evoked by norepinephrine; the augmentation was not observed in preparations in which the endothelium had been mechanically removed (De Mey and Vanhoutte, 1982). This obgervation was the first demonstration that the presence of endothellal cells can augment, rather than depress, contractile regponse of loolated blood vessels. The facilitation by arachidonic acid of the respones of the endothelium of systemic and pulmonary veins was prevented by inhibitoro of the enzyme cyclooxygenase but not by inhibitorg of prostacyclin synthetase, thromboxane synthetase or lipoxygenase (Miller and Vanhoutte, 1985). These findings indicate that venous endothellal cellg could metabolize arachidonic acid into a vasoconstrictor prostanoid, other than prostacyelin and thromboxane $\mathrm{A}_{2}$.

Most recently, the fact that attempts to bioassay the endothelium-derived contracting factor released by acetylcholine have falled, indicates that a very labile substance such as an endoperoxide Intermedlate or oxygen-derived free radical must be involved or that the subgtance if only released towards the abluminal side of the blood vessel wall (LIscher, 1990). Scavengers of oxygen-derived radicalo, such as superoxide dismutase do provent the 
endothelium-dependent contractions to acetylcholine in the cerebral blood vessels but not in the rat thoracic aorta (Auch-Schwelk et al., 1989). It is pertinent to note that the rulaxation of perfuaed canine femoral artery by acetylcholine consists of transient and sustained components. The transient component is observed with lower concentrations of acetylcholine and appears to be caused by activation of endothelial $M_{1}$-muscarinic receptors; the sustained component is seen with higher concentrations of the cholinergic transmitter and can be attributed to stimulation of $\mathrm{M}_{2}$-muscarinic receptors (Rubanyl et al., 1987). The transient, but not the sustained, response ls Inhibited by quinacrine and metyrapone, which suggeat that the former io mediated by a metabolite of arachidonic acid (Rubanyi and Vanhoutte, 1987). conversely, high concentrations of catecholamines inhibit the sustained but not the transient phase of the response to acetylcholine (Rubanyl et al., 1985). The endothelium-dependent contractions to acetylcholine occur with higher concentrations of acetylcholine than those needed to release EDRF (LÜscher and Vanhoutte, 1986). Thus, with higher concentrations of acetylcholine, EDRF is still released, however, release of the contracting factor(s) by higher concentration of the cholinergic tranomitter blunta the relaxant effect with a preponderant contractile response.

The recent review by Lischer (1990) sums up the current trond of thought, notably that a contracting factor other than endothelin, namely prostaglandin $\mathrm{H}_{2}$, may be involved in defective endothelial cell function in hypertension. Nevertheless, a role for endothelin has not been ruled out.

\subsubsection{Endothelin.}

Evidence for a vasoconstrictor endothelial peptide came from studies on cultured bovine endothelial cells, whose aupernatant had contractile 
propertles on bovine pulmonary, pig and rabbit coronary arteries (0.Brien and MeMurtry, 1984; Hickey ot al., 1985; G1lleopie ot al., 1986). The existence of a new vasoconstriletor peptide synthesized by the endothelium was postulated after ruling out the possibility that anglotensin or substance $P$ could mediate those effects (C1Llesple ot al., 1986).

The contractile peptide was isolated and purifled from cultured cells of porcine aortic endothelium by Yanagisawa ot al. (1988a). Endothelin was identified as a 21-amino acid, potent vasoconstrictor peptide and since it was reported that there were at leagt three endothelin genes in the human genome, the products of its expression were designated ET-1, ET-2 and ET-3 (Inoue et al., 1989). More recently, ET-4 (vasoactive intestinal contractor - VIC) has been lsolated from the mouse (Saida ot a.,, 1989) and expressed predominantly in the intestine, raising the posgibility of tissue specific ET variants. ET-1 ia identical to the form originally isolated from poreine endothelial cells (Itoh et al., 1988), whereas the amino acld sequence of ET3 is identieal to that found in the rat genome (Yanagisawa et al,i 1988b; Inoue et al., 1989). Therefore, it was thought that many mammalian species, including pig, dog, rat and human produce the three isopeptides of the endothelin family (Yanagisawa and Masak1, 1989a, b).

\subsubsection{Regulation of syuthesis and release of endothelin.}

A peptide of 203 amino acids is the precurgor molecule for endothelins. These pro-hormones demonstrate species and isopeptide-specific differences in amino acid sequence (Simonson and Dunn, 1990a). In addition to containing the mature EF peptide, the prepro-precursors contain a cysteine-rich, ET-11ke region (15 residues) that is highly conserved (Yanagisawa et al., 1988a; Itoh et al, 1988). The biological significance of differences in amino acid 
gequence between the prepro apecies, and of the presence of an ET-11ke peptide within the prepro Br, are unclear.

In cultured endothelial cells, prepro ET-1 is proteolyt lcally cleaved to form a 38 (human)- or 39 (porcine)-amino acid big ET (shinmi at al., 1989). This is absequently procesged to mature ET-1 by the putative 'endothelin eonverting enzyme' (Yanaglsawa et al., 1988a). Yanagisawa and Masaki (1989a) have suggested that endoproteolysis may provide an Important site for pharmacologieal intervention.

It appears that vascular endothelial cellg do not produce ET-2 or ET-3; only ET-1, or lte mRNh, can be detected in endothelial cells in culture supernatant (Yanagisawa and Masak1, 1989a). The expression of ET-2 has not yet been convincingly demongtrated in any tisgue. ShinmL et al. (1989) have demonstrated that ET-3 immunoreactive material is present in porcine brain homogenate. In addition, endothelin and related peptides can be syntheslzed and secreted fxom renal epithellal cells (Shichiri et al. 1989) and integtinal cells (Salda et al. 1989) of non-endothelial origin.

Most recent studies (MacCumber ot al., 1989; Maccumber at al., 1990; Yoshizawa ot al., 1990) show that ET 1sopeptides are different Lally expreseed only in apecific tissues, which auggeat that tisau-specifie factors control the rate of ET gene expression. Above cited Invegtigators demonstrated transcripts for both prepro ET-1 and prepro ET-3 in adult rat lung, kidney, eye and brain, whereas both ET-3 and ET-1 were abundantly expressed in the lung. mRNA transcripte for VIC (ET-4) have been found in the murine intestinal tract (Salda et al., 1989). In the rat kidney, ET-1 was expressed predominantly in the medullary vasa recta (Maccumber ot al., 1989). The inabilizy to demonstrate ET-1 gene expression in some adult tissues could 
reflect the relative insensitivity of Northern analysis to detect rare transcript or poor hybridization of ET-1 and ET-3 probes with noncomplementary tissue specific ET isoforms (Simonson and Dunn, 1990a).

An important aspect of enclothelin biology is the failure to denonstrate, In situ, endothellum-dependent vasoconotriction mediated by endothelin. It has been speculated that ET-1 from endothelium is regulated at the level of! peptide synthesis but not at the level of the mechanisms of release (Yanaglawa and Maska1, 1989a, b). The induction of ET-1 mRNA and/or peptide by various chemical stimuli has been studied mainly in cultured endotholial celle. The growing 1 ist of physiological stimuli that can increase BT-1 production includes thrombin (Yanagisawa ot al., 1988a); transforming growth factor B (TGF-B) (Kurthari et al., 1989); angiotensin II (Emori et al., 1989); [Arg)vasopressin (Emori et al., 1989); fluid dynamic shear stress (Yoshlzumi et al., 1989). Thrombin, angiotensin II and vasopressin gtimulate phospholipase $\mathrm{C}$ activity in endothelial cells leading to the formation of the second messengers inositol 1,4,5-trisphosphate (which mobilizes $\mathrm{Ca}^{2+}$ from intracellular storage sites) and 1,2 diacylglycerol (which stimulates protein kinase C). Shear stress also increases intracellular free $\mathrm{Ca}^{2+}$ concentration in cultured endothelial cells, both by gtimulating the influx of extracellular $\mathrm{Ca}^{2+}$ and mobilizing intracellular $\mathrm{Ca}^{2+}$ (Ando et al., 1988). Indeed, ET-1 mRNA and peptide are also Induced by $\mathrm{Ca}^{2+}$ Lonophores and phorbol esters (Emorl et al., 1989; Yanaglsawa et al., 1989). These observations are consistent with the Idea that production of ET-1 in endothelial cells can both be regulated by intracellular $\mathrm{Ca}^{2+}$ and protein kinase $\mathrm{C}$ - that is, possibly by PI turnover olgnalling in endothelial cellg.

The 5' promoter region of human ET-1 gene contains several elements 
reaponsive to 12-0-tetradecanoylphorbol 13-acetate which are found in other genes that can be induced by phorbol est... (Inoue et al., 1989). It also contains the nuclear factor-1-binding elements that have recently been recognized to be involved in response to TGE-B. Whether these potential regulatory DNA elements in the ET-1 gene are actually involved in the regulation of ET-1 production by agents such as those 11 sted above w111 be determined by promoter mapping studiea. The lovel of ET-1 mRNA in endothellal cells may be controlled not only by transcriptional regulation but also by post trangcriptional regulation of mRNA degradation. Half-1ife studies using the transcription inhibitor actinomycin D have ravealed that ET-1 MPNA 1s extremely labile, having an intracellular half-life of about 15 minutes (Yanagisawa et al., 1989). This rapid degradation is specific for ET-1 mRNA, since B-actin mRNA has a much longer half-1ife $(10-20 \mathrm{~h})$ in the same cells. Both porcine and human ET-1 mRNA possess several 'AUUUA' sequences in the $3^{\prime}$ non-translated regions. These AU motifs have been recognized to be involved in highly selective mRNA destabllization and are found in mRWAs encoding certain tranglently expressed cytokines, growth factors and nuclear proto-oncogene products (usually involved in programing of cellular growth and differentiation). It is concelvable that ET-2 may also belong to this class of signal molecules.

\subsubsection{Pharmacological ef fects of endothelin.}

Endothelin has been described as the most potent vasoconstrictor known (Yanagisawa et al., 1988a). The contractile activity of the different

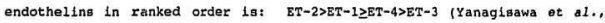
1989; Rodman ot a.l., 1989; Salda et al., 1989).

ET-1 provokes atrong sustained contractions in isolated vascular amcoth 
mugcle preparations in almost all animal species and vascular regions examined Including microvessels (Brain, 1989). Other vascular effects of ET1 include the stimulation of release of elcosanoids and enctothelium-dependent relaxing factor (EDRF) from perfused vascular beds (de Nucci et al., 1988). The additional finding that endothelin acts not only on vascular but non-vascular $t$ issues (Yanagisawa and Masaki, 1989b), has ralsed questions about itg role in the control of vascular tone. ET-1 has a wide spectrun of pharmacological effects on non-yascular tissues viz: contraction of airway (Uchida et al., 1988), intestinal smooth muscle (deNucel et al., 1988; Borges et al., 1989), uterine gmooth muscle (Borges et al., 1989; Eglen et al., 1989), cardiac chronotropic and inotropic actions (Ishikawa et al., 1988a, b) and atimulation of atrial natriuretic peptide release (Fukuda et al., 1988), inhibition of ouabain sensitive $\mathrm{Na}^{+} / \mathrm{K}^{+}$ATPase $(2 \theta i d e l$ et $21,1,1989)$ blockade of the antidiuretic effect of vasopressin in yivo (Goetz et al., 1988), modulation of catecholamine releage from sympathetic termini and adrenomedullar chromaffin cells (Tabuchl et al., 1989; Boarder and Mariott (1989), and the stimulation of aldosterone release in adrenal glomeruloga cells (Cozza et $=2 ., 1989$ ). Evidence suggestive of a neuromodulatory role has boen adduced (Jones at al., 1989, kokesl et al., 1989). The wide spectrum of target tissues and of species non-spectfielty imply that ET-1 might have wide ranging actions in diverse organs. In cultured mesangial cells (Badr et al., 1989; simonson et al., 1989), and vascular mooth muscle cells (Komuro et al., 1988), ET-1 is a potent mitogen and stimulates c-myc and $\mathrm{c}-\mathrm{fos}$ proto-oncogene expression resulting in hyperplasia, suggesting a posolble role for ET in vascular remodelling or atheroselerosis (simonson and Dunn; $1990 \mathrm{~b})$. 


\subsubsection{Homology between ET-1 and SRTX-b.}

Perhaps the nost perplexing finding has been the discovery of atrong identity between endothelins and aarafotoxin. Sarafotoxins, as characterized by Kochva et al. (1982), Weiser et al. (1984) and Takasak1 et a 1. (1988), are potent vasoconstrictor, cardlotoxic peptides from the venom of the burrowing asp (Atractaspis engaddensie), which cause severe coronary apasm and sco changes in snake bite victims. The similarity between these two peptides led Graur et al. (1988/1989) to examine their evolutionary trends, and Kloog and Sokolovsky (1989) have hypothesized that the biological activity of endothelin and earafotoxin are mediated $v i a$ a commen receptor. Indeed, they suggest that endothelins are endogenous IIgands for 'sarafotoxin receptorg' (SRTX receptors).

Sarafotoxins (SRTX-a, $-b$ and $-c$ ) and more recently -d (Bdolah et al., 1989) are a group of 21-amino acid residue cardiotoxic peptides Lsolated from the venom of Atractaspis engaddensis, whlch are rlch in cysteine and ohow sequence Ldentity to the mammalian endothelins ET-1, ET-2, ET-3 and ET-4. Eight naturally occurring peptides of the endothelin/aarafotoxin 'family' are now known (Fig. 2). All eight peptides contain 21 amino aclds whlch poesese Cys1, Cys3, Cys11 and Cyol5 reaidues, with disulfide bonds between Cys 3 and Cys11 and between Cys1 and Cys15 (Yanagleawa et al., 1988b, Takasaki et al., 1988). Reduction of the disulfide bonds of the SRTKs (Kloog et al., 1988), and of the endothelins (Kimura ef al., 1988), regults in a marked loga of binding and activity. Also common to these peptides is the hydrophobic carboxyl terminal tall HLB16-Trp21. Cleavage of Irp21 from ET-1 regulted in marked loss of vasoconstrictive ability (Kimura et al., 1988). Moreover, even though Glu17 and Val 19 of SRTX peptides are roplaced by Leul7 and Ile19 
respectively in endothelin peptides, the size and hydrophobic nature of the carboxy terminal tall are preserved. This replacement, however, appeara to be of little functional significance. For example, ${ }^{125}$ I-iodinated SRTX-b and ET-1 pos-ess indistinguishable binding properties and both stimulate PI (phosphatidyl inositide) hydrolyais in various regione of the rat brain and also In the atrium (Ambar et al., 1989). SRTX-b and ET-1 also exert almost identical effects on the cardiovascular gystem, namely coronary vasoconstriction, which is manifeated electrocardiographically in mice by elevation of S-T segment, induction of atrioventricular block and induction of positive inotropic and chronotropic effects (Yanagisawa et al., 1988a, Takasakl et al., 1988; Wollberg et al., 1988; Ru Hu et al., 1988; Ishikawa ot al., 1988a, b). Furthermore, cross-desensitization between ET-1 and SRTX-b Induced changes in phosphoinositide turnover in neurons has also been demonstrated (Lin et al, , 1989).

It is also interesting to note that in all endothelln/sRTX peptides, the $\mathrm{N}$-terminal sequence is Cy 1-Ser2/Thr2-Cyg3, SRTX-a, SRTX-b, ET-1, ET-2 and ET-4 (VIC) contain Ser2, while SRTX-c, SRTX-d and ET-3 contain Thr2. Takasakl ot al. (1988) argue that it seems unlikely that the lower toxicity of the latter three peptides compared to the former, and the vasodilatory activity of both SRTX-c and ET-3, are due to substitution of the threonine for serine in position 2 on the grounds that the properties of these two residues are rather oimilar. Thue, the most important differences between the various peptides of endothelin/sarafotoxin ' $f$ amily' reside within the sequence of the 1nner loop Cys3-Cyo11. All the peptides possess Glu10, and, except for SRTX-C, they have Asp8-Lys9. Therefore, the sequence at position 4-7 represents the variable region of the endothelin/SRTX peptide 'family' 
(Kloog and Sokolovsky, 1989). Thus, unlike the 'conatant' C-terminal tall of these peptides, their $w$-terminal sequences are variable. Another interesting difference between the various endothelin/SRTX peptides involves their net charges which appear to derive from variations in the loop created by their disulfide bonds. For instance, SRTX-a and SRTX-b each have two positive and three negative charges and $\mathrm{ET}-1$ and $\mathrm{ET}-2$, with one positive and two negative charges would all have a net charge of -1 within the loop; SRTX-c (with four negative charges) would have a net charge of -4 , and ET-3 (with two positive and two negative charges) would have a net charge of 0 . AB SRTK-b and ET-1 have similar vasoconstrictive and cardiotoxic effects, which are differont from those of SRTX-C and ET-3, it seems that an overall net change of -1 within the cys3-Cys11 loop 18 required for blological activity (Kloog and Sokolovaky, 1989). The absence of this aingle net charge in SRTX-c and ET-3 is, aside from their common Cys1-Thr2-Cyв3, another common feature of these two peptides which may contribute to their vasodilatory activity. However, the marked difference between the Intraloop charges of SRTX-c $(-4)$ and ET-3 (0) may not explain the differences in potencies and/or mechanism of binding, and second messenger systems utilized by SRTX-C and ET-3 versus ET-1 or SRTXb (Kloog and Sokolovaky, 1989). It should be streased that SRTX-d differa from SRTX-b in two substitutions, which apparently do not affect binding in rabbit aorta, but do result in considerably lower lethality and vasoconstrictor potency ( $E C_{S O}$ values of $90 \mathrm{nM}$ and $5 \mathrm{nM}$, respectively; Bdolah et a1., 1989). From the functional point of view it is interesting that SRTX-c and SRTX-d are the least toxic. Altholgh a lower binding affinity to heart and brain membranes, and lower phosphoinositide hydrolyaia and vasoconstricting activities have been claimed for SRTX-c (Takasaki ot al., 
1988; Kloog et al., 1988), SRTX-d has been shown to have similar binding characterlatics to SRTX-b but less efficacy as a vasoconstrictor (Bdolah et al., 1989). According to Graur ot al. (1988/1989), the suggestion that the c-terminal 'tall' is esgential for vasoconstrictor activity (Yanagisawa et al., 1988b) seems less likely as this tall differs between the two groups (mammal versus snake), but it is virtually identical within each group with the exeeption of SRTX-d whIch hăs an ET-11ke tall. For instance, SRTX-b and ET-1 are both potent vasoconstrictors, and differ in their c-terminal 'tails', while SRTX-b and SRTX-c on the one hand, and ET-1 and ET-3 on the other, which have gimilay taild differ in their vasoconstricting powers by an order of magnitude (Yanagisawa et al., 1988b; Wollberg et a1., 1988).

\subsubsection{Endothelin and sarafotoxin receptors.}

The existence of four encothelin peptides also raises the possibility of existence of multiple endothelin receptor subtypes (Yanagisawa and Masaki, 1989b; Saida et al., 1989). However, in cultured rat aortic mooth mugcle cells, a single class of saturable, high affinity binding sites for $\left({ }^{125} \mathrm{~T}\right] \mathrm{ET}-1$ has been described (Hirata ot al., 1988b). There is no unanimity in classea or subtypes of receptors; thus watanabe et al.(1989) have defined two distinct typea of ET receptors on chick cardiac membranes. Kloog ot al. (1989), using homogenates of rat atria, aorta, uterus, cerebellum, caudate and putamen, indicated heterogeneity of $\mathrm{Er} / \mathrm{SRTX}$ receptor and adduced evidence for three receptor subtypes. More than one receptor has been proposed in blood vessels: a receptor with high affinity for ET-1 may mediate the vasoconstrictor response in vascular smooth muscle cells, whereas a receptor with higher affinity for ET-3 may be involved in the endothelin-induced release of BDRF from endothellal cells. Blnding studies with synthetic 
sarafotoxin suggest the existence of a heterogeneous population of vascular receptors for endotheling and garafotoxing (Hirata et al, 1989) wince the $K_{1}$ value for SRTX is apparently greater than the apparent $x_{d}$ value for the vascular ET receptora. Furthermore, Ambar et a 1 . (1989) have demonatrated marked differences in the affinitieg of ${ }^{125}$ I-SRTX for its bindlng 8 ites in various tisgues of the rat. Activation of endothelin receptors is associatod with an increase of phosphoinositide turnover except in cultured vasular smooth muscle cells (Hirata et al., 1988b), suggesting the existence of a speciflo recoptor-phospholipase C syetem. Thle system can aleo be stimulated equally by sarafotoxins (Iin et aI, 1989; Kloog and Sokolovsky, 1989; Hirata ot a., 1989). The fact that stimulation of phospholipase c by ET-1 in rat aortic cella involveg a pertusais toxin-ingensitive G-proteln allows for the speculation that the roceptorg for endothelin belong to a G-protein coupled superfamily (Yanagisawa and Masakl, 1989a). Furthermore, Tabrizchi and Triggle (1990) have provided in vivo evidence from pithed rats that, in vascular smooth muscle, a component of the response to ET results from activation of a pertuasis toxin-gensitive G-protein that Lo coupled to a receptor operated calcium channel and/or non-speciflc cation channel.

Autoradiographic studies have demonstrated the existence of endothelin receptors not only in vascular tissue, but also in rat brain, kidney, lung, adrenal gland and intestine (Jones et al., 1989; Kokesi et al., 1989). Long lasting effects of endothelin appear to be directly related to the nature of the interaction with the receptor(a)and. Thus, the dissociation of radiolabelled endothelin has been shown be very slow, with 858 of the Inltial cell-bound radioactivity remalning after 2 hourg (hirata ot a $1 ., 1988$ b). Galron et a1. (1989) have studied ET-1 and ET-3, sRTX-b and SRTX-c 
binding in intact cells and homogenates of rat heart myocytes and have demonotrated higher affinities for $\mathrm{BT}-1$ and SRTX-b than $\mathrm{ET}-3$ and SRTX-c. with cross-1inking techniques Sugiura et al. (1989) were also able to distinguigh ET-binding aite proteing from the $a_{1}, B$ and $y$ subunits of the $L$ type Ca-channel. Furthermore, Ambar et al. (1989), using competitive binding studiea in rat atria and brain, had inferred receptor subtypes for ET-1 and SRTX- $b$ but suggested that the two share a common binding site. Immunological evidence from antibodies agalnat ET-1 and SRTX-b reveal low cross-reactivity between the two peptides (Fleminger et al.1989). Fleminger et al. (1989) argued that this low reactivity reflects the fact that the antibodies recognize the variable sequence found within amino acids 47. This hypothesis was confirmed by CNBr cleavage of the methionyl reaidue at position 6 in SRTX-b and at position 7 in ET-1 (Fleminger et al., 1989). On the other hand, the binding properties, as well as the ability to induce phosphoinositide hydrolysis, were very similar in the modified and native peptides, indicating that, despite cleavage of the peptide bond, the biologically active conformation responsible for elther binding or phosphoinositide hydrolysis is retained. Probably this retention of activity reflects the importance of the two disulfide bonds. It thus appears that neither the argument for a role of the charge of $(-1)$ on the peptides loops of ET-1 and sRTX-b, nor aimilarities or dissimilarities in the c-terminal 'tall' of the two groups of peptides (ET/SRTX) can adequately explain their contractile or biochemical properties. Perhaps the only characteriotic -ilstinguishing the weak from strong contractile peptides is threonine at position 2. However, sves the presence of threonine at position 2 does not cc afer differing binding properties for the potent contractile SRIX-b versus 
the weakly contractile sRTX-c (Bdolah et al., 1989). In this context, the findings of Graur et al. (1988/89) must be emphasized as there is a strict conservation of the c-terminal amino acid sequence in the mamalian versus snake peptide except for SRTX-d which has Ile-Ile-Trp of the mamnalian group at position 19, 20 and 21 , respectively. Nonetheless, the pharmacological activities of SRTX-d and ET-1 differ. It Is also Interesting to note that the c-terminal hexapeptide, endothelin (16-21), difforentiates between endothelin receptors in the rat aorta and gulnea plg bronchus, where it Is neither an agoniat nor antagonist in the former but a full agoilet in tha latter (Magg1 et al., 1989). Cleavage of Trp21 from ET-1 and SRTX-b resulted in marked loss of vasoconstrictive ability (Kimura at al., 1988, Nakajima ot al., 1989). If vasoconstrictive ability is so dependent on Trp21, it follows that all eight peptides should be equieffective since all have Trp21; but this is not the case. The common factor of Trp21 and variable potencias of the eight peptides lend credence to suggeations of $\mathrm{Kloog}$ and sokolovaky (1989) that the variability of the c-terminal tall is of little functional olgnificance. The recent report by Galron ot al. (1990), that differont pathways are utilized by endothelin and sarafotoxin subsequent to phosphoinooltide hydrolyois in rat myocytes, lends credence to our hypothesis that the different seven amino acid sequence between ET-1 and sRTX-b may lead to different cell binding and/or utilization of messenger systems in different tissues. Indeed, such disgimilarities between ET-1 and sRTX-b have already been reported by Goetz ot al. (1989) for the effects of the two peptides on renal blood flow. This latter observation provides evidence for the report that there are two specifle recoptors in the rat kidney mesanglal cells (Suglura et a1., 1989). 
1.3.6 Mechanisms of action of the endothelins/sarafotoxins.

In the original paper of Yanagisawa et al. (1988a), it was suggested that endothelin may act directly on membrane ion channels. This hypothesis was oupported by the similarity between the structure of endothelin and those of the a-gcorpion toxins, which are known to bind to the tetrodotoxinsensitive Na-channelo. Based on the sensitivity of endothelin contraction to nicardipine, and the fact that $\mathrm{Na}$ - and $\mathrm{Ca}$-channels belong to the same family of voltage-dependent membrane ion channels as those oensitive to the ascorpion toxins (Tanabe et al., 1987), they proposed that endothelln could ropresent the endogenoua ligand for L-type calcium channels. Additional support for this hypothesis was obtained with the observation that, using patch clamp tochniques, ET-1 activated calcium influx currents through dihydropyridine voltage-sensitive Ca-channels (Goto et al., 1989). In addition, it has been reported that, in the rat aorta and portal vein, the contraction and ${ }^{45} \mathrm{Ca}$ uptake induced by endothelin, but not those caused by $a-$ acorpion toxin or veratridine, were insonsitive to tetrodotoxin, 0 -eonotoxin and Na removal, whereas nifedipine, nitrendipine, verapamil, nickel and Cafree medium inhibited these processes (Borges et al., 1989; Bglen et al., $1989)$.

There 1s, however, experimental evidence that contradicts this hypothesis. Indeed, Auguet et al. (1988) also observed that, in the rat aorta, the vasoconstrictor effects of endothelin and also the dihydropyridine Bay $K$ 8644, an agonist at the L-type Ca-channel, were different, and Bay $K$ 8644, but not endothelin, required a partlal pre-depolarization stimulation in order to evoke contractlone. Furthermore, the effects of endothelin were comparatively insensitive to nifediplne, nitrendipine, verapanil, diltiazem 
or gallopamil, whereas those of Bay X 8644 were markedly reduced (Auguet et a.., 1988; Criscione et al., 1989). In the rabbit aorta, the endothelin mediated contraction was insensitive to nlfediplne, nlcardipine and verapamil (Ohlstein et al., 1989), and in the mesenteric artery and jugular and mesenteric veing of this animal, nicardipine blocked Bay K 8644 avokad contractions but did not af fect those produced by endothelin (D.orleana-Juste et af., 1989). It has been reported that the hyperpolarization elicited by the $\mathrm{K}^{+}$-channel opener, cromakalin, reduced endothelin-mediated contractions in rat aortic stripa (Criscione ot al., 1989) Dichlorobenzamil, a blocker of $\mathrm{Na}^{+}-\mathrm{Ca}^{2+}$ exchange, also Inhibited endothelin-mediated contract lons; amiloride, had no effect (Criscione ot al ., 1989). The effects of dichlorobenzamil may, nowever, reflect the non-selective inhibition of endothelin-activated cation channels and not result from inhibition of the $\mathrm{Na}^{+}-\mathrm{Ca}^{2+}$ exchange syatem (Van Renterghem at al., 1989; criscione et al., 1989). The electrophyslological studies of Wallnoffer et al. (1989) and Van Renterghem (1989) have been most illuminating in elucidating the mechaniam of action of endothelin in comparison to other agonistg. Van Renterghen (1989) proposes that the electrophyslologic effect of ET-1 involves three types of channels. The first electrophysiological effect of ET-1 in spontaneously active cells is a translent hyperpolarization, during which the spontaneous electrical activity of the cell stops. It is followed by depolarization and a recovery of the electrical activity with a higher frequency. In cells with no spontaneous activity, ET-1 also produces a hyperpolarlzation followed by a depolarization during which a spiking activity ls triggered. In the presence of a 1,4dihydropyzidine (DHP), ET-1 still produces a depolarization following a transient hyperpolarization, but the spiking activity is abolished. The 
transient outward current induced by ET-1 was characterized as a $k^{+}$current. It is due to the opening of $\mathrm{Ba}^{2+}$ and charybdotoxin-sensitive $\mathrm{Ca}^{2+}$-activated $\mathrm{K}^{*}$ ehannols whlch are also involved in the spontaneous activity. The inward current activated by ET-1 reversed near $-1 \mathrm{mV}$ and 1 s due to the opening of $\mathrm{Ca}^{2+}$ permeable non-gelective cation channels. Van Renterghem et at. (1989) concluded that ET-1 changes the intracellular $\mathrm{Ca}^{2+}$ concentration by two different mechanisms: (i) it Liberates $\mathrm{Ca}^{2+}$ from internal stores (presumably through $I P_{3}$ production) and (ii) it activates a non-gelective cation channol In the plasma membrane that is permable to $\mathrm{Ca}^{2+}$. The depolarization induced by the opening of the non-selective catirs channels brings tho membrane potential level near the threshold for $\mathrm{L}-\mathrm{type} \mathrm{Ca}^{2+}$ channel activation and thereby eventualiy produces a spiking activity. consequentiy, substantial amounts of $\mathrm{Ca}^{2+}$ then flow into the cells via L-type ca-channels. The authors gurmiged that it is therefore not aurpriaing that blockers of L-type $\mathrm{Ca}^{2+}$ channels can eliminate a significant component of the ET-induced contractjon. The ramaining contraction component observed in the presence of channel blockers may be due to : (a) $\mathrm{Ca}^{2+}$ liberated from internal stores, (b) $\mathrm{Ca}^{2+}$ flowing through non-selective cation channels and (c) to a putative atimulation of proteln kinase $C$ by diacylglycerol. Wallnöfer et a1. (1989) have shown that in the mesenteric reoiseance vesgols (MRVs) of the rat, $\mathrm{ET}-1$ acts as a full contractile agonist, giving tonic contractions equivalent to those soen with NE and arginine vasopressin (AVP), but it produces only about 358 of the membrane depolarization $(-7 \mathrm{mV})$ produced by NE or AVP $(-20 \mathrm{mV})$. The reasons underlying this difference have been amply explained by van Renterghern et al. (1989). The authorg concluded that the degree of depolarization cauged by ET-1 would not alone induce enough $\mathrm{Ca}^{2+}$ entry through 
voltage-gengltive $\mathrm{Ca}^{2+}$ channels to yield tension $(12 \mathrm{mV}$ depolarization with $15 \mathrm{mM} \mathrm{K} \mathrm{K}^{+}$gave no tension). Hence, ET-1 must evoke other cellular effects in addition to membrane depolarization in order to activate the MRVs. Indeed, the sequential or temporal spacing of events, as proposed by Van Renterghem ot al, (1989), seem to provide the miseing link to the electrophysiologie study by Wallnöfer et al. (1989). However, Hay (1990), in examining the mechanism of ET-1-induced contractions of the rat aorta in comparison with the guinea pig trachea, concluded that ET-1-induced contractions of the rat aorta were more sensitive to the effects of incubation in a $\mathrm{Ca}^{2+}$-free medium, or with nicardipine or staurosporine, suggesting that differences exiat in the relative mechanisms whereby ET-1 produces contraction in different tiagues.

\subsubsection{Pharmacokinetics of endothelin.}

Pharmacokinetic studies with endothelin are few. Despite its long lasting vascular effects, the half-1lfe of this peptide in the plasma is very short; less than 2 minutes (Pernow et al., 1989). This has been attributed to a quick extraction of the peptide from playma during pulmonary circulation (de Nucci of al., 1988) or by renal, splenic and skeletal muscle clearance (Pernow et al., 1989). In rats, 1.v. Injected ${ }^{125}$ I-1 abeled ET-1 was rapidly eliminated from the blood stream, and the adminietered radioactivity distributed chlefly to the parenchyma of the lungs, kidney and liver (Shiba et al., 1989). This rapid decay rate was virtually unchanged oven when a pressor amount (1-2 nhol. $\left.\mathrm{Kg}^{-1}\right)$ of cold ET-1 is co-adminlatered with the radiolabeled tracer. Nevertheless, the pressor response usually lasts more than one hour. The extremely slow dissociation of ET-1 from 1ts receptors and/or other cellular components in vascular smooth muncle (Hirata ot al., 
1988b) may at least partly account fir the discrepancy betwesi the timecourse for elimination of the exogenously applied peptide from the circulating blood and that for the pressor effect of the peptide. Within a few minutes of 1.v. Injection of ${ }^{125} \mathrm{I}$-labeled ET-1, a major fraction of radioactivity was found in lungs, kidneys, liver and spleen (Kokesi et al., 1989 , Shiba et al, , 1989). Moreover, HPLC analyait of the injected ${ }^{125}$ Ilabeled ET-1 remaining in the circulating blood indicated that its chemical form wa not elgnificantly altered in the blood stream (Pernow et al., 1989; shlba et a1., 1989). 125 I-labeled ET-1 also appears to be very stable in heparinized whole blood in vitro at $37^{\circ} \mathrm{C}$. Thus, the rapid elimination of ETI from the circulation may be due to trapping of the intact peptide by the parenchymal organs. More recently, Sokolovsky et al.(1990) have shown that incubation of endotheline (ETs) with bovine kidnoy neutral endopeptidave (NEP) resulted in a selective two step degradation with loss of biochemical activity. The first step was the "nicking" of the Ser5-Leu6 bond, followed by cleavage at amino-terminal side of Ile19. The" nicked" peptide exhibited biochemical activities comparable to those of intact peptide - 1.e., binding to the ET-receptor, induction of inositol phospholipid hydrolysis and toxicity. The twice-cleaved product, however, was Inactive. On the other hand, the sarafotoxins (SRTKs) were more resistant to MEP than were the ETs: the $t_{1}$ for ET-1 was -1 hour whlle it was -4 hours for SRTX-b and evon higher for SRTX-C. The authors concluded that the results from these in vitro findings may indicate a regulatory role for NEP (or similar enzymes) in the phyaiological inactivation of ETs. This might also help to explain why, under physiological conditions, ETs may be less toxic than SRTXs. Neutral endopeptidase is said to be widely distributed in the body, occurring in 
opecific structures in the central nervous oystem, kidney, lung and intestines as well as In neutrophils and flbroblasts, but its concentration in vascular endothelial cells is very low. The trapping of radiolabeled ET-1 In certain organs, and the availability of neutral endopeptidage at a relatively high concentration may not just be a coincidence but a phyoiologie localization of substrate and enzyme for optimal degradation. Despite their elose biochemical and receptor binding properties, this may also be a noteworthy difference between SRTX-b and ET-1. It may well be that the structural differences could account for the differences in pharmacokineticn of the two peptides. Basal concentration of ET-1 in healthy human plasma geems to vary from one laboratory to another. Ando ot al. (1989) reported a value of $0.6 \pm 2 \mathrm{fmol} / \mathrm{mL}$ (meants.D.), Cernacek and stewart (1989) reported $0.26 \pm 0.24 \mathrm{pg} / \mathrm{mL}$ or $104 \pm 94 \mathrm{fmol} / \mathrm{L}$ and Suzuki et al. (1989) reported $1.5 \pm 0.5$ $\mathrm{pg} / \mathrm{mL}$ (range $0.7-2.4 \mathrm{pg} / \mathrm{ml}$ ) for females. In disease states such as cardiogenic shock, levels of $3.65 \pm 1.14 \mathrm{pg} / \mathrm{mL}$ have been measured (Cernacok and Stewart, 1989). Hopefully, more data on the pharmacokinetics of endothelin and sarafotoxin will become available and perhapo, with standardization of methods, the "norma1" plasma concentration of ET will be determined.

In summary, research with endothelin has left us with more questions tran answers. Notably, what are the physiologic roles of endothelln? Is endothelin the cauge or the effect of a pathologic state? Are the signal transduction pathways of ET-1 and SRTX-b the game? Finally, is endothelin a 'hormone' or autacold of gelf-destruction?

\subsection{Objectives.}

The preceding literature review indicates general agreement on the following areas: 
(i) Endothelin acts on a wide spectrum of target tissues and lacks species specificity. Furthermore, endothelin does not originate from endothelium alone.

(ii) Although ET-1 and SRTX-b show blochemical and binding characteristics, the existence of receptor subtypes allows for the possibility of these two peptides binding to distinct receptors and utilizing different signal transduction pathways.

The overall objectives of the thesis were : A) to compare the actions of endothelin-1 (ET-1) and arafotoxin S6b (SRTX-b) with those of a well characterized agonist, norepinephrine (NE) and B) identify and compare the transduction effector mechanisms utilized by these peptides with NE. Experiments were designed to answer the following questions:

1) Are the contractile mechanisms induced by these peptides and norepinephrine the aame in vascular and non-vascular amooth muscles?

2) Do ET-1 and SRIX-b Interact with the Bame receptor? 


\section{Chapter 2 \\ MATERIALS AND METHODS}

\subsection{Animals.}

Male Sprague-Dawley rats (225-250 g) were purchased from Canadlan Hybrid Farms, Halifax, Nova Scotia. These animals were used for all in yitro studies mentioned in the thesis.

The rats were houged in the animal care facility of the Faculty of Medicine, Memorial Unlveraity of Newfoundland, under minimal disease conditions, three rats to a cage. The rooms had a 12-hour 1ight, 12-hour dark, light oycle with controlled hunidity and temperature.

At all times, the animals had free access to food (Purina Rat chow from Charles River Inc., Montreal) and water.

2.2. Choice of tissue.

The preceding literature review llluetrates that a wide range of tisgues have been used in the study of endothelin and sarafotoxin. The major objective of this study was to determine whether endothelin and sarafotoxin shared the same membrane receptor-transduction system in smooth muscle. It was decided that a comparison of a vascular to a non-vascular preparation be made. The rat anococcygeus muscle and oesophageal tunica muscularis mucosa (TAM) were chosen as representatives of the non-vascular smooth muscle, and the portal vein and thoracic aorta for vaseular amooth muscle. The tiasue had to meet the following criteria, to be considered auitable:

(i) resilience of tissue in long experimental protocol;

(i1) repeated uge following recovery from exposure to given agonists; (iii) consistency of results; and 
(iv) sensitivity in terms of response at low concentrations.

2.3. Tissue preparation.

The rats were killed by a sharp blow to the head and exsanguinated by cervical transection. The thoracic aorta, portal vein, oesophagus and anococcygeut muscle were isolated and placed in warm $\left(37^{\circ} \mathrm{C}\right) \mathrm{Krebs}$ solution cont Inuously bubbled with oxygen/carbon dioxide $\left(958 \mathrm{O}_{2} / 58 \mathrm{CO}_{2}\right)$. Adherent connective tissue was carefully removed from the aorta, care being taken not to stretch the preparation. Any residual clot was removed from the lumen of the aorta with fine forceps before cutting the artery into $3-4 \mathrm{~mm}$ ring segments (Goldberg and Triggle, 1977). These rings were suspended between triangular shaped artorial hooks in a $10 \mathrm{ml}$ organ bath cortaining Krebe solution, at $\mathrm{pH} 7.4$, double jackered to maintain a temperature of $37^{\circ} \mathrm{C}$ and bubbled with $958 \mathrm{O}_{2} / 58 \mathrm{CO}_{2}$ continuously throughout the duration of experiments. One hook was anchored to a fixed point in the organ bath while the other was connected to the force-displacement transducer.

The portal vein was dissected free of adherent tissue, incised along its length to form a strip, and tied at both onds with ailk (Sutter and Ijung, 1977). The vain was then mounted in an organ bath for isometric force measurements in a similar manner as described above for the aorta.

The paired anococcygeus muscles were dissected free of connective tissue and each tied at its origin and insertion before removal from the animal for suspension in the organ bath with conditions ldentlcal as for the vascular preparations (modified from Gilleapie, 1972).

The tunica muscularis mucosa (TMM) of the oesophagus was set up as described by Bleger and Triggle (1985) and suspended in an organ bath with conditions identical to those described for the other tissues. 
All the tigsues were set up at a preload tension of $0.5 \mathrm{~g}$, except for the aortic ring preparation whose preload tension was get at $2 \mathrm{~g}$. The choice of pre-load tension was based on previously published evidence as to the optimal conditions for these tissues. The tlasues were allowed one hour to attain equilibrium under resting tension. Isometric tension was recorded on a Beckman R611 Dynograph using Grass FT 03C force displacement transducers. 2.4. Experimental protocol.

study 1: Tissue screening.

This study was performed using all four isolated preparations. During equilibration, Krebg buffer was changed every 15 minutes until the tialue maintained a stable baseline under the specified resting tension. Generally this took one hour to achieve. The tissues were alwaya prepared in palra except for portal vein which had to be isolated from two rats (attempts at using two halves from one rat had produced repeated experimental fallureb). Each tissue was exposed to $\mathrm{NE}$ and, using a concentration range of $10^{-9} \mathrm{M}$ to $10^{-4} \mathrm{M}$, a cumulative concentration-response curve was constructed. The tisaues were washed every 10 minutes until a return to baseline was achieved following which the tissues were allowed 30 minutes of recovery with change of Krebs buffer every 15 minutes. After recovery, each tissue was exposed to $\mathrm{ET}-1$ and, using a range of $10^{-12} \mathrm{M}$ to $10^{.7} \mathrm{M}$, a cumulative concentrationresponse curve was constructed. The tissues were washed every 10 minutes until a return to baseline was achieved. Since, with sRTX-b, recovery was rarely complete on a given day, the ame protocol was repeated on other experimental dates. From these experiments it was possible to determine the threshold concentration of response (sensitivity) of each tlosue and determine $\mathrm{BC}_{50}$ values for the different agonists as well as their recovery 
time in physiologlc buffer (Krebs). In the case of the oesophagus preparation, a muscarinic agoniat, cis-dioxolane (CD) was used to test the viablilty of the TMM before determining the effectiveness of NE as a epasmolytic agent.

Study 2: Role of extracellular calciue $\left(\mathrm{Ca}^{2+}\right)$.

Anococcygeus mugcle, which showed most resilience, was initially used for this study. All other conditions earlier atated in study 1 were applicable except the omission of $\mathrm{Ca}^{2+}$ from the krebs buffer. A pair of anococcygeus muscle was obtained from each rat and one of each pair was used as a control in which the Krebs buffer had $\mathrm{Ca}^{2+}$ at normal concentration. Three concentration response curves were constructed beyond the threshold value of $\mathrm{NE}$ for the tignues. Following recovery from NE, ET and SRTX-b concentration- response curves were constructed under identical experimental conditions.

Further examination of the role of extracellular $\mathrm{Ca}^{2+}$ involved the use of nifedipine (calcium channel antagonist). In these experiments, anococcygeus and aorta, having met the earller defined criteria, were used for the study. The protocol involved the initial challenge of a pair of tissues with NB, ET-1 and SRTX-b at concentrations equivalent to the $\mathrm{BC}_{30}$ values, which had been earlier determined, in normal Krebs buffer followed by repeated washing of tissues until a return to baseline was achieved. The tissues were allowed 30 minutes to recover with a change of $\mathrm{Ca}^{2+}-\mathrm{free}$ Krebs buffer every 15 minutes. Subsequently, ET-1 or SRTX-b $10^{-8} \mathrm{M}$ (10 nM) or $10^{-6}$ M NE was added to the organ wath and a $\mathrm{Ca}^{2+}$ concentration-response curve vas constructed. The tissues were again washed every 10 minutes with $\mathrm{Ca}^{2+}-\mathrm{free}$ Kreba buffer until a return to bageline was achieved and then they were 
allowed another 30 minutes to recover. The next gtage involved the addition of nifedipine (caleium channel blocker) at a concentration of $10 \mu \mathrm{M}$ to all the organ baths. These tissues were allowed one hour incubation in nifedipine before repeating $\mathrm{Ca}^{2+}$ concentration-reaponse curve in the presence of $1 \mu \mathrm{M} \mathrm{NE}, 10 \mathrm{nM} \mathrm{ET-1}$ and 1OnM SRTX, respectively. Since nifedipine was dissolved in absolute ethanol, control experiments to examine the effect of this solvent were performed.

Study 3: Role of extracellular and intracellular calcium $\left(\mathrm{Ca}^{2+}\right)$.

Anococcygeus muscles and rings from thoracle aorta were used in this protocol in pairs. All previous experimental procedures wore maintained except that $\mathrm{Ca}^{2+}$ was onltted from the Krebs buffer as was the case for examination of extraceliular calcium. $10 \mathrm{nM}$ ET or 10nM SRTX-b or $1 \mathrm{MM} N \mathrm{NE}$ were added to each organ bath and if any contractions occurred in the $\mathrm{Ca}^{2+}$ free medium, they were allowed to reach a stable platoau, following whlch a $\mathrm{Ca}^{2+}$ concentration response curve was constructed. Tissues were washed with $\mathrm{Ca}^{2+}$-free $\mathrm{Krebs}$ every 10 minutes until a return to bageline was achieved and allowed another $30 \mathrm{minutes}$ for recovery. Ryanodine, which interferes with the release of cellular $\mathrm{Ca}^{2+}$, was added to each organ bath to achieve a concentration of $10 \mu \mathrm{M}$ in $\mathrm{Ca}^{2+}$-free $\mathrm{Krebs}$ buffer. The tissueg were sllowed one hour incubation in ryanodine before repeating a $\mathrm{Ca}^{2+}$ concentration response curve in the presence of either ET-1, SRTX-b or NE. Subsequent1y, they were washed with $\mathrm{Ca}^{2+}$-free Krebs every 10 minutes until a return to baseline was achieved, following which ryanodine $10 \mu \mathrm{M}$ was added and the tissues allowed to Incubate for one hour. Finally, nifedipine $10 \mu \mathrm{M}$ was added and the tiasues allowed a further one hour incubation and a $\mathrm{Ca}^{2+}$ concentration responge curve constructed in the presence of ET-1, SRTX-b and 
NE.

In order to address the possibility that ryanodine is more effective in depleting intraceliular $\mathrm{Ca}^{2+}$ in the presence of an agoniat, further experiments using ryanodine alone, ryanodine with caffeine, and ryanodine concurrently with an agonlst in a $\mathrm{Ca}^{2+}$-free Krebs were degigned and run essentlally using the same experimental protocol.

Further experiments were conducted to examine the effect of other intracellular $\mathrm{Ca}^{2+}$ depletors, namely repeated agonist stimulation with $\mathrm{NE}$, or a combination of repeated agonist stimulation followed by ryanodine incubation, before construction of a $\mathrm{Ca}^{2+}$ concentration-response curve. To further evaluate the role of $\mathrm{Ca}^{2+}$ in the contractile process of ET-1, SRTX-b and NE, anococcygeus muscle responses to $10 \mathrm{nM} \mathrm{ET-1}$ and SRTX-b and $1 \mu \mathrm{M} \mathrm{NE}$ were measured in normal Krebs, Ca-free $\mathrm{Krebs}$, and following ryanodine treatment In normal krebs.

Additional evaluation of the role of $\mathrm{Ca}^{2+}$ in the contractile process Involved the use of the vocc opever Bay ka644. In these sets of experiments, a depolarizing (aubcontractile) - vel of $\mathrm{K}^{+}$(15 mM) in a Krebs buffer, was used. Isotonicity of Krebs buffer was achieved by substitution of $\mathrm{Na}^{+}$at equivalent concentration. Concentration-response curves to Bay X 8644 were constructed for anococcygeus muscle and aorta. The tissues were washed every 10 minutes until recovery was achieved and allowed a further 30 minutes for complete recovery. Subsequently, $1 \mathrm{nM}$ ET or SRTX-b or $100 \mathrm{nM} \mathrm{NE}$ were added to the reapective organ baths and concentration responge eurves to Bay $\mathrm{K} 8644$ repeated.

\section{Study Af Role of arachidonie acid metabolites.}

Paired anococcygeus muscles and rings of thoracic aorta were used for 
this study. They were isolatea and placed in $\mathrm{Ca}^{2+}-\mathrm{free} \mathrm{Krebs}$ buffer with experimental conditions identical to those previously applied. $\mathrm{Ca}^{2+}$ concentration-responge curves were constructed in the presence of $10 \mathrm{nM} \mathrm{ET-1}$ and SRTX-b and $1 \mu M$ NB, respectively. The tissues were washed with $\mathrm{Ca}^{2+}-\mathrm{froe}^{2}$ Krobs buffer evory 10 minutes until recovery to baseline was achieved following which a further 30-minute interval was allowed for complete recovery. $10 \mu \mathrm{M}$ indomethacin or $10 \mu \mathrm{M}$ MDGA was added to each organ bath and tisaues were incubated therein for one hour. $\mathrm{Ca}^{2+}$ concentration-responee curves in the presence of the three agonists were congtructed.

Further experiments were also designed in order to address the question of specifleity of NDGA. In these sets of experiments, anococcygeus and thoracic aortic rings were again used. A control experiment with $50 \mathrm{mM} \mathrm{K}^{+}$in $\mathrm{Ca}^{2+}$-free $\mathrm{Krebs}$ was designed and $\mathrm{Ca}^{2+}$ concentration-response curves constructed without and with NDGA. The three agoniats ET-1, SRTX-b and NE were examined in normal Krebs buffer by construction of agonist concentration-reaponse curves without and with NDGA. As with other experimento, and in order to ald agonist dissociation, the tissues were washed with $\mathrm{Ca}^{2+}$-free $\mathrm{Krebs}$ after the initlal concentration-response curver.

\section{study 5: Cross-desensitization.}

Paired anococcygeus muscles and thoracic aortic rings were used for this study. Each pair of tisgues was placed in a $10 \mathrm{ml}$ organ bath with normal Krebs solution and maintained under identical experimental conditions, as earlier defined. A palr of aortic rings and anococcygeus muscle were exponod to $\mathrm{NE}$ and another set to $\mathrm{KCl}$. After the Initlal concentration-reaponae curves to these two agonists, the tissues were washed every 10 minutes unt 11 recovery to baseline was achieved, then allowed another 30 minutes for full 
recovery. Threghold concentrations of ET-1 or SRTX-b (1 $\mathrm{nM}$ ) were added to one organ bath with one of a pair while its complementary unit served as a control. Tlsaues were allowed to incubate for 1 hour following the addition of either $\mathrm{ET}-1$ or SRTX-b and then concentration-response curves to NE and $\mathrm{KCl}$ were constructed.

2.5. Composition of buffers (Krebs bicarbonate buffer, adapted from Janis and Triggle, 1973) [aM] .

Norma 1 Krebs buffer (mM): NaCl $118 ; \mathrm{Kcl} 4.7 ; \mathrm{CaCl}_{2} 2.5 ; \mathrm{MgSO}_{4} 1.2 ; \mathrm{KH}_{2} \mathrm{PO}_{4}$ 1.2, $\mathrm{NaHCO}_{3} 12.5$; Dextrose 11.1 .

$\mathrm{Ca}^{2+}-$ free Krebs was made by omisaion of $\mathrm{CaCl}_{2}$ from the above with the addition of $0.01 \mathrm{mM} \mathrm{EGTA}$.

High $\mathrm{K}^{+}$Krebs (mM) NaCl $107.7, \mathrm{KCl} 15 ; \mathrm{CaCl}_{2}$ O; $\mathrm{MgSO}_{4} 1.2, \mathrm{KH}_{2} \mathrm{PO}_{4} 1.2$; $\mathrm{NaHCO}_{3} 12.5$; Dextroge 11.1 .

Very High $\mathrm{K}^{+} \mathrm{Krebs}$ (mM) $\mathrm{NaCl} 72.7 ; \mathrm{KCl} 50 ; \mathrm{CaCl}_{2} \mathrm{O} ; \mathrm{MgSO}_{4} 1.2 ; \mathrm{KH}_{2} \mathrm{PO}_{4} 1.2$; $\mathrm{NaHCO}_{3} 12.5$; Dextruse 11.1 .

Al1 constituento were reagent grede and were dissolved in deionized diatilled water.

2.6. Drugs and cheaicals.

The following agents were used: endothelin-1 and sarafotoxin (s6b) (Peptides International, Loulsville, KY).

NE, Indomethacin and NDGA were purchased from sigma chemical co., (St. Louls, MO).

Ryanodine and cls-dioxolane (Research Biochemicals Incorporated, Natick, MA).

Caffeine was obtained from J.T. Baker Co., Phlllipgburg, NJ. Nifedipine was a generoua gift from Bayer, Leverkusen, ผ. Germany. 
Ryanodine, nifedipine, indomethacin and NDGA were prepared as stock solutions of $10^{-2} \mathrm{M}$ in absolute ethanol; $10 \mu \mathrm{L}$ of stock solution added to 10 $\mathrm{ml}$ organ bath brought the bath concentration to $10^{-5} \mathrm{M}$.

All other reagents, of analar grade, were dissolved in distilled water and where appropriate, pH adjustmente for inereased solubility were made with $\mathrm{NaOH}$ or HCl.

2.7. Statistics.

The $E_{50}$ values were obtained by graphlcally calculating the concentration of agonist producing 508 of its maximum response (Fleming, Westfal1, DeLaLande and Jellet, 1972).

Where indicated, results are expressed as mean \pm SEM (standard error of the mean) calculated by the computer statistical programme of Gustafson, T.L. statistical gignificance was determined by student'g t tegt (one-tailed) for paired samples or analysis of variance (ANOVA) for independent samples using the above computer programe. Differences by the ' $t$ '-test or ANOVA ware conaidered to be aignificant if $p<0.05$. The srmple size (n value) id indicated in all tables. 


\section{CHAPTER 3}

\section{RESULTS}

\section{study 1: Tissue screening}

Due to the fallure of the TMM from the rat oesophagus to reapond to either ET-1 or SRTX-b (3 trials), the TMM was omitted from further studies. of the remaining three tigsues under consideration, the portal vein (Figure 4), showed great sensitivity in two parameters - frequency and amplitude of its spontaneous myogenic response - the responses were rather erratic (Figure 3). It also was omitted from further studies.

The anococcygeus and aortic preparations met the defined criteria and were subsequently used for all the in vitro work described in this thesis. In choosing anococcygeus muscle as the non-vascular smooth muscle of choice, the following useful properties, or characteristica, as enumerated by Goyal (1984) were considered viz :-

(1) It consiats entirely of gmooth muscle cells arranged in parallel bundles to form a sheet, so that there is a minlmal diffusion barrier for drug access or ion exchange studies.

(11) The muscle is represented bileterally so that control and test preparations can be taken from the tame animal.

Anatomically, this muscle is associated with the intestine but differs in a number of aspects from intestinal smooth muscle. Intestinal smooth muscle possessias apontaneous myogenic activity and is inhibited by stimulation of sympathetic nerves and exeited by the stimulation of parasympathetic nerven (Goyal, 1984). The anococcygeus muscle, by contrast, has a high stable reating membrane potentlal of $-60 \mathrm{mV}$, shows no spontaneous activity, either 
electrical or mechanical, and is excited by sympathetic nerves but inhibited by a non-cholinerglc, non-adrenergic pathway. The nature of this inhibitory transmitter is unknown (Creed and Gillesple 1973; Creed, Gillesple and Mulr, 1975).

Time-dependent responses were assessed by constructing four concentration-response curves to NE over a period of four hours. A logs of tone of about $15 \%$ of initial maximal response was noted (Table 1). In order to determine the optimal concentration range for these tissues and obtain EC 50 values, concentration-response curves to NR, ET-1 and SRTX-b were constructed. The results of these experiments are graphically presented (Flgure 5), which does not show the full concentration range of agoniata examined because the descenting limb of the hyperbola has been deleted for neatness. It was evident that concentrations of $\mathrm{NE}$ beyond $10^{-5} \mathrm{M}$ or $3 \times 10^{-8} \mathrm{M}$ for $\mathrm{ET}-1$ and SRTX-b were detrimental to $t$ issue responsiveness and rosulted in a loss of tension or subsequent non-response to these agonist. Furthermore $10^{-7} \mathrm{M}(0.1 \mu \mathrm{M})$ of ET-1 or SRTX-b induced myogenie-1ike activity in normally gilescent anococcygeus muscle which rendered the tiggues unusable for subsequent experiments in normal krebs buffer (Figure 6). As determined by the loss of myogenic activity, the tissues recovered more rapldiy from SRTX-b than $\mathrm{ET}-1$ with complete recovery apparent after $2.62 \pm 0.85$ and $5.22 \pm 0.06$ hourg respectively. Onitting $\mathrm{Ca}^{2+}$ from the Krebs solution gignificantly ("t"-test) reduced recovery times to $1.62 \pm 0.2$ and $2.40 \pm 0.51$ hours respectivaly (Table 2). Thus, a $\mathrm{Ca}^{2+}$-free Krebs buffer was used to wash tisgues whenever $\mathrm{gT}-1$, or SRTX-b, was used in an experimental protocol to hasten thase recovery from effects of the peptides. In order to avold the induction of myogenic activity by ET-1 or SRTX-b, concentrations of $30 \mathrm{nM}$, or greater, were rarely 


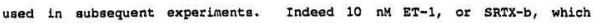
corresponda approximately to the $\mathrm{EC}_{50}$ valueg of these peptides was used, unless otherwlse stated. Nifedipine, at $10 \mu \mathrm{M}$, had no effect on the peptideinduced myogenic activity. Generally, contractile responses to ET-1 and SRTX-b seemed insenoitive to nifedipine in the nano-low micromolar range. study 2: Role of extracellular $\mathrm{Ca}^{2+}$

Control responses elicited by ET-1 and SRTX-b (10 nM) or NE (1 $\mu \mathrm{M})$ were approximately equieffective in terms of tension developed (Figure 7). In $\mathrm{Ca}^{2+}-\mathrm{free} \mathrm{Krebs}$, the three agonists generated approximately similar levels of tone in the aorta and anococcygeus musele, corresponding to 188 and 58 of maximum regponse in the controls respectively (Table 3). Muscle tone generated by the peptides even in the absence of external $\mathrm{ca}^{2+}$, was maintained in contrast to that with NE (Figure 8). Nifedipine was used in the experiments designed to determine the role of vocCs in regulating the ent: $Y$ of extracellular $\mathrm{Ca}^{2+}$, Nifediplne $(10 \mu \mathrm{M})$ did significantly reduce by " $\mathrm{t}$ "toet only (not by ANOVA) the responses to ET-1, but not to SRTX-b and $N E$ in the aorta (Table 4 ; see also Figure $9 a, b$ and $c$ ). In the anococeygeus, $10 \mu M$ nifedipine signiflcantly reduced the mexinal response to ET-1 (Fig. 10a), but responses to SRTX-b (Fig. 10b) and NE (Fig. 10c) were not significantly reduced. However, it is noteworthy that the decrease in sensitivity for ET1, SRTX-b and ME was m-e than that observed in the aorta. The persistence of nifedipine in the tissues was assessed by repeating $\mathrm{Ca}^{2+}$ concentrationresponse curves in the presence of a stated agoniat concentration after washing every 10 minutes for one hour following the return to baseline. In the aorta, recovery from nifedipine in the presence of ET-1 and SRIX-b did not occur. The response of the aorta to NE did not show recovery after 
nifedipine application, aithough the maximum contractile response, post nifedipine washout, approached the control maximum, but, as with the two peptides there was a decrease in sensitivity as evident by the ohift of the curve to the right (Figure $11 \mathrm{a}, \mathrm{b}$ and $c$ ). In the anococcygeus, recovery from nlfedipine in the presence of the three agoniste exhibited a similar pattern (see Figure 12a, $b$ and $c$ ). As a result of the incomplete rocovery from nifedipine, tissues which had been axposed to nifedipine were not used for further investigations.

As Eummarized in Table 3 , it is evident that simple exposure to a $\mathrm{Ca}^{2+}-$ free medium drastically reduced contractile responses to ET-1, SRTX and NE In both the aorta and the anococcygeus. To further evaluate the role of $\mathrm{Ca}^{2+}$ in the contractile processes of ET-1, SRTX-b and NE, the responses to $10 \mathrm{nM} E T-1$ and SRrX-b and $1 \mu \mathrm{M}$ NE were measured in normal $\mathrm{Krebs} \mathrm{Ca}^{2+}-\mathrm{fres} \mathrm{Krebs}$, and after treatment with ryanodine for 1 hour followed by re-introduction of normal Krebs (Figure 13). Anococcygeus tissues, which had been previously exposed to normal Krebs but were switched to a $\mathrm{Ca}^{2+}-\mathrm{free}$ Krebs Immedlately before agonist exposure, demonstrated aignifieantly reduced responses to all three agoniats with the inhibition of regponses to ET-1 and SRTX-b being greater than that observed for $\mathrm{NE}$. Ineubation for one hour in a $\mathrm{Ca}^{2+}-\mathrm{free}$ Krebs plus $10 \mu \mathrm{M}$ ryanodine, followed by re-introduction of normal Krabs and agonist, led to an enhancement of the responses to ET-1 and SRTX-b. The effect on the SRTX-b response was significantly greater than that for ET-1. The response to NE was not different from the control. Figure 14 illustrates the effect of the above protocol in the aorta. In the aorta, the control responses of the peptides in normal Krebs did not differ signiflcantly from each other but each was signiflcantly different from the $\mathrm{NE}$ responge. In 
$\mathrm{Ca}^{2+}$-free Krebr, the responses to ET-1 and NE were not significantly different from their control responses in normal Krebs, whereas sRTX-b in $\mathrm{Ca}^{2+}$-free Krebs demongtrated a eigniflcantly reduced responge compared to its control. Like anococcygeus, the response of the aorta to NE in a $\mathrm{Ca}^{2+}-\mathbf{f r e e} \mathrm{Krebs}$ was Blgnificantly higher than the responses to either ET-1 or SRTX-b. In contrast to studies with the anococcygeus, the post ryanodine responses to ET-1, SRTX-b and NE in the aorta did not differ significantly from their controls.

Study 3: Role of extracellular versus intracellular $\mathrm{Ca}^{2+}$

Experiments were conducted to further compare and evaluate the role of extracellular versus intracellular $\mathrm{Ca}^{2+}$ in the contractile response to $\mathrm{ET}-1$, SRTX-b and NE. After obtaining the control concentration-response curves to $\mathrm{Ca}^{2+}$ in the presence of the appropriate agonist, tigsues were washed and incubated in $10 \mu \mathrm{M}$ ryanodine for one hour following which the $\mathrm{Ca}^{2+}$ concentration-response curves were repeated. Responses to ET-1 in the anococcygrus were aignificantly enhanced by ryanodine treatment alone (Figure $15 a, b$ and $c)$. Subsequently, the tissues were again subjected to ryanodine treatment in the presence of $10 \mu \mathrm{M}$ nifedipine in 1 ight proof chambers and $\mathrm{Ca}^{2+}$ concentration-responge curves were again repeated in the presence of appropriate agonist. Responses to ET-1 and NE wero signifieantly reduced in the anococcygeus but less go for SRTX-b which was not significantly reduced (Figure $15 \mathrm{a}, \mathrm{b}$ and $\mathrm{c}$ ). In the aorta, with a combination of ryanodine and nifedipine treatment, there was marked and significant inhibition of the contractile response to $\mathrm{ET}-1$ and $\mathrm{NE}$ but not to SRTX-b (Figure $16 \mathrm{a}, \mathrm{b}$ and $c$; see also Table 4). The digcrepancy arising from visual assegsment of concentration response curves (Flgures 15 and $16\{a, b$ and $c\}$ ) against Table 
4 ig the result of presentation of data derived from inhibition of control maximal response subjected to statistical analysig. Further explosation of the pools of intracellular $\mathrm{Ca}^{2+}$-utilized by the agonist was necessitated, ance ryanodine alone did not entirely deplete the cell of the intracellular $\mathrm{Ca}^{2+}$ utilized for contraction. Thus, responses to $\mathrm{NE}$ even after incubation of both aorta and anococcygeus with ryanodine were maintained. Patel and Triggle (1986) had denonstrated intracellular $\mathrm{Ca}^{2 *}$ depletion by repeated otimulation of the rat tall artery in $\mathrm{Ca}^{2+}-\mathrm{free}$ Krebs with NE. Repeated stimulation with NE can partially deplete the intracellular stores of $\mathrm{Ca}^{2+}$ from both the anococcygeus and aorta, however, there is a $\mathrm{Ca}^{2+}$-pool which resists depletion even after an extended, and repeated, stimulation with NE for 2-3 hours (Figure $17 \mathrm{a}$ and $b$ ). Figures 18 and 19 (a, $b$ and $c$ ) demonstrate the response characteristics for NE depletion which, when compared to ryanodine depletion (Figures 15 and 16 ( $a, b$ and $c)$, were similar, except that syanodine was more effective in reducing responses to SRTX-b when used with nifedipine. Further attempts to addregs the question of which intracellular $\mathrm{Ca}^{2+}$ pools are sensitive to ryanodine and/ or $\mathrm{KE}$, involved experiments in which tisouea had been repeatedl $Y$ otimulated with NE and then incubated in ryanodine for one hour. The results from studies with the anococcygeus (Figure 20a, b and c) maintained a pattern similar to thost for ryanodine alone (Figure $:\{a, b$ and $c$ ). The results from studies with the aorta, Figure 21a, $b$ and $c$, were bdentical to those obtained following $\mathrm{Ca}^{2 *}$ depletion with NE alone(Figure $19 a, b$ and $c$ ). It has been suggested that the effectiveness of ryanodine in depleting earcoplaamic reticulum $\mathrm{Ca}^{2 *}$ id enhasced by the simultaneous presence of an agonist. In the anococcygeus, the maximal contractile responses to SRTX-b after ryanodine treatment alone or 
ryanodine plus caffeine or concurrent application of ryanodine plua sRTX-b were apparently enhanced when compared to the control responses (Figure 22a, b and c). Howevor, evaluation of the three treatments by Axova showed that these differences were not significantly differest from each other. Pigure $23 a, b$ and $c$ illugtrates the response obtalned from anococcygeus with $10 \mathrm{nH}$ ET-1. Evaluation of the three treatments by ANOVA showed these differences were not significant. In the aorta, treatment with ryanodine, or ryanodine plus caffeine, again, resulted in no significant differences from the respective controle (Figure 24a, b and c). Similarly in the aorta, with ET-1 as the agoniat, the differences were not significant when examined by ANOVA as three independent variables (Figure $25 a, b$ and $c$ ).

since nlfedipine was only partially effective at inhibiting $\mathrm{Ca}^{2+}$ entry, the further elucidation of router of entry of extracellular $\mathrm{Ca}^{2+}$ were necesgary. For this purpose, a known L-type calclum channel opener Bay $\times 8644$ was used with a partially depolariziny (15 $\mathrm{mM} \mathrm{k}^{+}$) Krebs buffer to explore the effects of ET-1, SRTX-b and NE. Figure 26a, b and $c$ shows the response in anococcygeus to Bay K 3644 without, and with, sub-threshold concentrations of $1 \mathrm{nM}$ ET-1 and SRTX-b and $100 \mathrm{nM}$ NE. An apparent enhanced contract1le response to the three agonists was noted but these differences were not statistically evaluated for significance primarily because the responses in the anococcygeus in the presence of Bay K 8644 (see Figure 27) were not concentration-dependent. Figure $28 \mathrm{a}, \mathrm{b}$ and $\mathrm{c}$ demongtrates the enhancenent of Bay $K 8644$ responges in the aorta in the presence of the three agonists under examination.

Study 4: Role of arachidonic acid metabolites

The role of the production of arachidonic acld metabolites in response 
to $\mathrm{ET}-1$, SRTX-b and $\mathrm{NE}$ was explored by comparing control $\mathrm{Ca}^{20}$ concentration response curves in the presence of $10 \mathrm{nM} \mathrm{ET-1,} 10 \mathrm{nM}$ SRTX-b or $1 \mu \mathrm{M} \mathrm{NE}$ in the absence of or following a one hour incubation with the cyclooxygenace inhibitor, indomethacin(10 $\mu \mathrm{M})$. Figure 29 and 30 show no enhancenent of the responses to the three agonists. There were no significant differences from controls (Table 4).

A further elucidation of the role of agonist-induced arachidonic acid metabolite production Involved the use of the lipoxygenase inhibitor, NDGA. In the anococcygeus preparation (Figure $31 \mathrm{a}, \mathrm{b}$ and $\mathrm{c}$ ), the responses to ET-1 and NE, but not SRTX-b, were significantly reduced by $10 \mu \mathrm{M}$ NDGA $($ Pohl ot al., 1987). In the aorta (Figure $32 a, b$ and $c$ ), the responses to sRTX-b and NE were not Bignificantly reduced by NDGA, whereas NDGA signiflcantly reduced the responses to $\mathrm{BT}-1$.

The isgue of epecificity of inhibition produced by NDGA was addresaed by designing experiments which compared the Inhibition by NDGA of the concentration-dependent contractile responses to $\mathrm{Ca}^{2 *}$ in the presence of $\mathrm{ET}-1$, SRTX-b or NB versus $50 \mathrm{mM} \mathrm{K}^{+}$. Figures $33 \mathrm{a}$ and $\mathrm{b}$ demonatrate that, in the anococeygeus preparation, a dignificant inhibition of the NE was achioved (Table4). A Bimilar, but insignificant pattern of inhibition by NDGA of $K^{*}$ Induced contractions was noted (Figure $33 \mathrm{a}$ and b). Figures $34 a$ and b demonstrate that the reduction of the contractile response by NDGA was not noted in the aorta with ejther NE or $\mathrm{K}^{+}$induced contractions.

study 5: crose-desensitization to agonist

Experiments were designed in order to evaluate whether desensitization of the anococcygeus and the aorta occurred following exposure to subthreshold concentration of either SRTX-b or ET-1. Figures 35a and b illustrate the 
effects of the prior axposure of the anococeygeus to a sub-contractile concentration, $1 \mathrm{nM}$ of SRTX-b, and $1 \mathrm{nM}$ of ET-1, respectively, on concentration-response curves to NE. Prior exposure to SRTX-b (Figure 35a), but not ET-1 (Figure 35b), significantly ("t"-test), reduced subsequent reaponge日 to NE. Figures $35 \mathrm{c}$ and $d$ illuatrate the effects of tile same procedure on the concentration-response curves to $\mathrm{KCL}$ and indicate that the presence of ET-1 but not SRYX-b, significantly onhanced the reaponses to KCL. In the aorta (Figures $36 \mathrm{a}$ - d) neither the prior exposure to $1 \mathrm{nM}$ sRTX-b nor 1 nM ET-1 resulted in a aignificant ("t"-tost) deconaitization of the responses of the tissues to subsequent concentration-response curves to either NE or KCL. However, significant ("t"-test) enhancement was noted for KCL concentration-response curves following exposure to $1 \mathrm{nM}$ SRTX-b or $1 \mathrm{nM}$ BT-1 (Figures $36 \mathrm{c}$ and d), and also for NE concentration-response curves following exposure to $1 \mathrm{nM}$ SRTX-b (Figure 36a), but not to $1 \mathrm{nM}$ ET-1 (Figure 36b) . 
Figure 2: Anlno acld sequences of endothelins and sarafotoxine.

(See liat of abbreviations for alternative single letter abbreviations for amino acids.) 
Cys-Ser-Cys-Ser-Ser-Leu-Met-Asp-Lys-Glu-Cys-Val-Tyr-Phe-Cys-His-Leu-Asp-Ile-Ile-Trp ET-1 C ss-Ser-Cys-Ser-Ser-Trp-Leu-Asp-Lys-Glu-Cys-Val-Tyr-Phe-Cys-Ilis-Leu-Asp-Ile-Ile-Trp ET-2 Cys-Thr-Cys-Phe-Thr-Tyr-Lys-Asp-Lys-Glu-Cys-Val-Tyr-Tyr-Cys-His-Leu-Asp-Ile-Ile-Trp EX-3 Cys-Ser-Cys-Asn-Ser-Trp-Leu-Asp-Lys-Glu-Cys-Val-Tyr-Phe-Cys-His-Leu-Asp-Ile-Ile-Trp ET-4 Cys-Ser-Cys-Lys-Asp-Met-Thr-Asp-Lys-Glu-Cys-Leu-Asn-Phe-Cys-IIis-Gln-Asp-Val-Ile-Trp SRTX-a

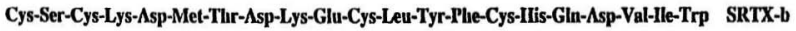
Cys-Thr-Cys-Asn-Asp-Met-Thr-Asp-Glu-Glu-Cys-Leu-Asn-Phe-Cys-His-Gin-Asp-Val-Ile-Trp SRTX-c Cys-Ihr-Cys-Lys-Asp-Met-Thr-Asp-Lys-Glu-Cys-Leu-Tyr-Phe-Cys-Illis-Gln-Asp-Ile-Ile-Trp SRTX-d I 5 10 15 20

Figure 2 Amino acid sequence of endothelins and sarafotoxins 
Figure 3: Illuetration of the erratic response of the rat portal vain to ET-1, SRTX-b and NE $(n=6)$. 


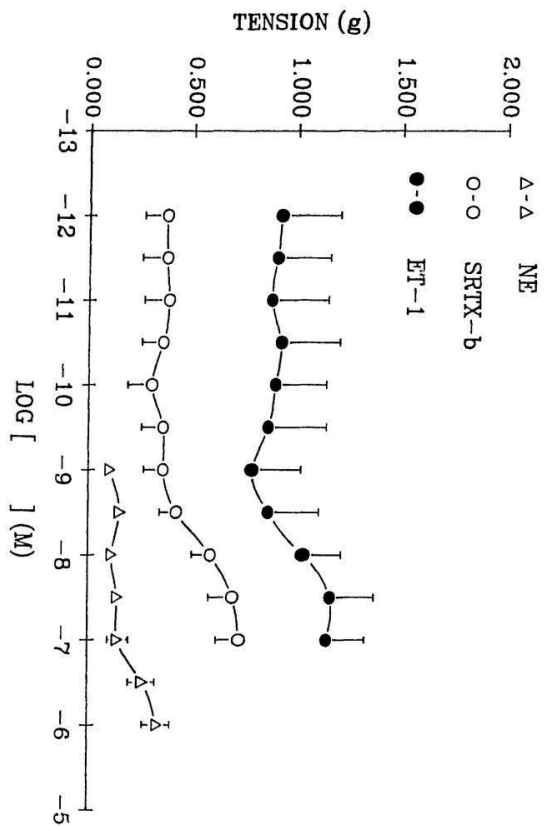


Figure 4: Illustrates the response of rat portal vein to sRTX-b with changes in frequency and amplitude of response at agonlst concentrations as low as $10^{-10} \mathrm{M}$. 
TISSUE TENSION (g)

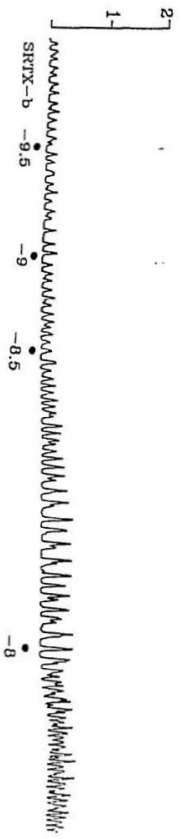


Figuxe 5: Concentration-reaponge curves for ET-1, SRTX-b and NE with the anococeygeus muscle in normal krabs buffer. Points are the mean (= S.E.M.) of $n=6$. $\quad \mathrm{SC}_{50}$ values were obtalned from these curvea. 


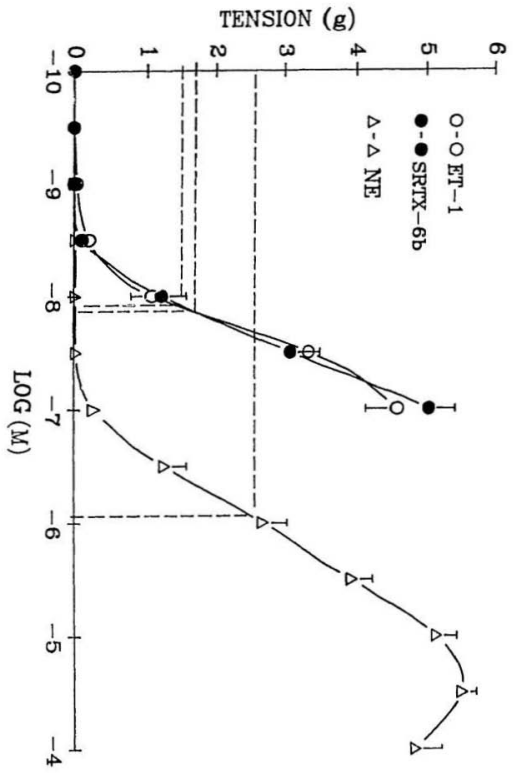


Pigure 6: Induction of myogenic actirity in the anococeygaus muacla following washout of A) $0.1 \mu \mathrm{M} \mathrm{ET-1;} \mathrm{8)} 0.1 \mu \mathrm{M} \mathrm{SRTX-b}$ with normal Krebs buffer. 
64

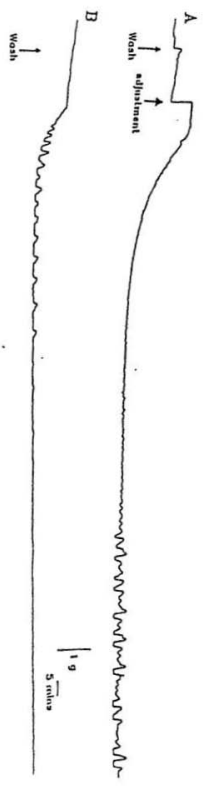

1 
rable 1:

Time-dependent variation in the response of the anococcygeus muscle to four concentration-reaponse curves obtained to NE over a four hour period.

\begin{tabular}{lllll} 
& & 2 & 3 & 4 \\
\cline { 2 - 5 } $\log$ conc. $(M)$ & 1 & 2 & .06 & .08 \\
-7.5 & .06 & .06 & .08 & .40 \\
-7.0 & .41 & .30 & .31 & .98 \\
-6.5 & 1.21 & .81 & .91 & 2.13 \\
-6.0 & 2.63 & 2.03 & 2.08 & 3.5 \\
-5.5 & 4.70 & 3.83 & 3.65 & 5.65 \\
-5.0 & 7.23 & 6.7 & 5.6 & 6.88 \\
-4.5 & 8.12 & 8.0 & 6.8 & \\
\hline
\end{tabular}

Tissue tension is measured in grams. 
Table 2 !

Effect of $\mathrm{Ca}^{2+}$-omigsion on recovery time (hours) of the anococcygeus muscle from peptide-induced myogenie activity.

Normal Krebs $\left(2.5 \mathrm{mM} \mathrm{Ca}{ }^{2+}\right) \quad \mathrm{Ca}^{2+}-$ free $\mathrm{Krebs}$

ET-1 (n= 4$)$

$5.20 \pm 0.66$

$2.40 \pm 0.50$

SRTX-b $(n<4)$

$2.62 \pm 0.55$

$1.62 \pm 0.20$

Time values are Means $( \pm$ S.E.M.)

- Denote significant differences (ANOVA) between ET-1 and SRTX-b. $0<0.5$. 
Figure 7: Illustrates the response to equief fective concentrations of ET1, SRIX-b and $\mathrm{NR}$ at their approximate $\mathrm{EC}_{30^{8}}$ in : (a) anococcygeus and (b) aorta. Chart apeed throughout this study was maintained at $0.25 \mathrm{~mm} / \mathrm{sec}$. 

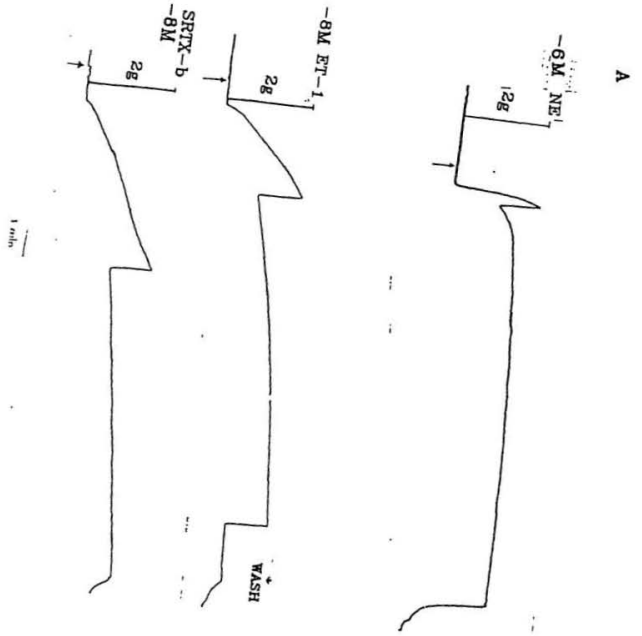


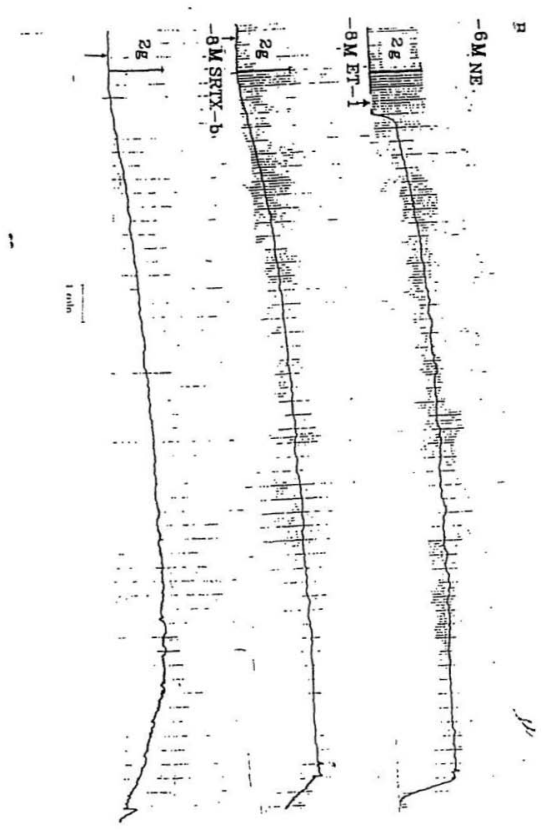

69 
Table 3: Effect of removal of extracellular $\mathrm{Ca}^{2+}$ on contractile responses of anococcygeus and aorta to ET-1, SRTX-b and NE.

\begin{tabular}{llll}
\hline & & Anococcygeus & Aorta \\
\hline $\mathrm{ET}-1$ & $(10 \mathrm{nM})$ & $5.16 \pm 0.81$ & $17.0 \pm 3.0$ \\
SRTX-b $(10 \mathrm{nM})$ & $4.98 \pm 0.70$ & $15.3 \pm 1.6$ \\
$\mathrm{NE}$ & $(1 \mu \mathrm{M})$ & $5.92 \pm 1.50$ & $21.0 \pm 2.3$ \\
\hline
\end{tabular}

Values are means of percentage maximum control responses ( e.g. in the presonce of extracellular $\mathrm{Ca}^{2+}$ ) \pm S.E.M. $(\mathrm{n}=4)$ 


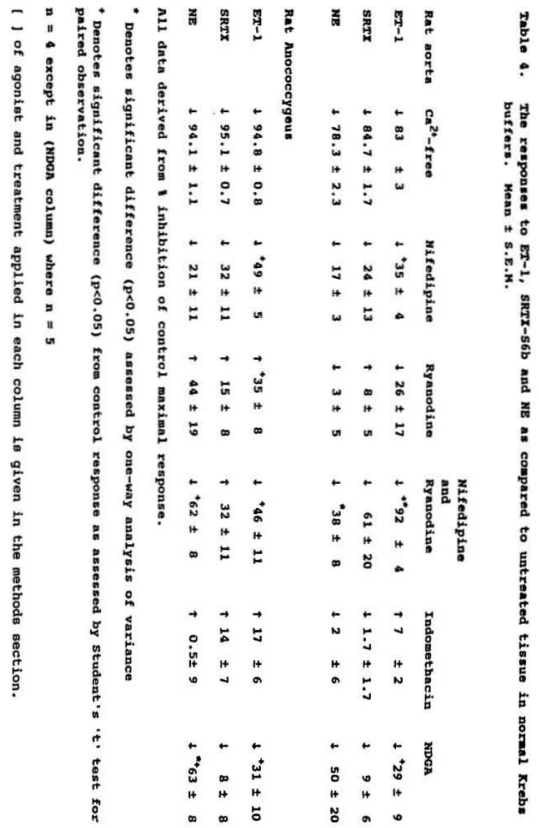


Figure 8: Illustration of the maintained tone induced by ET-1 and SRTX-b compared to the non-sustal.ad tone induced by $\mathrm{NE}$ in $\mathrm{Ca}^{2+}-\mathrm{free}$ Krebs buffer.
A) Anococcygeus
B) Aorta 


\section{TENSION(g)}

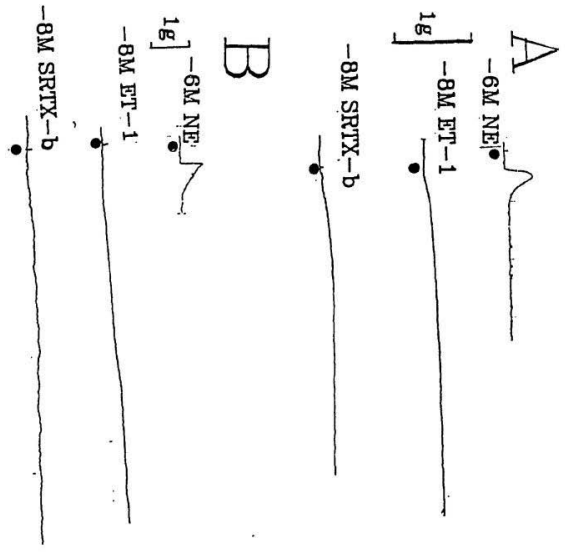


Figure $9 a, b$ and $c$ Effect of $10 \mu \mathrm{M}$ nifedipine on $\mathrm{Ca}^{2+}$ concentrationresponse obtained in the aorta in the presence of: a) $10 \mathrm{nM} \mathrm{ET-1;}$ b) $10 \mathrm{nM}$ SRIX-b; and c) $1 \mu \mathrm{M} \mathrm{NE}$. Open and closed symbols represent control and nifedipine treatment, respectively \pm s.E.K. $(n=4)$ 


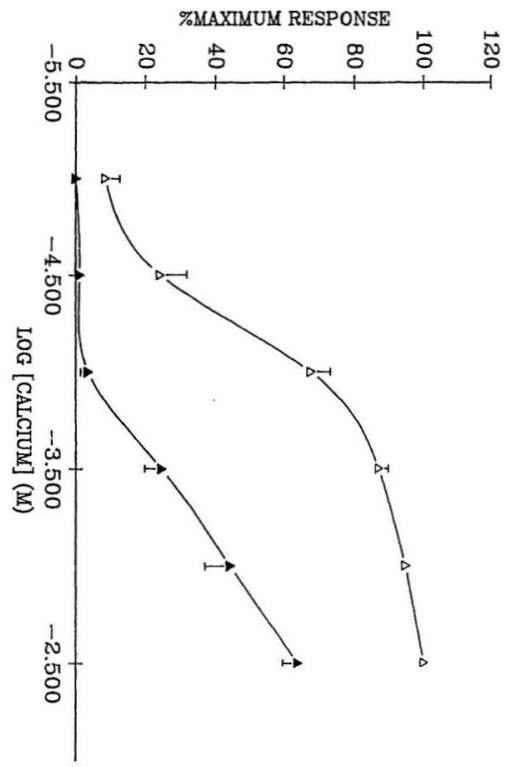




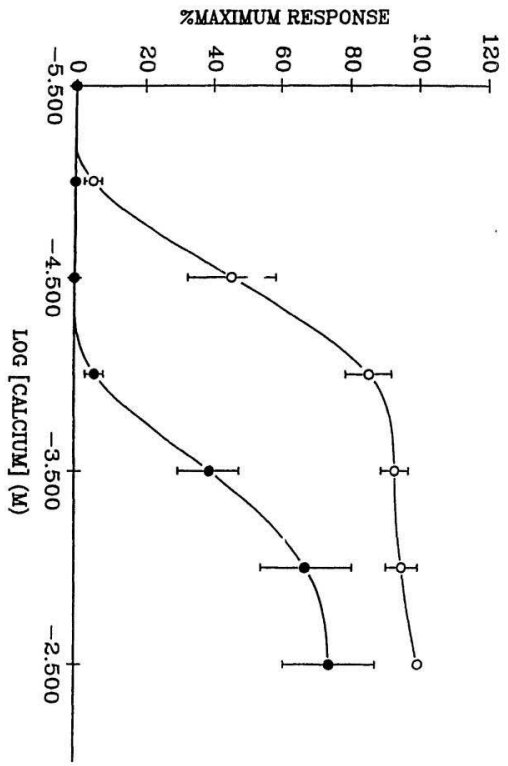

$\tilde{\sigma}$ 


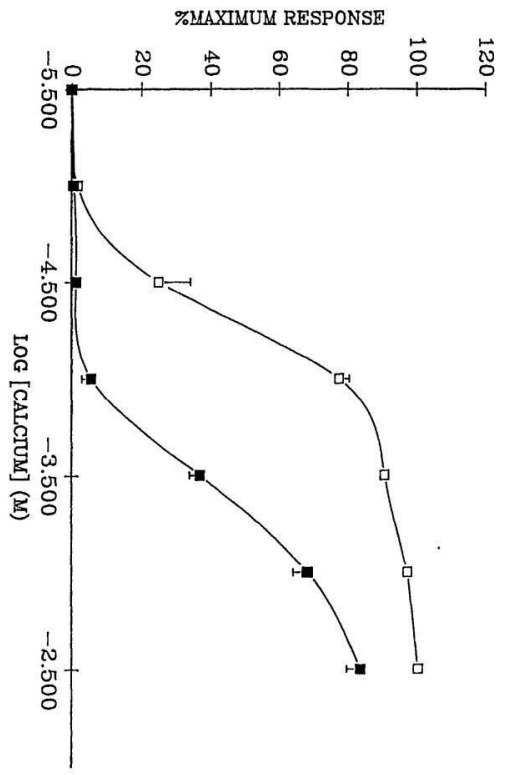

ล 
Figure 10a, b and c:

Effect of $10 \mu \mathrm{M}$ nifedipine on $\mathrm{Ca}^{2+}$ concentrationresponse obtained in the anococcygeus in the presunce of: a) $10 \mathrm{nM} \mathrm{ET-1;} \mathrm{b)} 10 \mathrm{nM}$ SRTX-b; c) 1 $\mu \mathrm{M} \mathrm{NE}$. Open and closed symbols represent control and nifedipine treatment, respectively \pm S.E.M.. $\quad(n=4)$ 


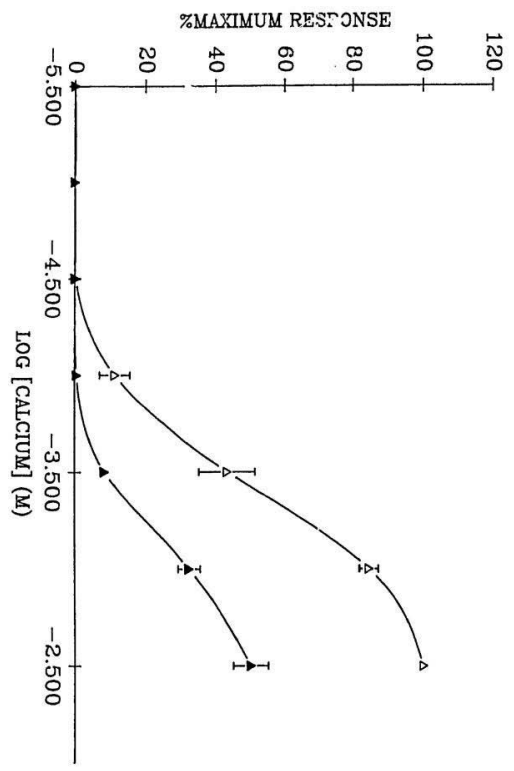

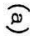




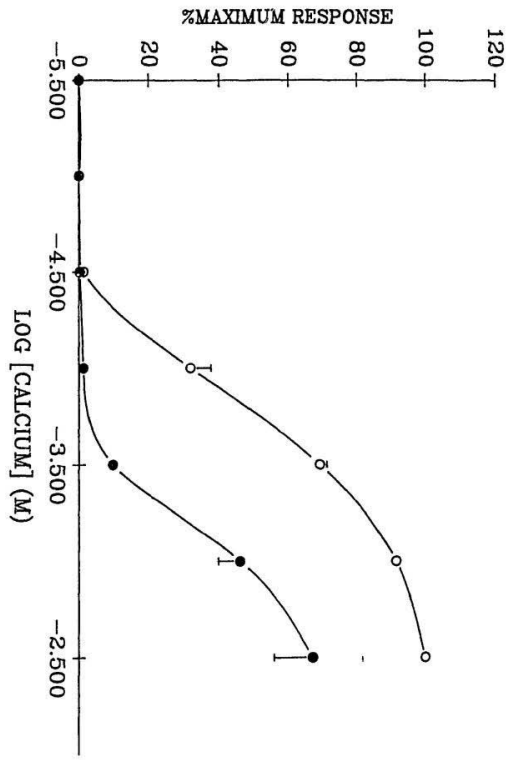

$\widehat{\sigma}$ 


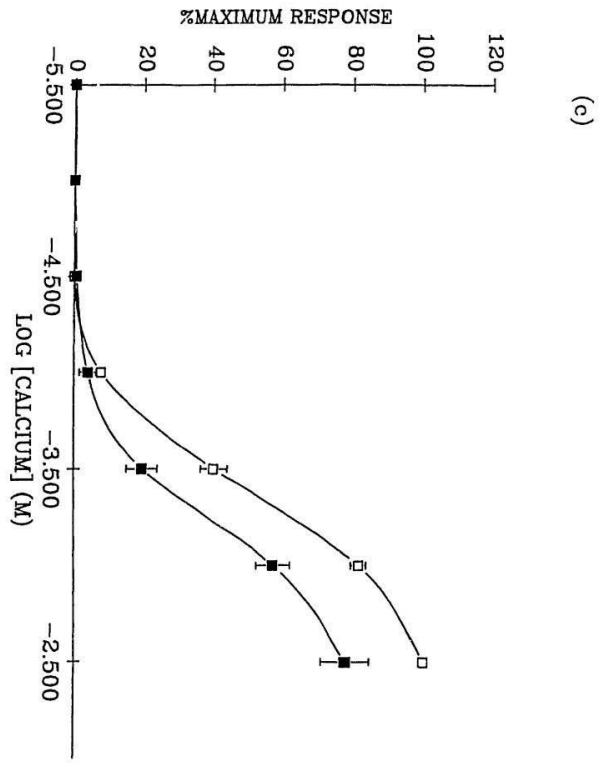


Figuze 11a, b and $c$ :

Ilustration of the persistent effect of $10 \mathrm{\mu M}$ nifediplne on $\mathrm{Ca}^{2+}$ concentration-response obtalned in the aorta in the presence of a) $10 \mathrm{nM} \mathrm{ET-1;} \mathrm{b)} 10 \mathrm{nM}$ SRTX-b; c) $1 \mu M$ NE. Control curved \pm s.E.M. are represented by open symbols, e.g. O-O, and in the presence of nifedipine by filled symbols, e.g. and post-nifedipine by $\Delta-\Delta . \quad(n=4)$ 


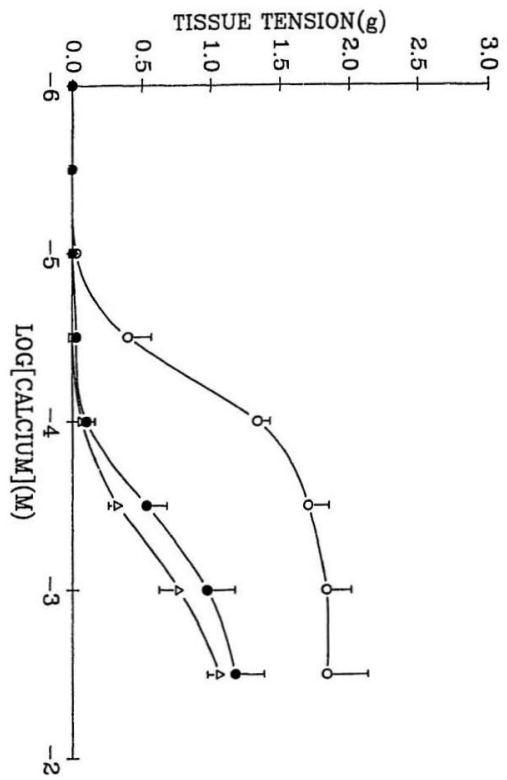




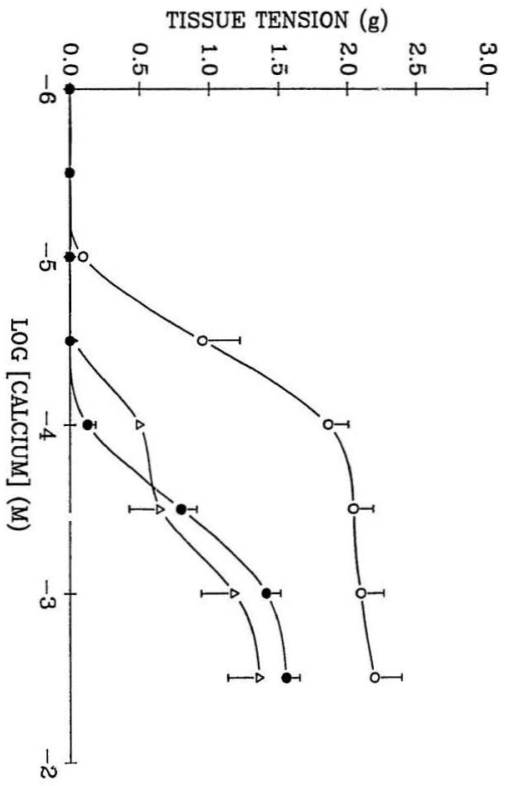

$\widehat{\sigma}$ 


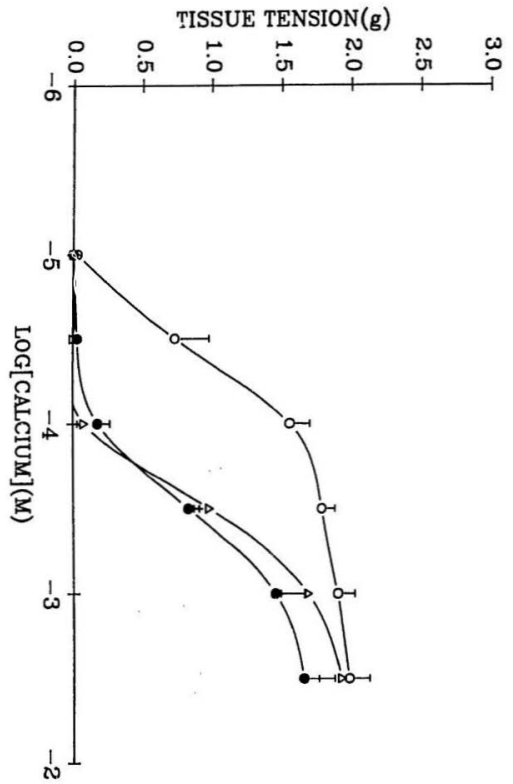

$\widehat{อ}$ 
Illustration of the persiatent inhibition following $10 \mu M$ nifedipine application on the $\mathrm{Ca}^{2+}$ concentration-response curve obtained in the anococcygeus in the presence of a) $10 \mathrm{nM} \mathrm{ET-1;} \mathrm{b)}$ $10 \mathrm{nM}$ SRTX-b; c) $1 \mu \mathrm{M}$ NE. Control curves \pm S.E.M. are represented by open symbols, e.g. $0-0$, and in the presence of nifedipine by filled symbols, e.g. - and post-nifedipine by $\Delta-\Delta . \quad(n=4)$ 


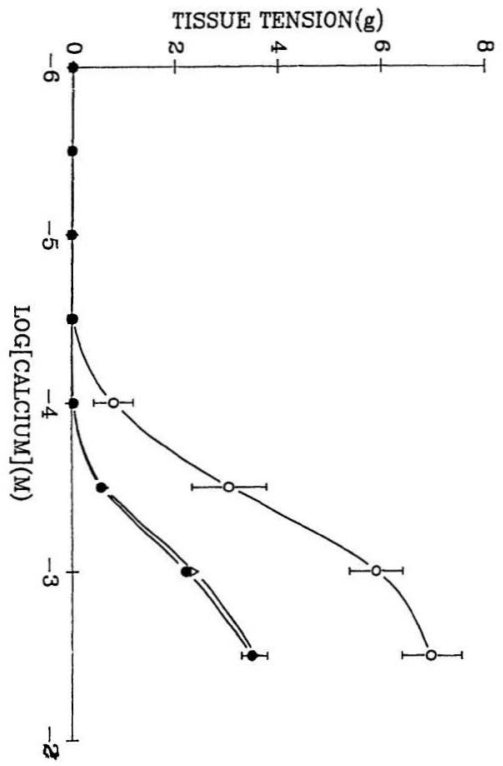

증 


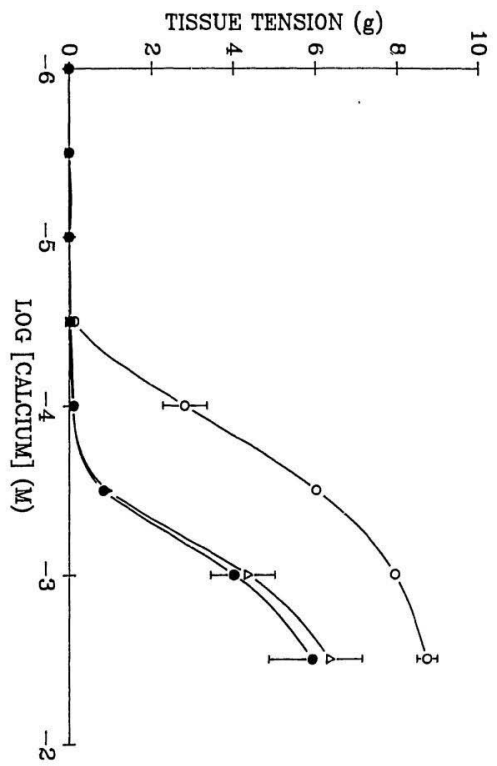

$\bar{\sigma}$ 


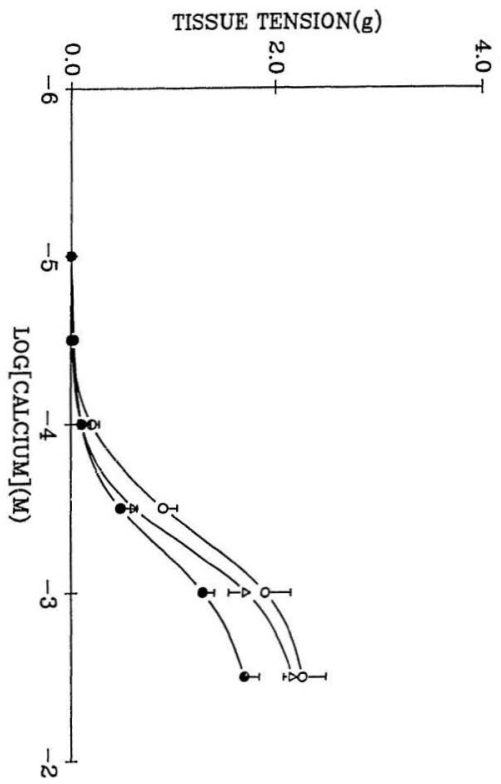

อ 
Figure 13: A comparison of the contractile effects induced by $10 \mathrm{nM}$ ET-1, SRTX-b and $1 \mu \mathrm{M} \mathrm{NE}$ in the rat anococcygeus preparacion in normal Krebs and $\mathrm{Ca}^{2+}-\mathrm{free} \mathrm{Krebs} \quad \mathrm{Q}$. The Krebs solution was switched from normal to $\mathrm{Ca}^{2+}$-free krebs just before agonist addition. The effects of ryanodine $\square$ were studied by inceleating tissues in $\mathrm{Ca}^{2+}-\mathbf{f r e e} \mathrm{Krebs}$ and $10 \mu \mathrm{M}$ ryanodine for one hour followed by re-introduction of normal Krebs and agonist. Values represent means \pm (S.E.M.) $n=6$. Statistical differences between means were assessed by one-way ANOVA.

- Denote signifieant differences $(p<$,05) 


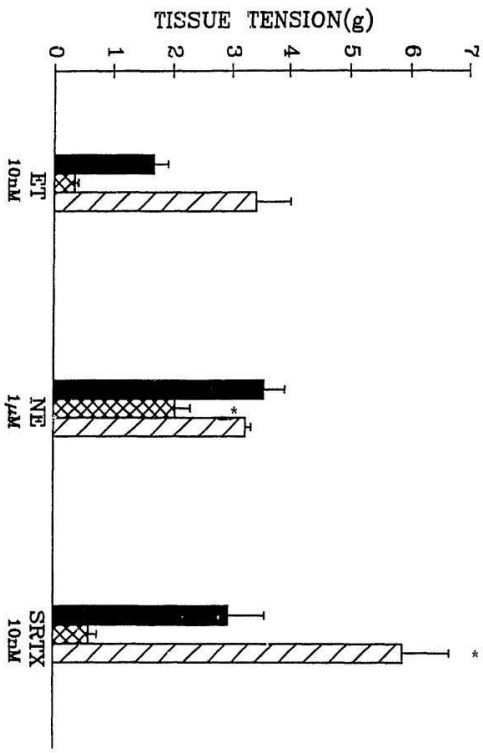


Figure 14: A comparioon of the contractile effecto induced by $10 \mathrm{nM} E T-1$, SRTX-b and $1 \mu \mathrm{M}$ NE in the rat aortic ring preparation in normal Kreba , $\mathrm{Ca}^{2+}$-free Krebu $\mathbf{E}$. The Krebs solution was switched from normal to $\mathrm{Ca}^{2+}$-free just before agonist addition. The effects of ryanodine $\square$ were studied by incubating tissues in $\mathrm{Ca}^{2+}-$ free $\mathrm{Krebs}+10 \mu \mathrm{M}$ ryanodine for one hour followed by re-introduction of normal Krebs and agonist. Values represent means \pm (S.E.M.). $(n=6)$

statistical differences between means were assessed by one-way ANOVA.

* Denote significant differences $(p<.05)$ 


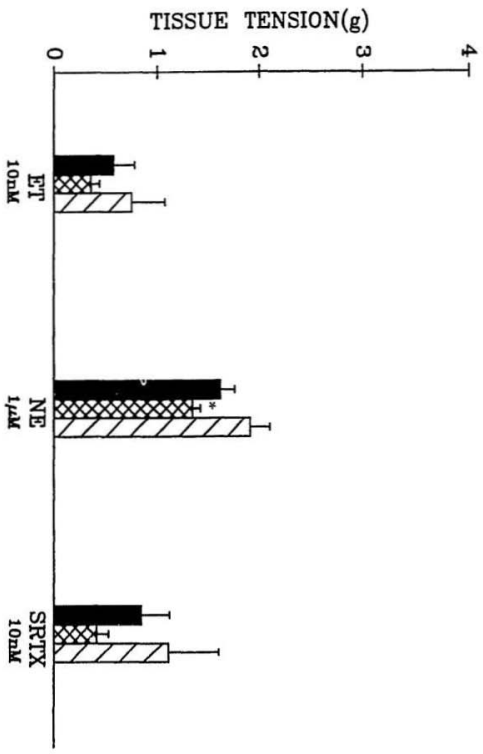




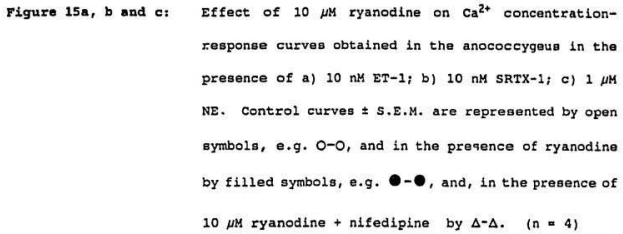


95

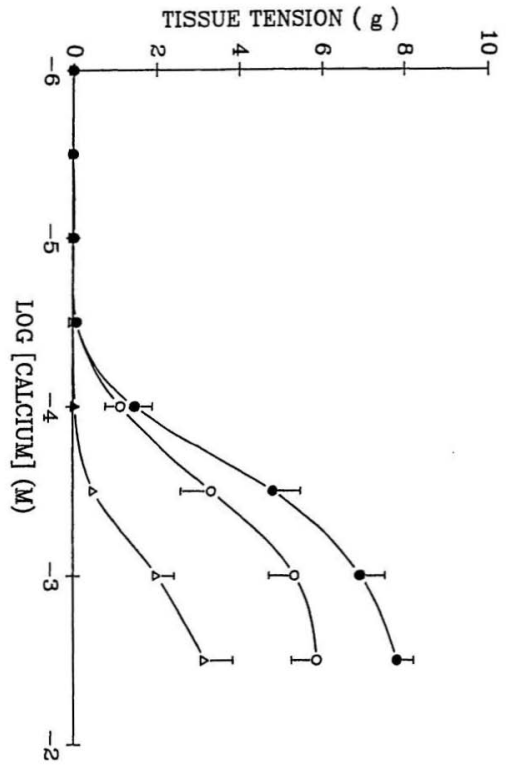

פ 


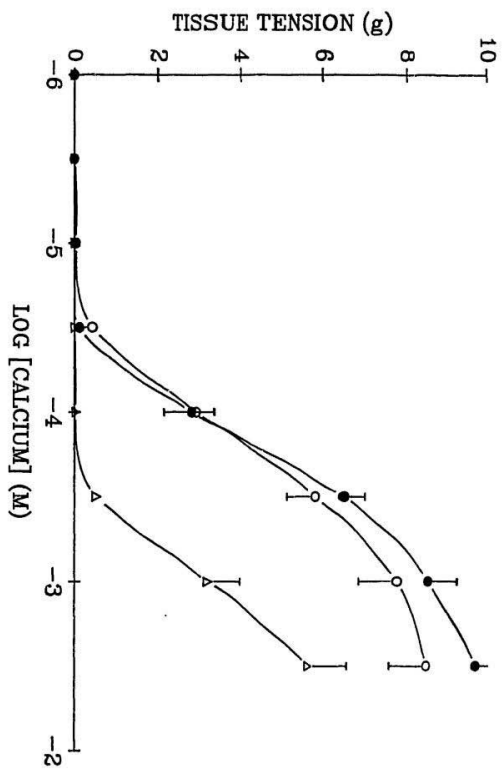

$\Xi$ 


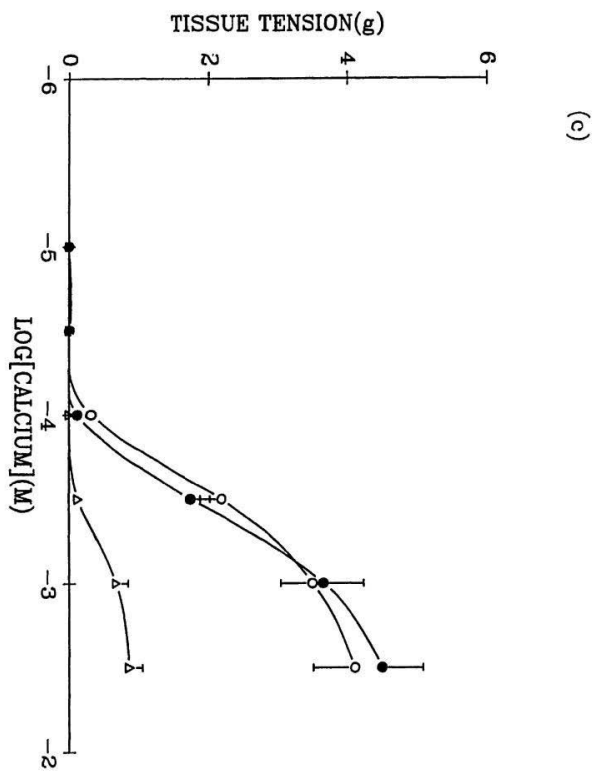


rigure $16 \mathrm{a}, \mathrm{b}$ and $\mathrm{a}$ : Effect of $10 \mathrm{mM}$ ryanodine on $\mathrm{Ca}^{2+}$ coneantrationresponse obtalned in aorta in the presence of a) 10 nM ET-1; b) $10 \mathrm{nM} \operatorname{SRTX}-1$, e) $1 \mu \mathrm{M}$ NE. Control curves \pm S.E.M. are represented by open symbols, e.g. 0-0, and, in the presence of ryanodine, by filled symbols, e.g. - - , and, in the presence of 10 $\mu M$ ryandoine + nifedipine by $\Delta-\Delta . \quad(n=4)$ 


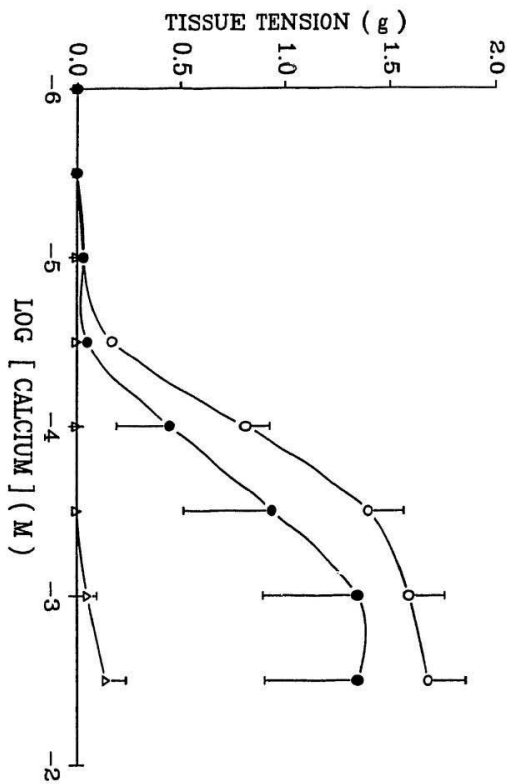

a 


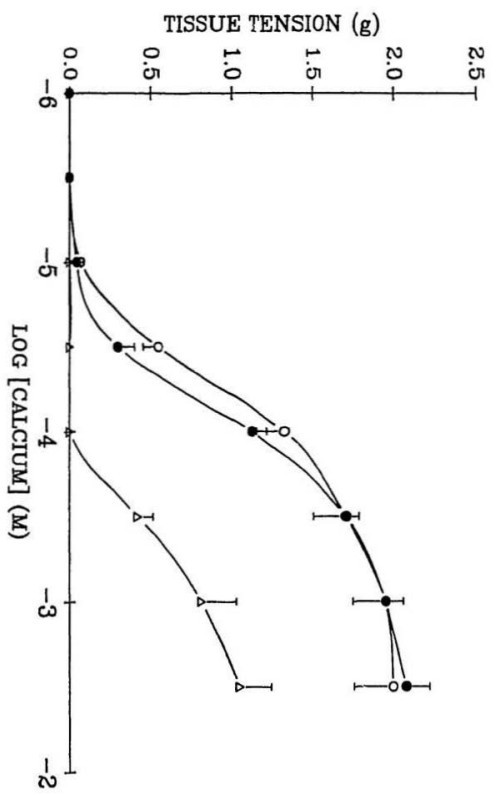

$\widehat{\sigma}$ 


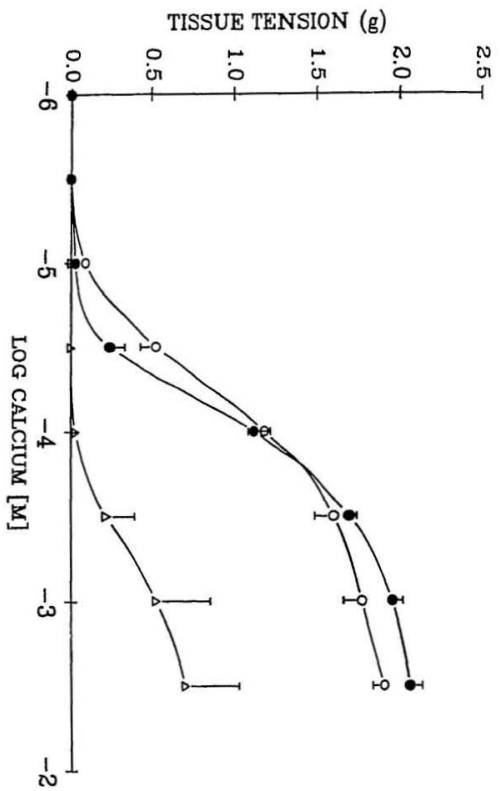

อ 
Figure 17 (a and $b$ ): Illustration in : a) anococcygeus and b) aorta that ropeated stimulation with $\mathrm{NE}$, in a $\mathrm{Ca}^{2+}$-free $\mathrm{Krebs}$ buffer can reduce the tissue response to a certain basal level beyond which further attenuation is not possible. 


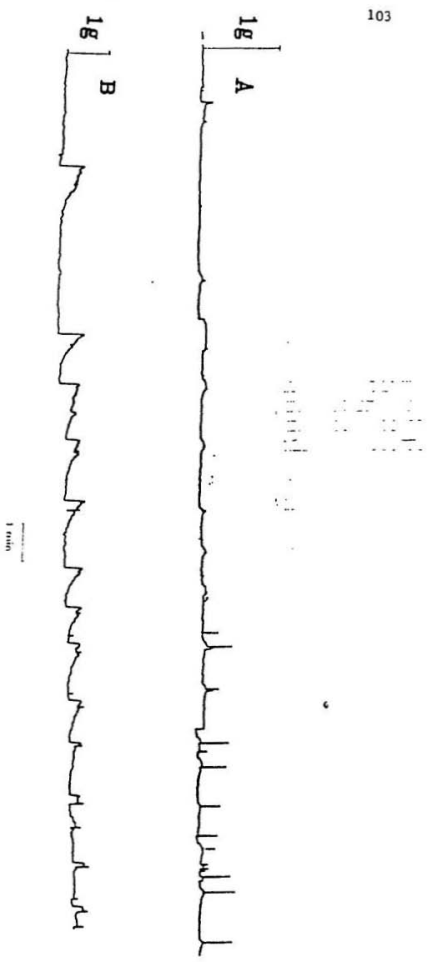


Figure $18 \mathrm{a}, \mathrm{b}$ and $\mathrm{C}:$ Effect of $\mathrm{NE}-$ induced $\mathrm{Ca}^{2+}$ depletion on calcium coneontration-responac obtained in anoeoecygous in the presence of a) $10 \mathrm{nM} \mathrm{ET-1;} \mathrm{b)} 10 \mathrm{nM} \mathrm{SRTX-b;} \mathrm{c)} 1$ $\mu$ M NE. Control curves \pm S.E.M. are represented by open symbols, e.g. O-O, and after NE depletion by filled symbols, e.g. - and, in the presence of 10 $\mu \mathrm{M}$ nifedipine, response in by $\Delta-\Delta . \quad(\mathrm{n}=4)$ 


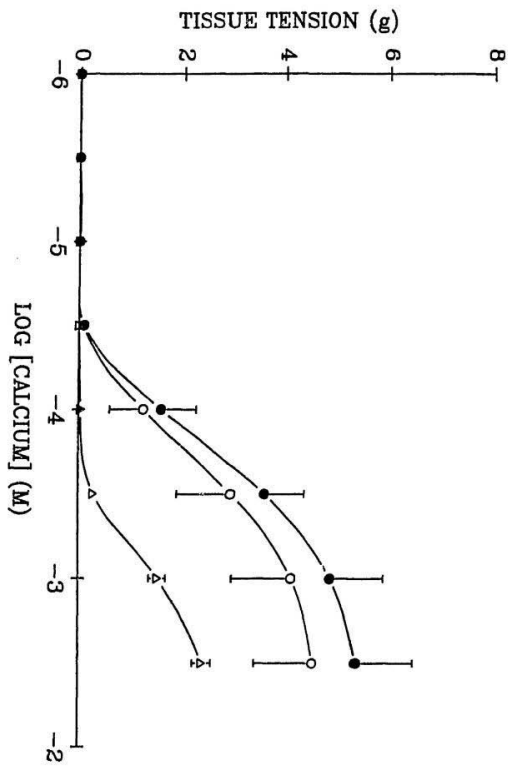

(2) 


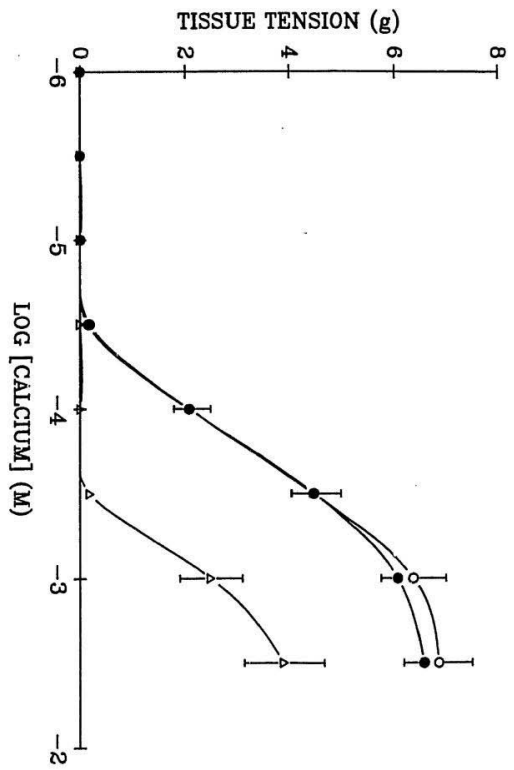

$\sigma$ 


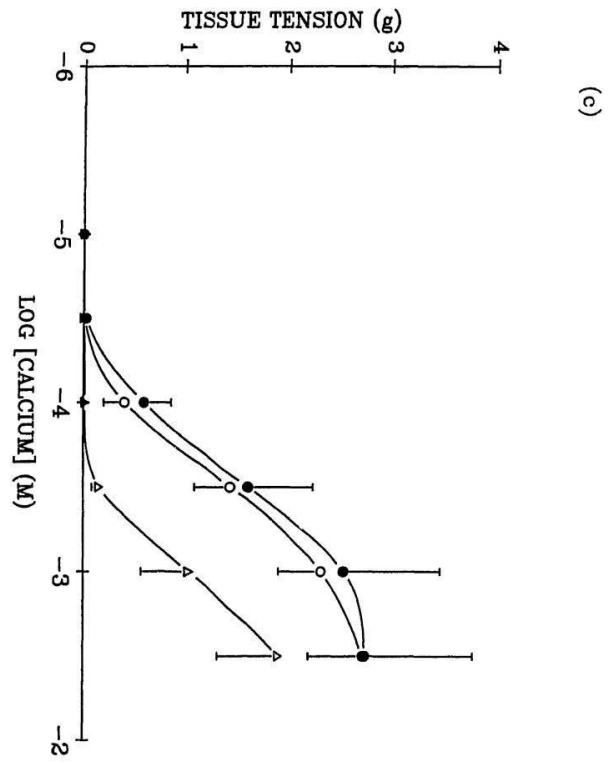


Figure 19a, b and c: Effect of $\mathrm{NE}-$ induced $\mathrm{Ca}^{2+}$ depletion on $\mathrm{Ca}^{2+}$ concentration-response curves obtained in the aorta in the presence of a) $10 \mathrm{nM} \mathrm{ET-1}$; b) $10 \mathrm{nM} \mathrm{SRTX-b;}$ c) 1 MM NE. Control curves \pm S.E.M. are represented by open symbols, e.g. $0-0$ and after NE depletion by filled symbols, e.g. - and, in the presence of 10 $\mu$ M nifedipine, by $\Delta-\Delta . \quad(n=4)$ 


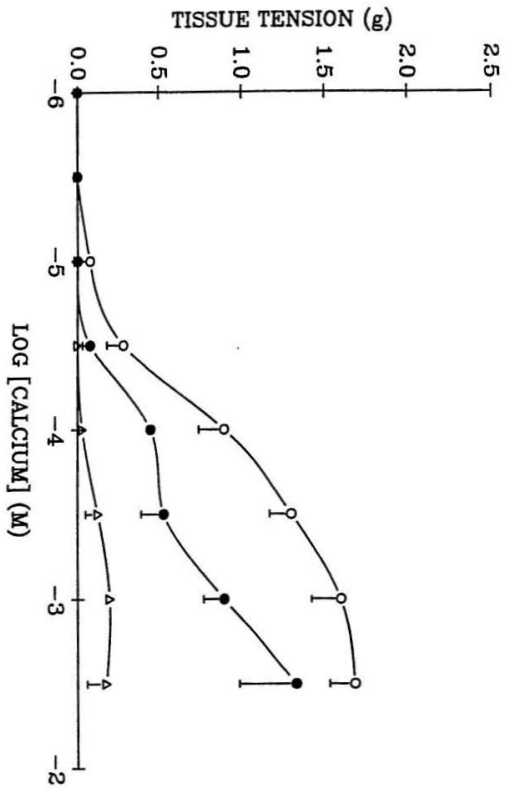

ฮ 


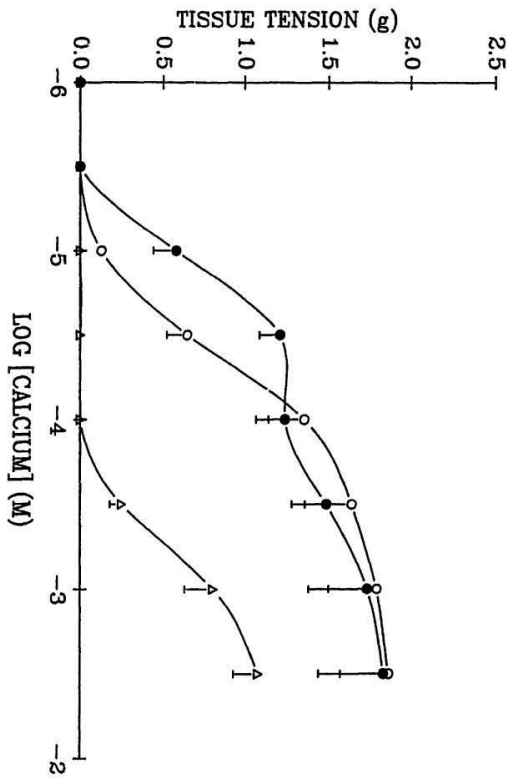

$\tilde{\sigma}$ 


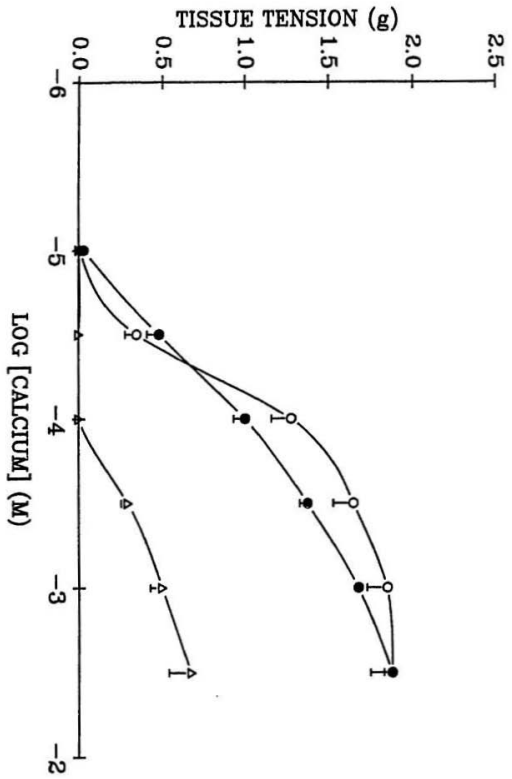

ล 
Figure 20a, b and e: Effect of sequential $\mathrm{NE}$ and ryanodine induced $\mathrm{Ca}^{2+}$ depletion on $\mathrm{Ca}^{2+}$ concentration-response curves obtained in the anococcygeus in the presence of a) $10 \mathrm{nM} \mathrm{ET}-1$; b) $10 \mathrm{nM} \operatorname{SRTX}-b$; c) $1 \mu \mathrm{M} \mathrm{NE}$. Control curves \& S.E.M. are represented by open symbols, e.g. $\mathrm{O}-\mathrm{O}$ and after $\mathrm{NE}$ and ryanodine depletion by filled symbols, e.g. -10 and, in the presence of 10 $\mu M$ nifedipine, by $\Delta-\Delta . \quad(n=4)$ 


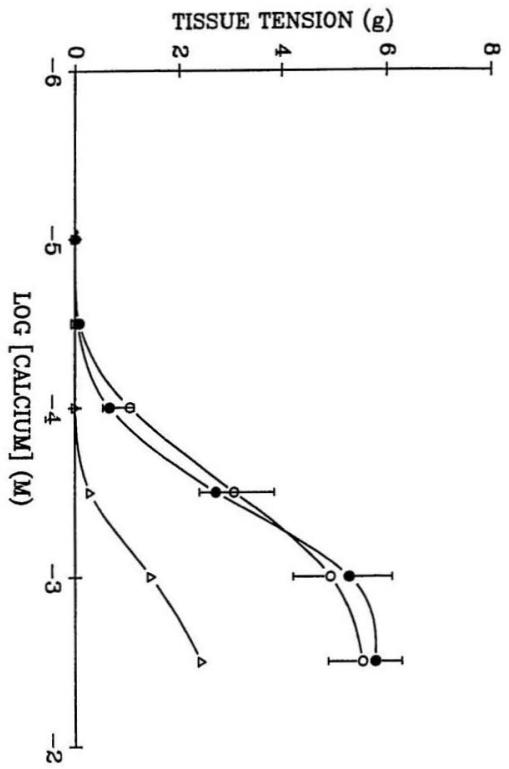

ฮ 


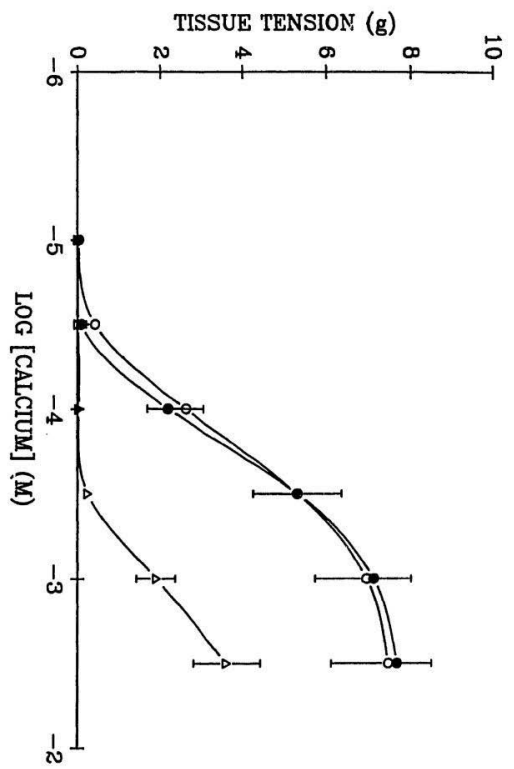

 


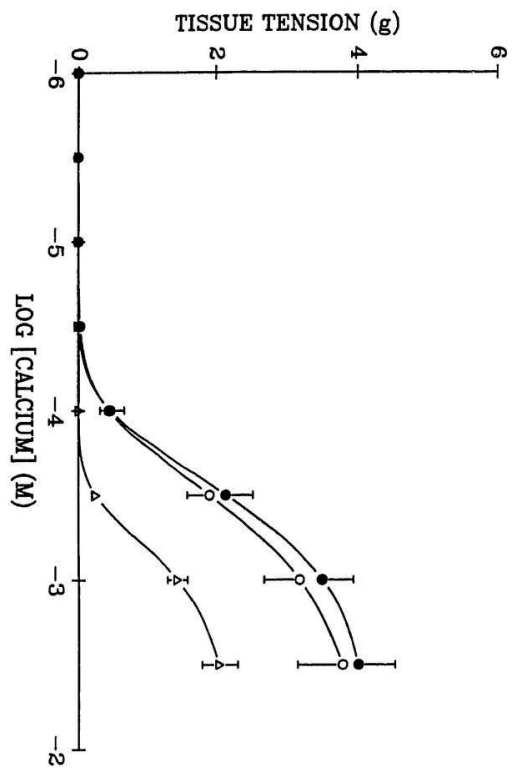

อ 


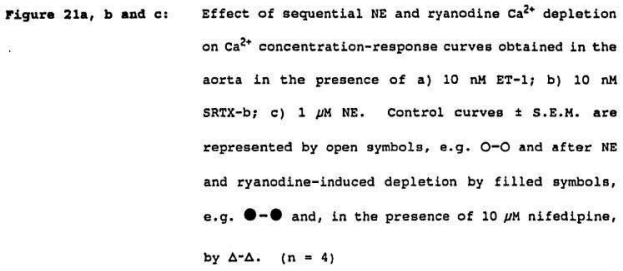




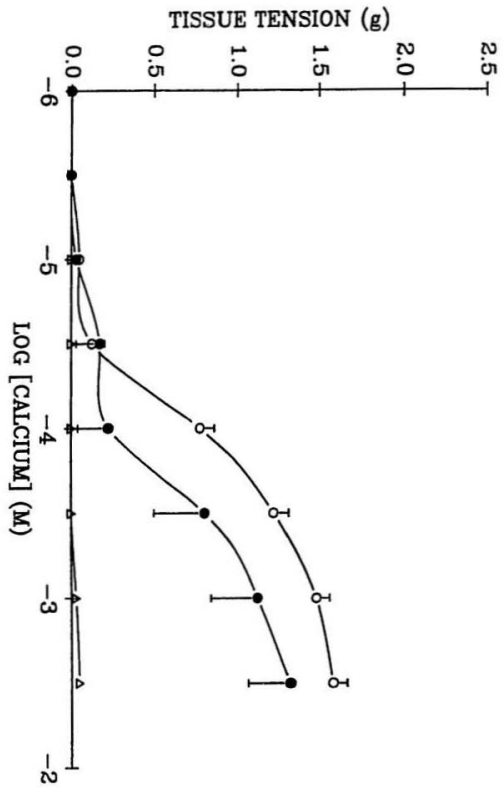

อ 


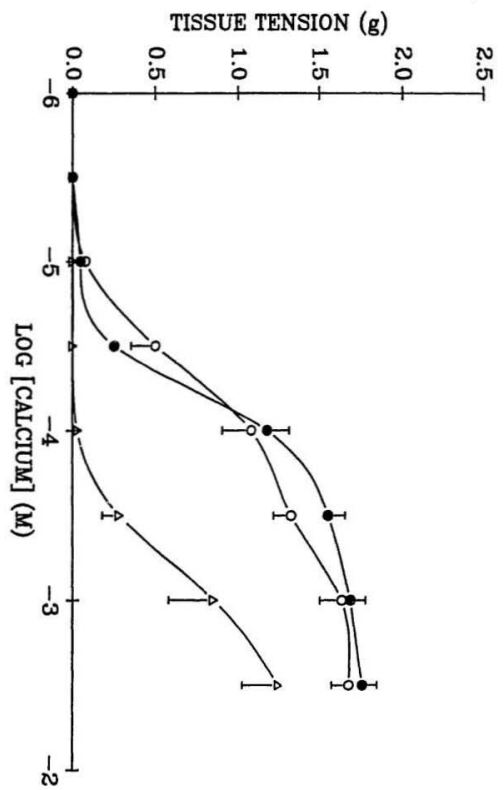

o 


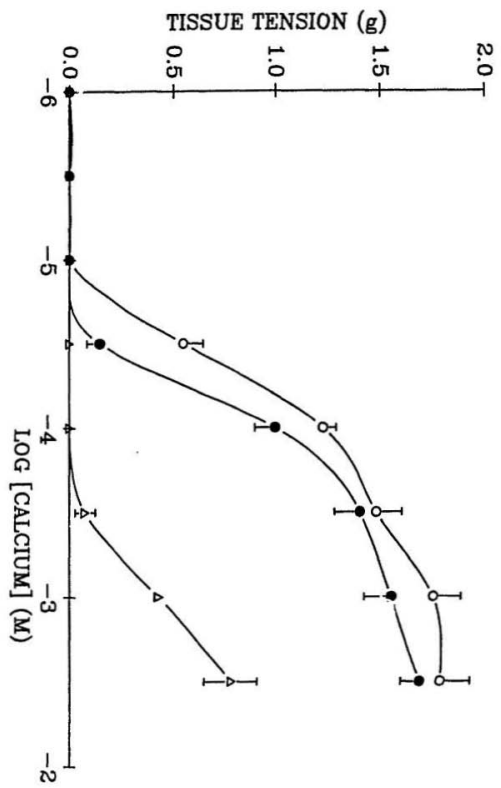

อ 
Figure 22a, b and c:

Comparative affecte of a) $10 \mu \mathrm{M}$ eyanodine; b) $10 \mu \mathrm{M}$ ryanodine plus $0.1 \mathrm{mM}$ caffeine; c) $10 \mu \mathrm{M}$ ryanodine + $10 \mathrm{nM}$ SRTX-b respectively on $\mathrm{Ca}^{2+}$ concentrationresponse curves obtained in the anococcygeus. Control eurves \pm S.E.M. are represented by open symbols e.g. $0-0$ and after treatment by $a, b$ and $c$ above, by filled symbols e.g. - Note that $10 \mathrm{nM}$ SRTX-b is administered after $\mathrm{Ca}^{2+}$ depletion in $a$ and b. $(n=4)$ 


\section{\% MAXIMUM CONTROL}

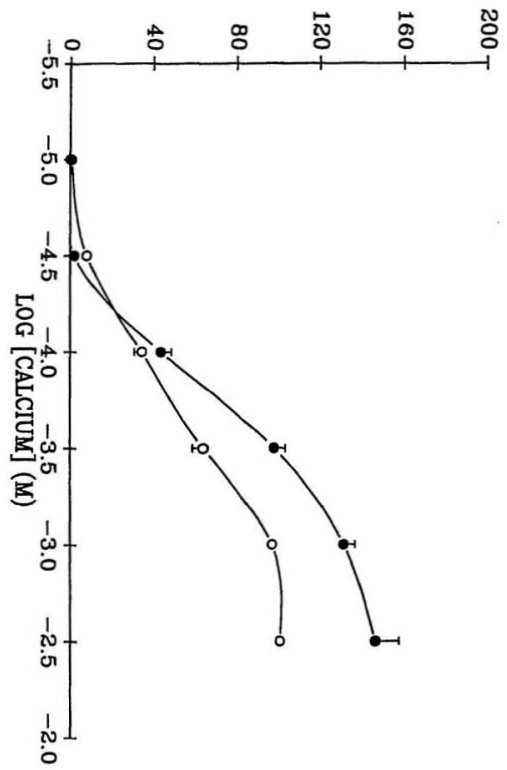

$\bar{e}$ 


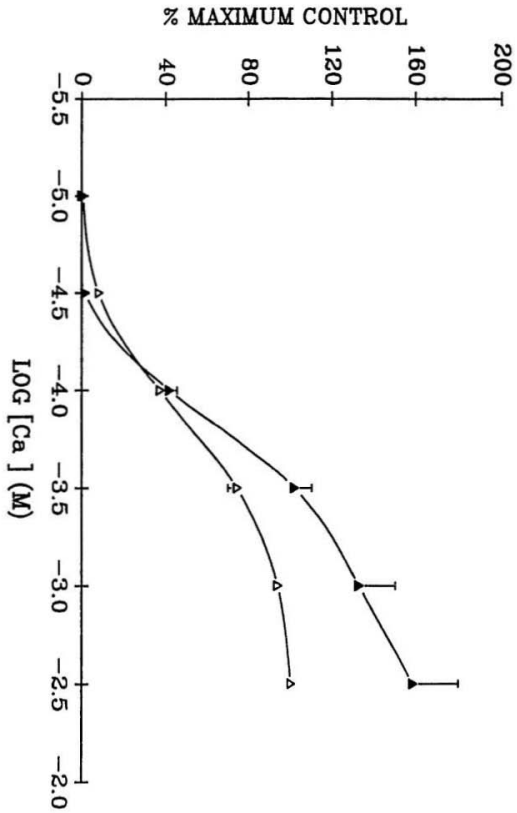

$\widehat{\sigma}$ 


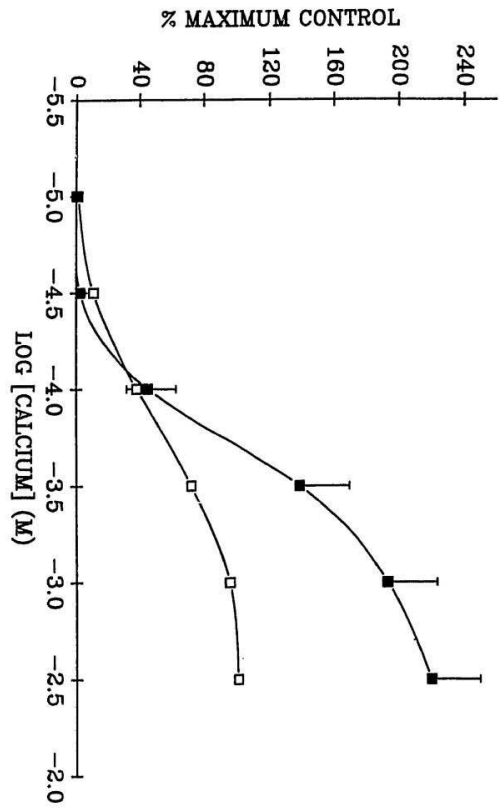

อ 
Figure 23a, b and c: comparative effects of a) $10 \mu \mathrm{M}$ ryanodine; b) $10 \mu \mathrm{M}$ ryanodine plus $0.1 \mathrm{mM}$ caffeine; c) $10 \mu \mathrm{M}$ ryanodine + $10 \mathrm{nM} \mathrm{ET}-1$ concurrently on $\mathrm{Ca}^{2+}$ concentrationresponse obtained in the anococcygeus. control curves \pm S.E.M. are represented by open symbols e.g. $0-0$ and after treatment by $a, b$ and $c$ above, by filled symbols e.g. - Note that $10 \mathrm{nM} \mathrm{ET-1}$ was administcred after $\mathrm{Ca}^{2+}$ depletion in a and b. (n =4) 


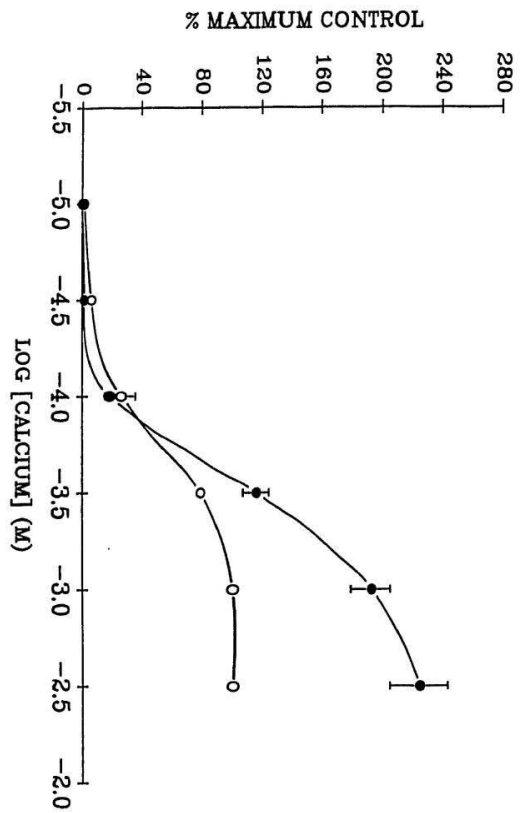




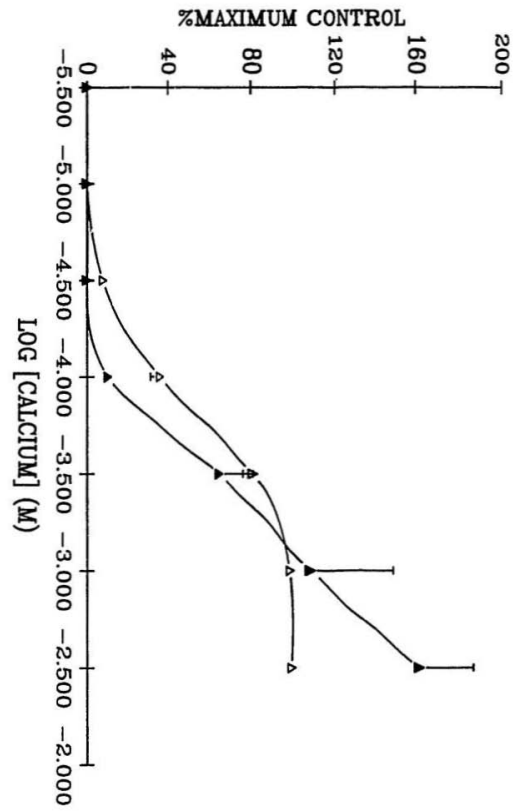

$\widehat{\sigma}$ 


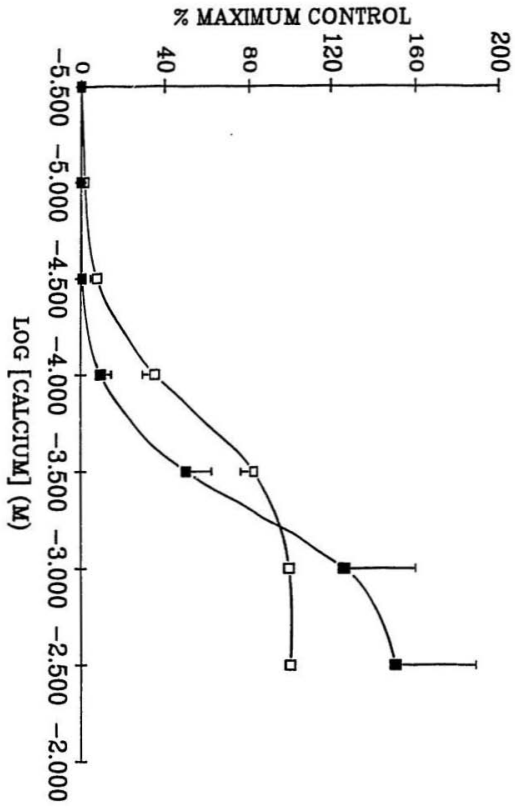

$\widehat{a}$ 

ryanodine plus $0.1 \mathrm{mM}$ caffeine; c) $10 \mu \mathrm{M}$ ryanodine + $10 \mathrm{nM}$ SRTX-b concurrently on $\mathrm{Ca}^{2+}$ concentrationresponse curves obtained in the aorta. Control curves \pm S.E.M. are represented by open aymbols e.g. $0-0$ and after treatment by $a, b$ and $c$ above, by filled symbols e.g. -O. Note that $10 \mathrm{nM}$ SRTX-b was administered after $\mathrm{Ca}^{2+}$ depletion in a and b. in =4) 


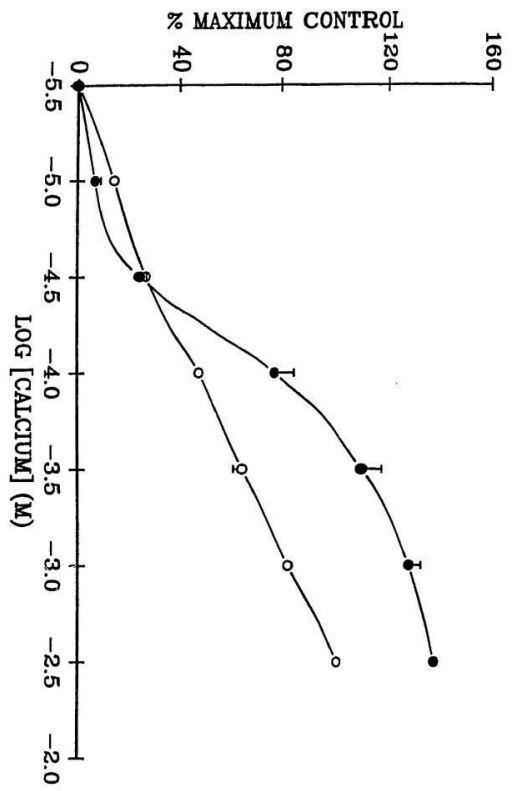

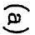




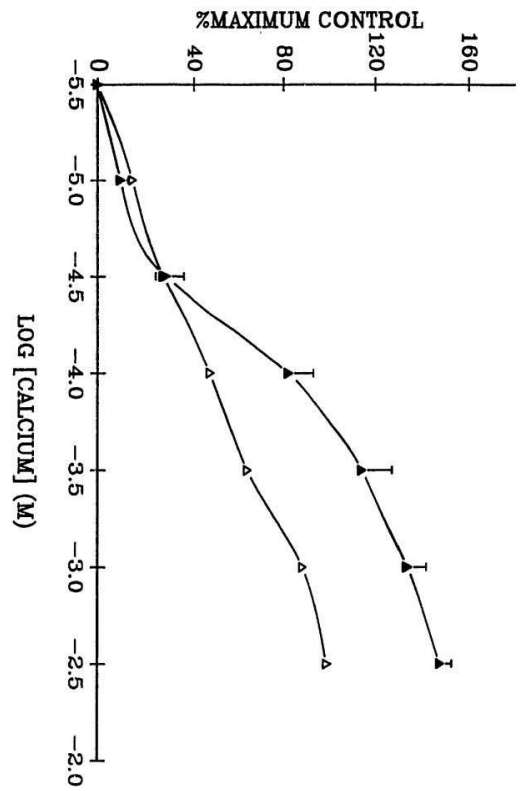

$\sigma$ 


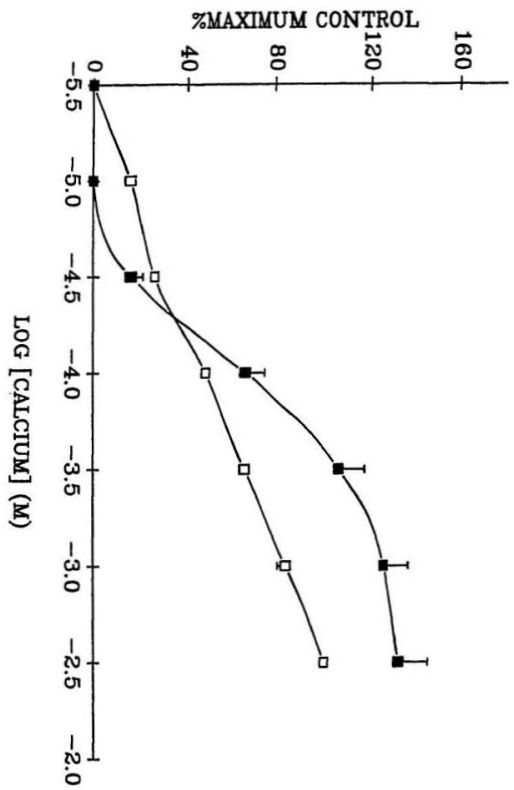

ก 
Figure 25a, b and e: Comparative effects of a) $10 \mu \mathrm{M}$ ryanodine; b) $10 \mu \mathrm{M}$ ryanodine plus $0.1 \mathrm{mM}$ caffelne; c) $10 \mu \mathrm{M}$ ryanodine + $10 \mathrm{nM}$ ET-1 concurrently on $\mathrm{Ca}^{2+}$ concentrationresponse curves obtained in the aorta. Control curves \pm S.E.M. are represented by open vymbols e.g. $0-0$ and after treatment by $a, b$ and $c$ above, by filled symbols e.g. - Note that $10 \mathrm{nM}$ SRTX-b was administered after $\mathrm{Ca}^{2+}$ depletion in a) and b). (n (4) 


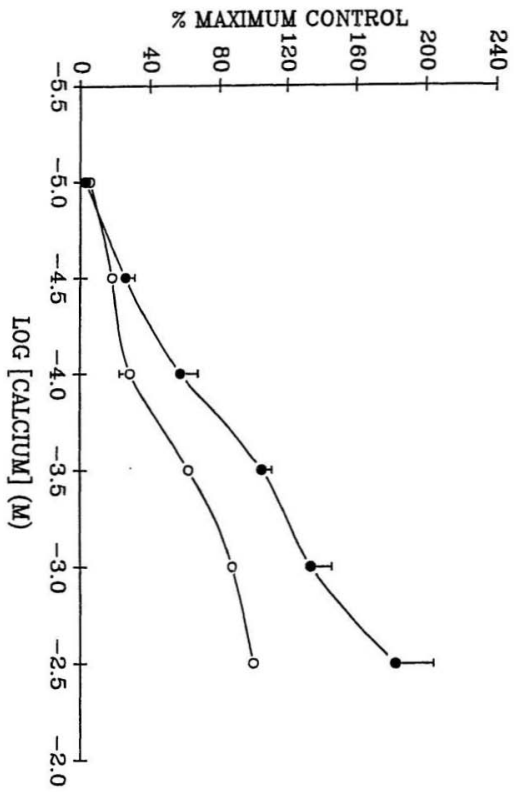

อ 


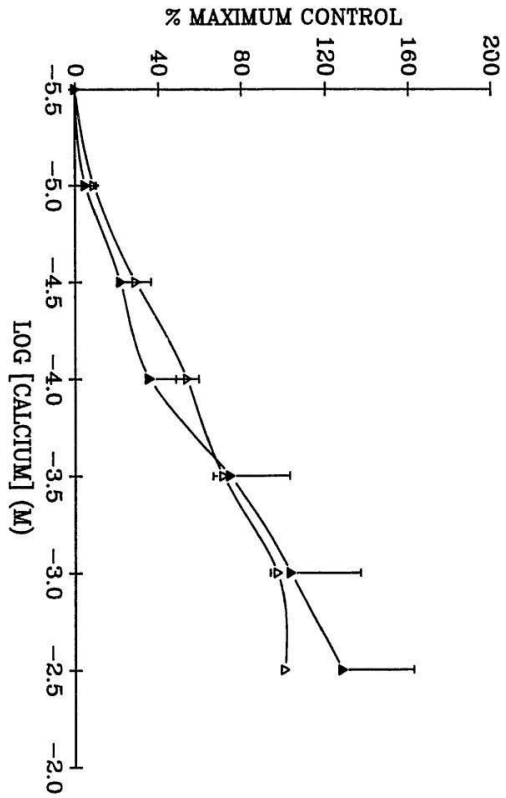

$\widetilde{\sigma}$ 


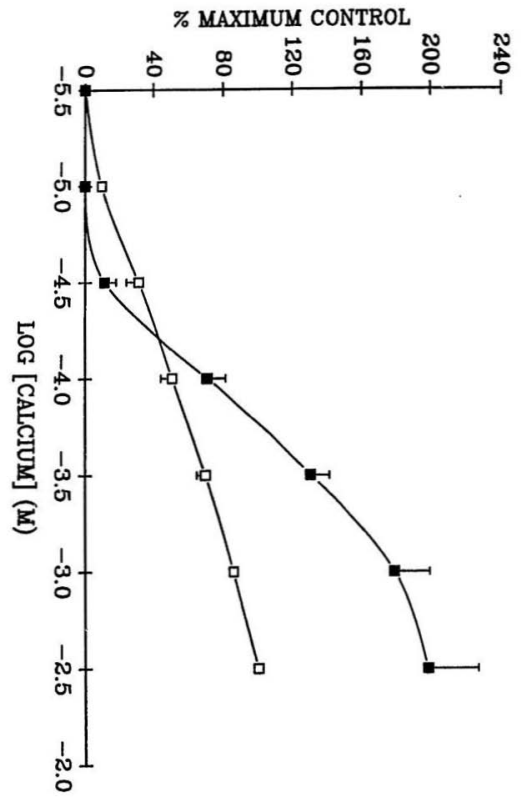

อ 

NE on the Bay K 8644 concentration-remponse curve obtained in anococcygeus. Control curves \pm S.E.M. are represented by open symbols e.g. 0-0 and after application of $a, b$ and $c$ above, by filled aymbola e.g. -O. $(n=4)$ 


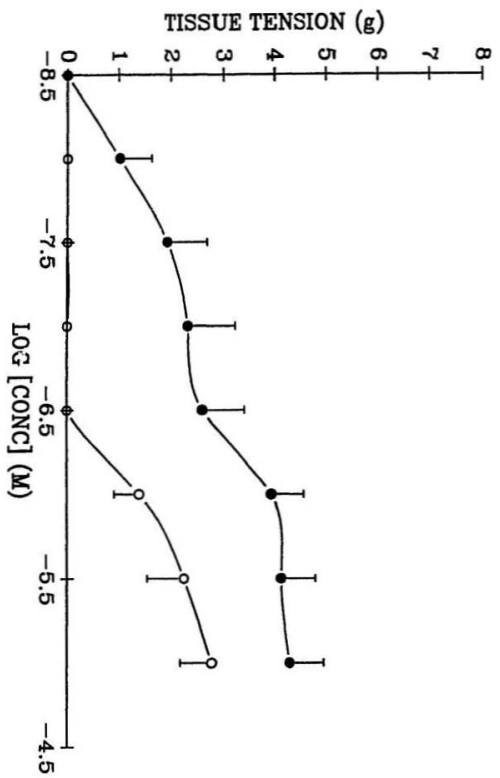

ตำ 


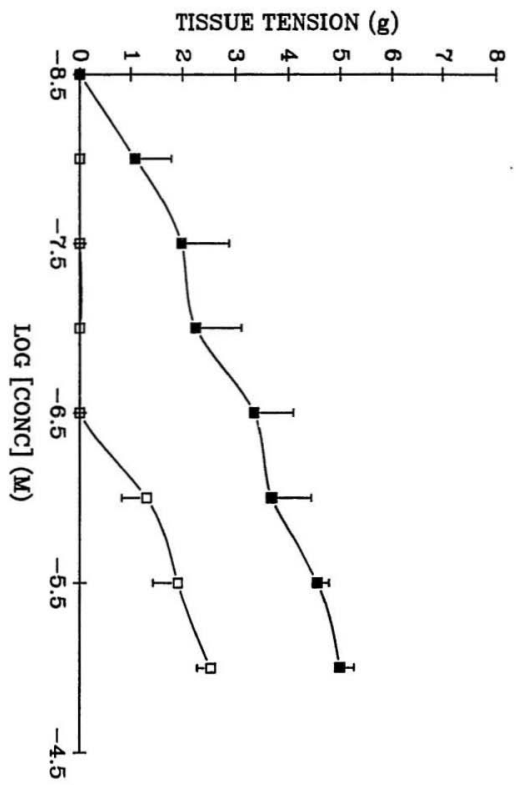

$\widehat{\sigma}$ 


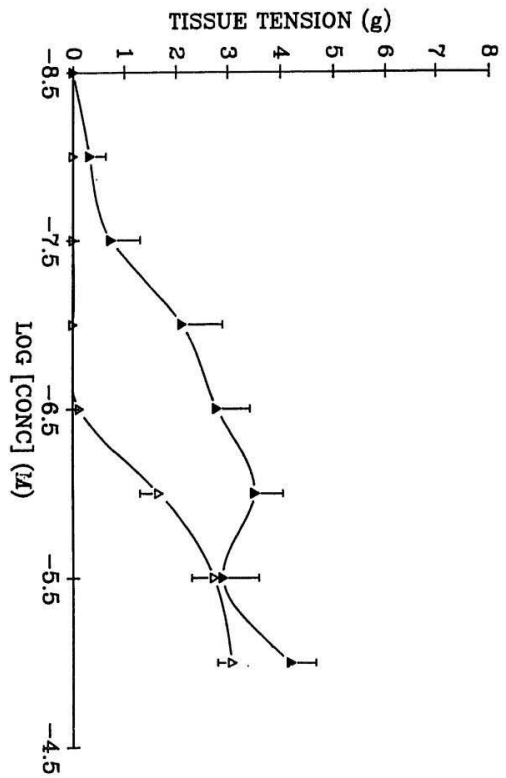

อ 
Figure 27: Illustration of the concentration-independent response of the anococcygeus (a) in contrast to the concentration-dependent response of the aorta (b) to Bay $\mathrm{x} 8644$. 


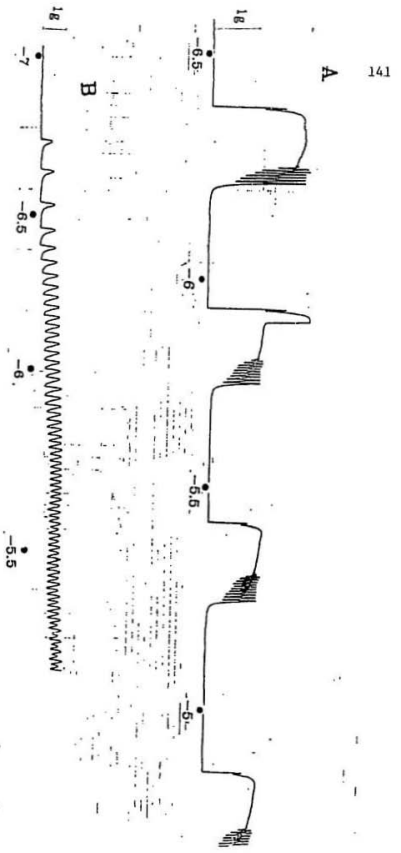


Figure 28a, b and $c$ : Effect of the presence of a) $1 \mathrm{nM} \mathrm{ET-1;}$ b) $1 \mathrm{nM}$ SRTX-b and c) $100 \mathrm{nM} N E$ on Bay K 8644 concentrationresponse curves obtained In the aorta. Control eurves \pm S.E.M. are represented by open symbols e.g. 0-O and after application of $a, b$ and $e$ above by filled oymbols e.g. -.$(n=4)$ 


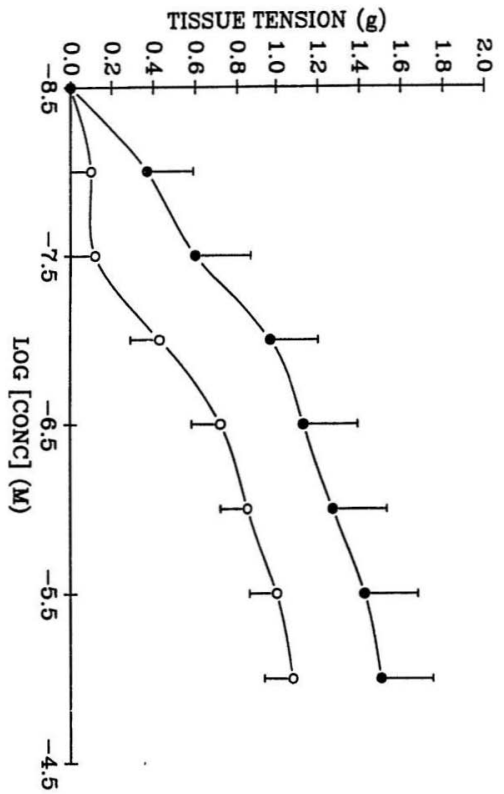

ตู 


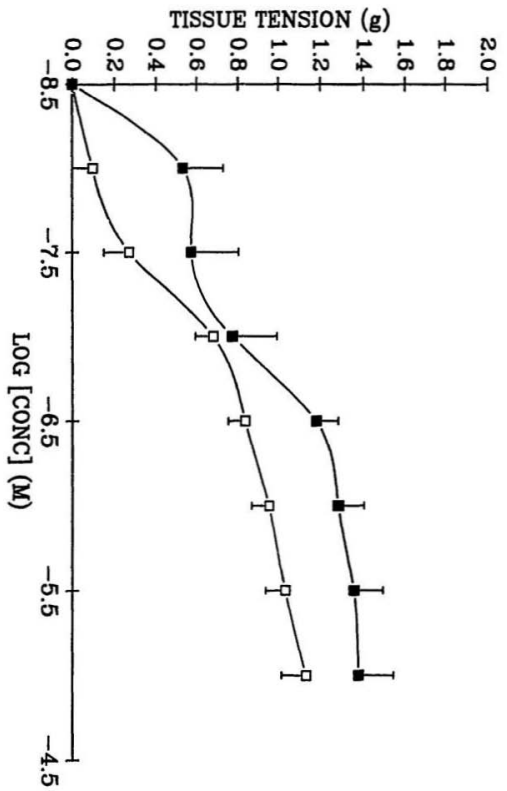

$\widetilde{\sigma}$ 


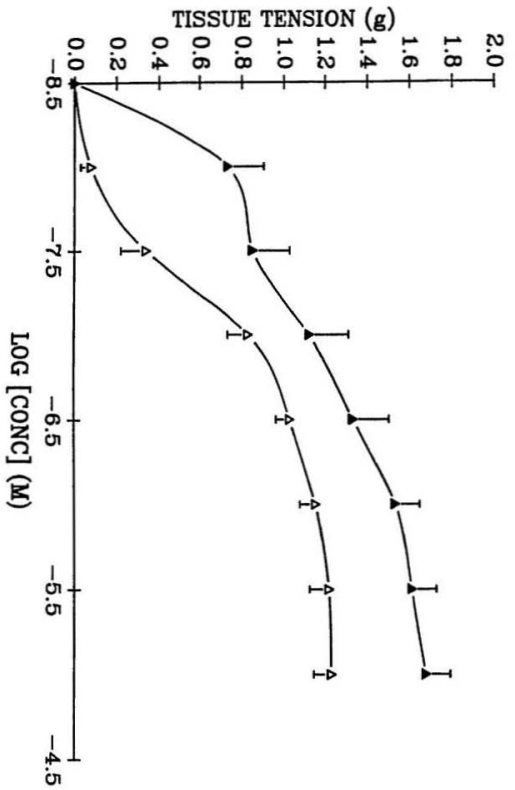

ล 


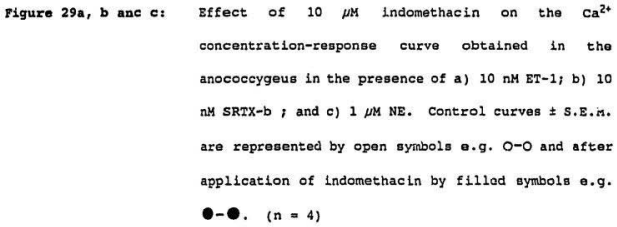




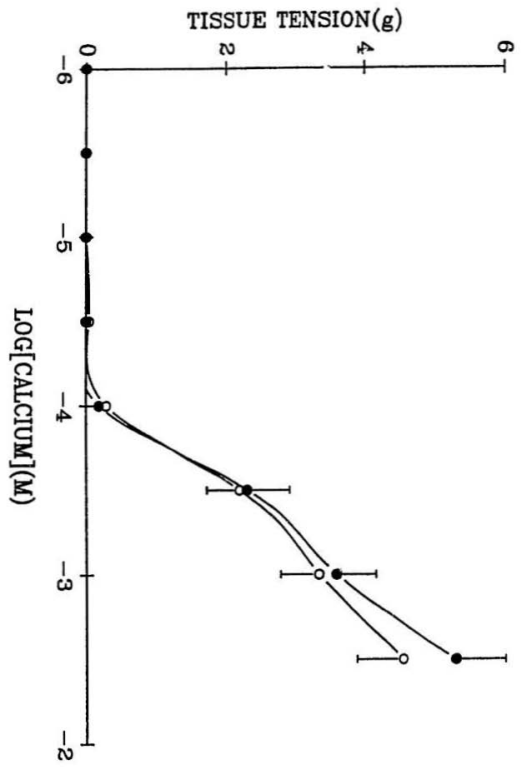

ฮ્ 


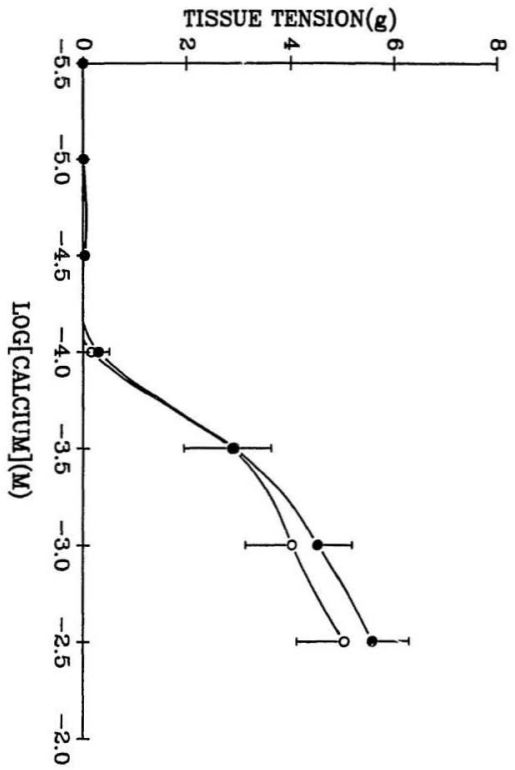

$\sigma$ 


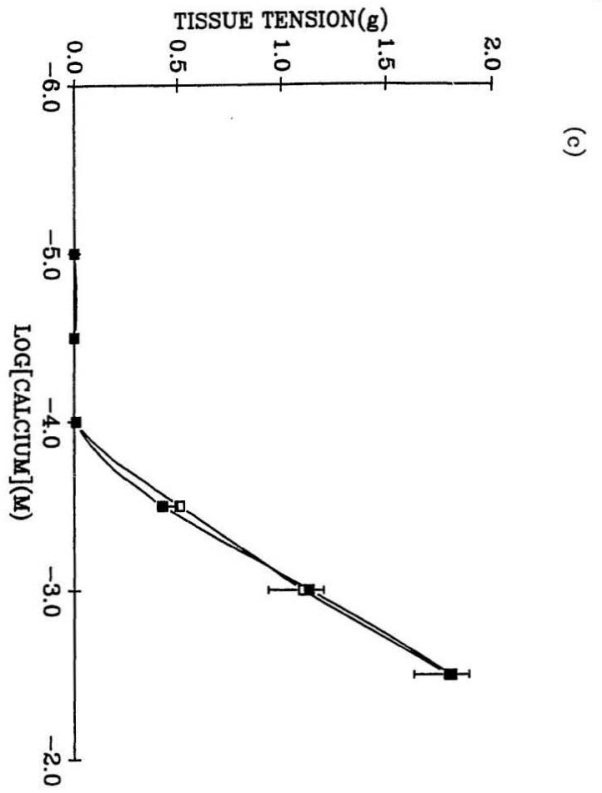


Figure $30 \mathrm{a}, \mathrm{b}$ and $\mathrm{c:}$ Effect of $10 \mu \mathrm{M}$ indomethacin on the $\mathrm{Ca}^{2+}$ concentration-response curve obtained in the aorta in the presence of a) $10 \mathrm{nM} \mathrm{ET-1;}$ b) $10 \mathrm{nM}$ SRTX-b, and c) $1 \mu \mathrm{M}$ NE. Control curves \pm S.E.M. ara represented by open symbols e.g. 0 - 0 and after application of indomethacin by filled symbols e.g. -) $(n=4)$ 


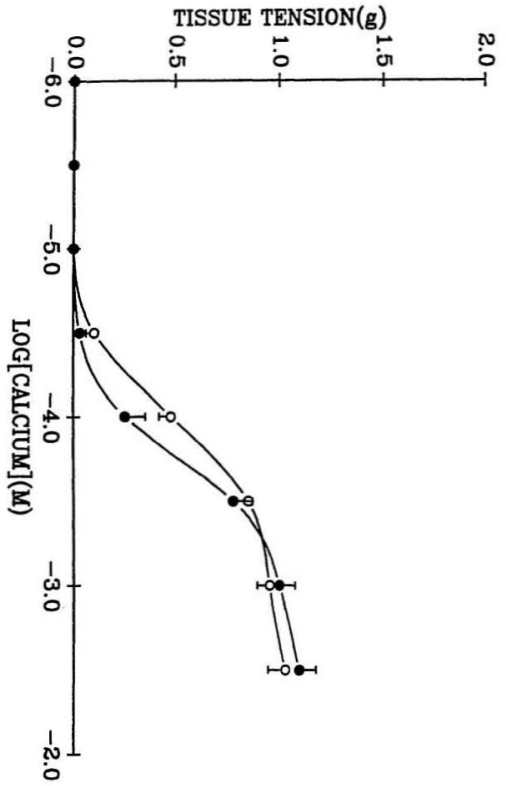

ฮ 


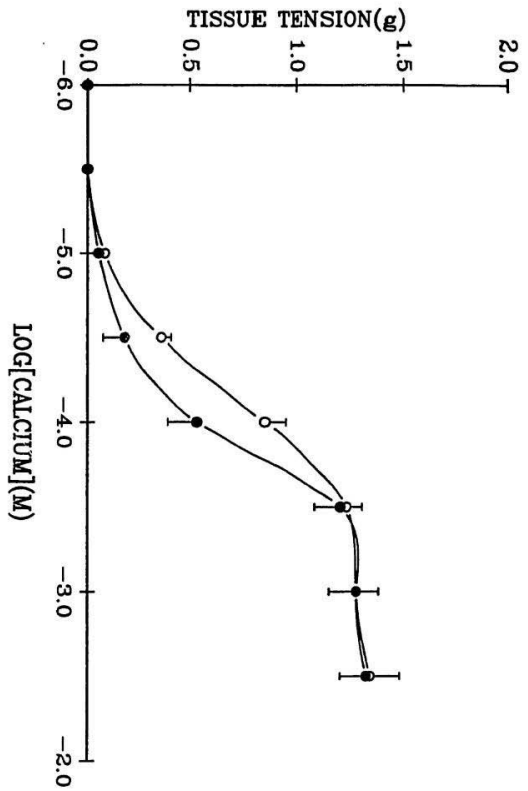

$\sigma$ 


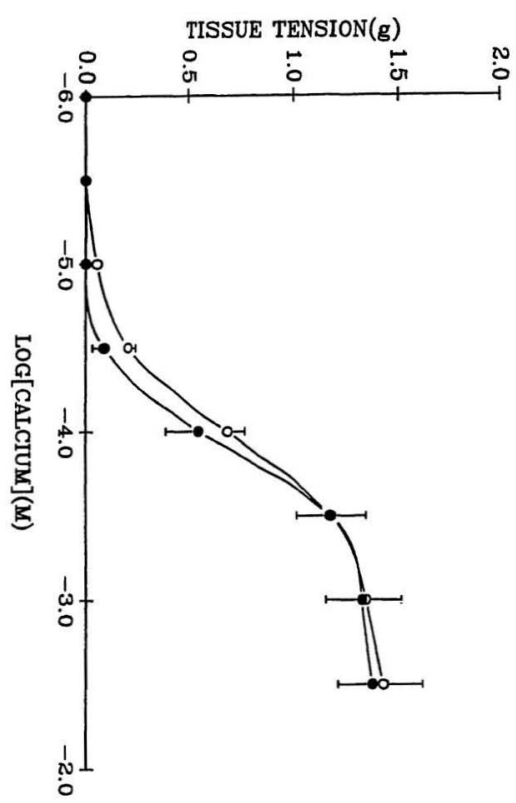

ล 


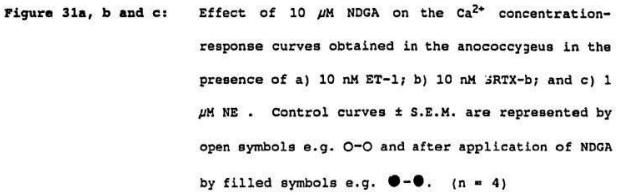




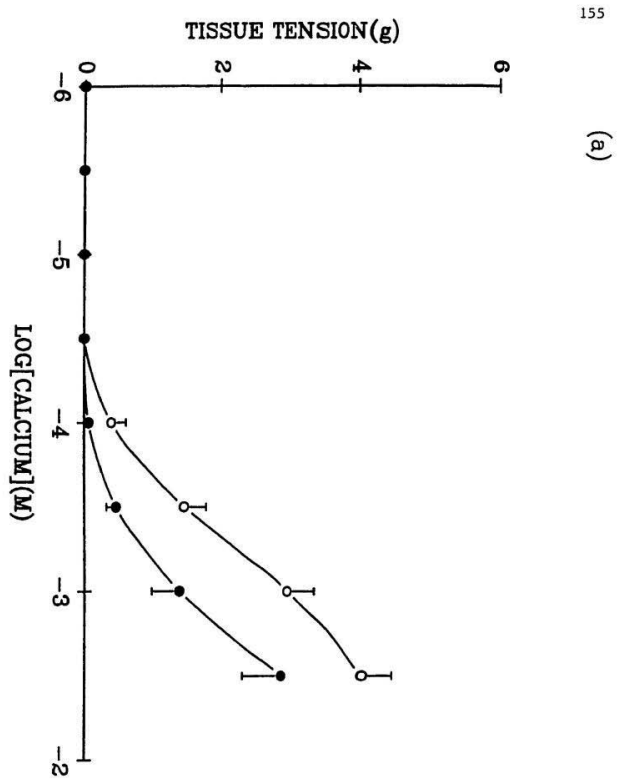




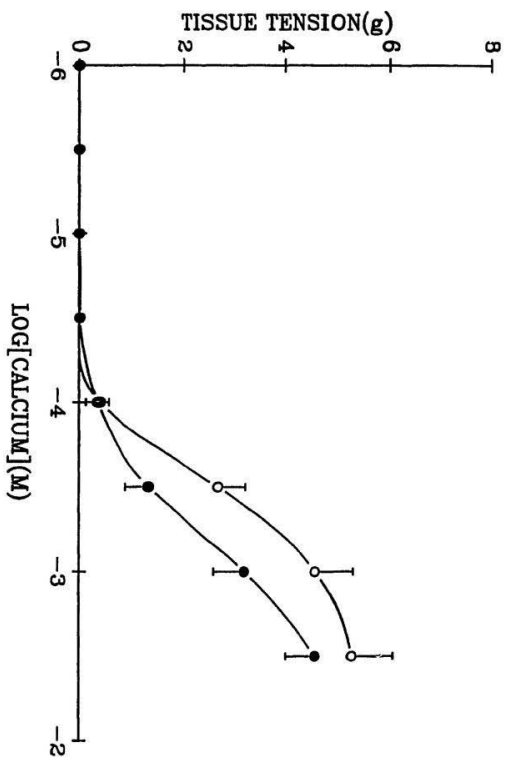

$\widehat{\sigma}$ 


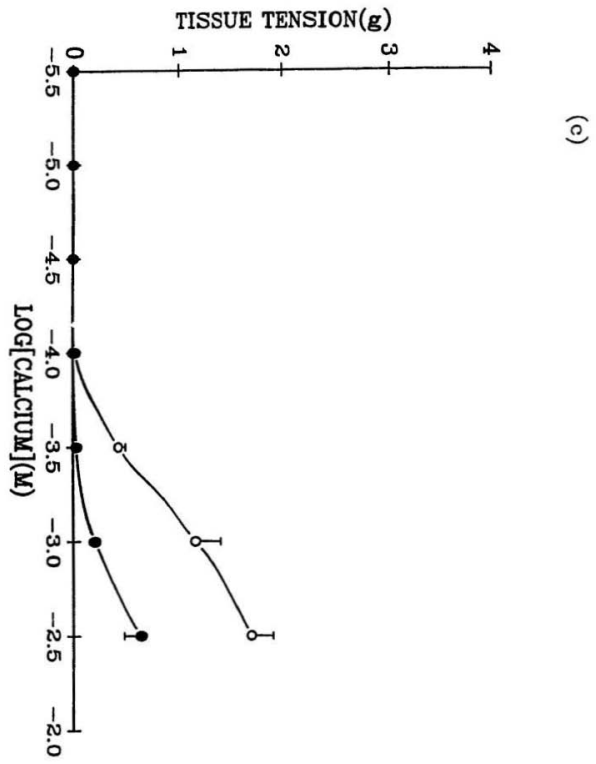




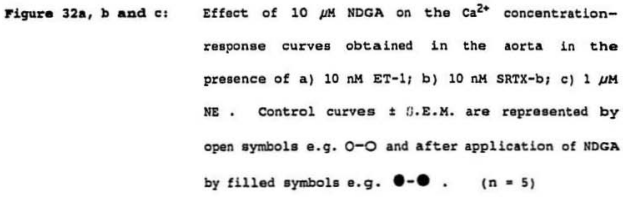




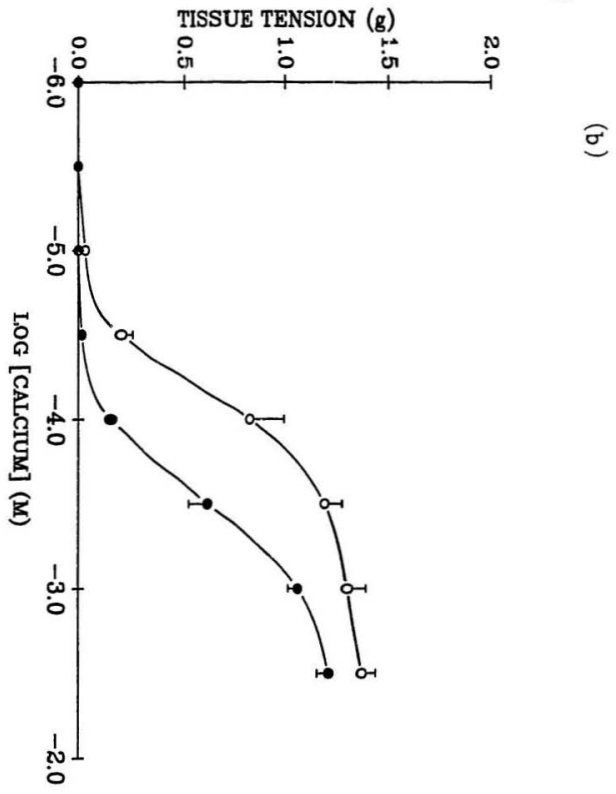




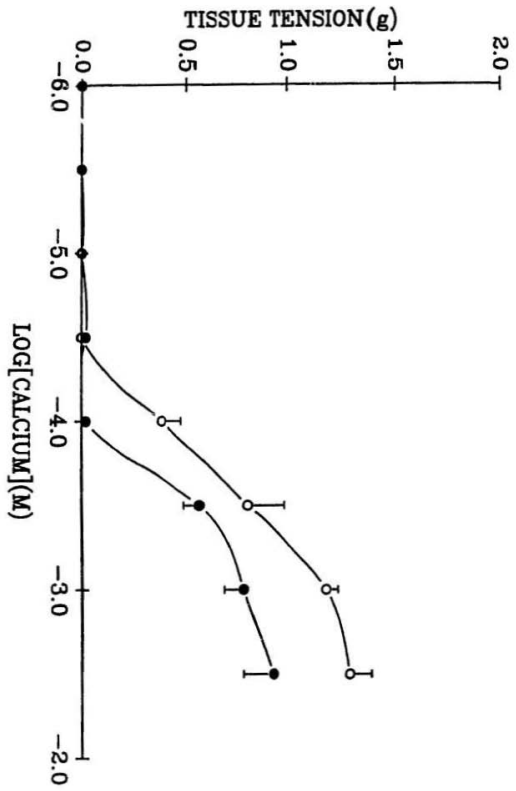

อ 


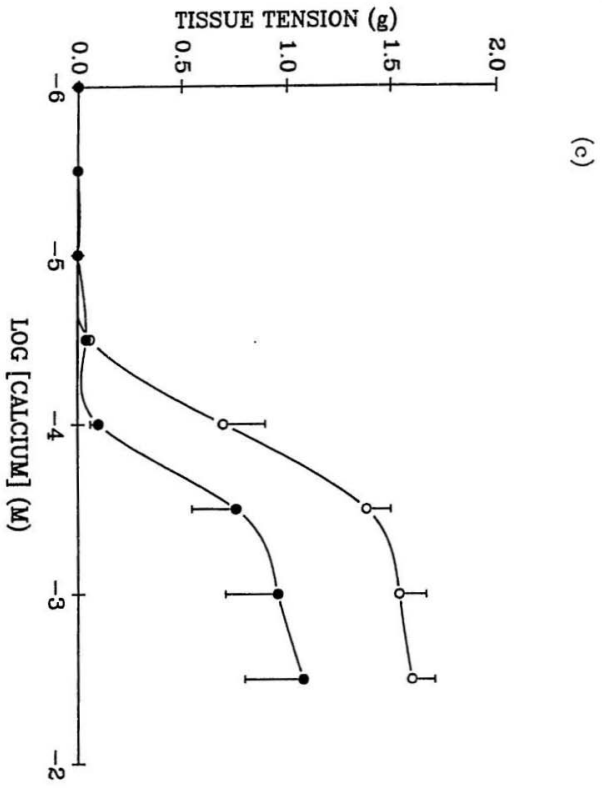


Figure 33 (a and b): a) Effect of $10 \mu \mathrm{M}$ NDGA on agonist concentrationresponse curves in the anococcygeus to: - i) ET-1 0-0; ii) $\mathrm{NE} \Delta-\Delta$; iii) $\mathrm{Ca}^{2+}$ concentration-responge curveg in the presence of $50 \mathrm{mM} \mathrm{K} \mathrm{K}^{+} \square-\square$.

b) Effect of $10 \mu \mathrm{M}$ NDGA on agonist concentrationzesponse curves in the anoceccygeus to :- i) SRTX-b $\nabla=\nabla$ ii) $\mathrm{NE}$ O-O; iii) $\mathrm{Ca}^{2+}$ concentration-reaponse curves in the presence of $50 \mathrm{mM} \mathrm{K} \mathrm{K}^{+} \square-\square$. Control curves = S.E.M. are represented by open symbols, e.g. $0-O$ and after the application of NDGA by filled symbols, e.g. -0. $(n=6)$ 


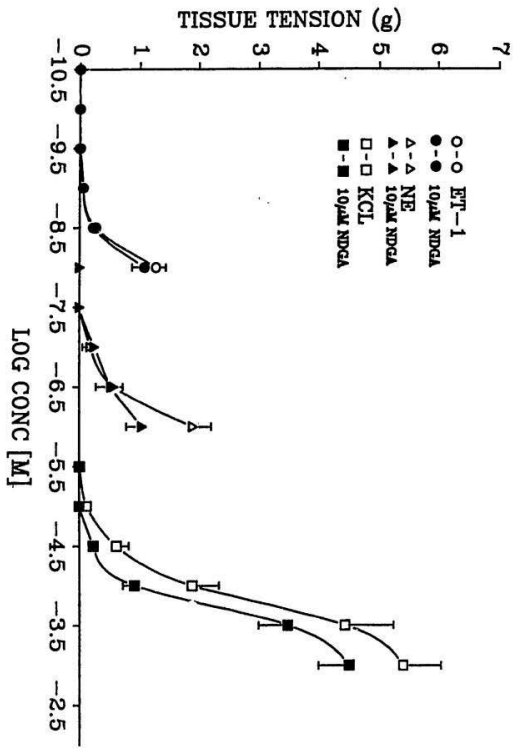




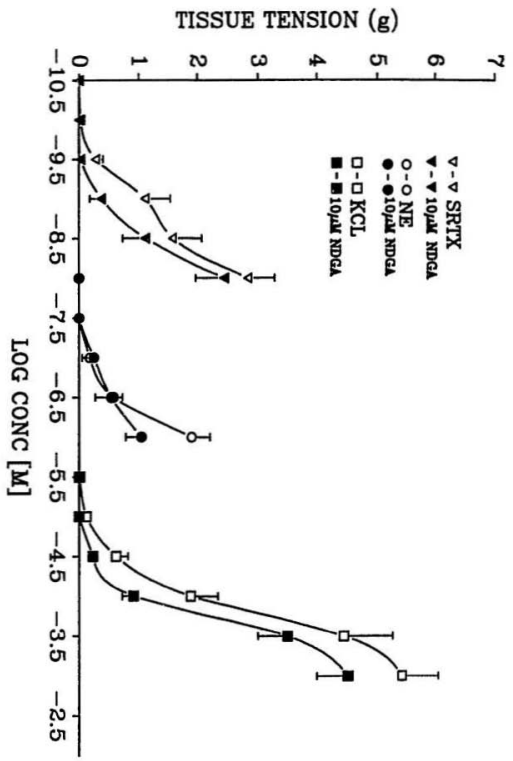


a) Effect of $10 \mu \mathrm{M}$ NDGA on agonlst concentrationresponge curvas in the aorta to :- 1) ET-1 0-0; 1i) NE $\Delta-\Delta_{i}$ ili) $\mathrm{Ca}^{2+}$ concentration-response curves in the presence of $50 \mathrm{mM} \mathrm{K}^{+} \quad \square-C$.

b) Effect of $10 \mu \mathrm{M}$ NDGA on agonist concentrationresponse curves in the aorta to :- 1) SRTX-b $\nabla-\nabla$; ii) $\mathrm{NE} \Delta-\Delta$; iii) $\mathrm{Ca}^{2+}$ concentration-zesponse curves in the presence of $50 \mathrm{mH} \mathrm{K}^{+} \square-\square$. Control curves $=$ S.E.M. are represented by open symbols, e.g. O-O and after application of MDGA by filled symbols, e.g. $-0 .(n=6)$ 


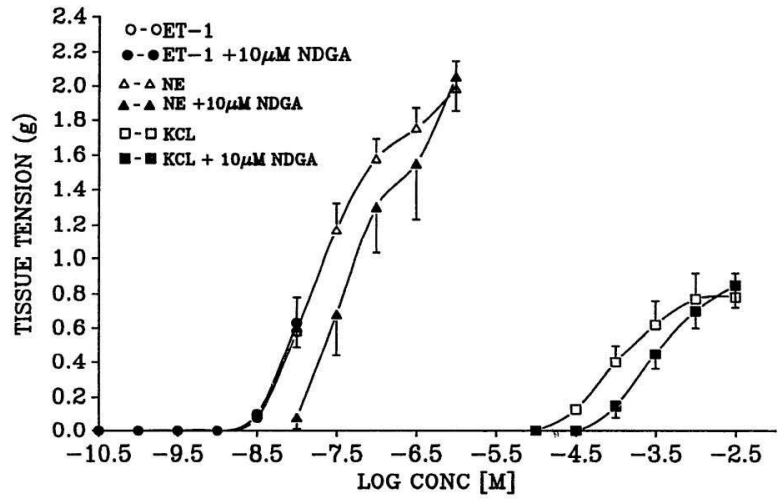




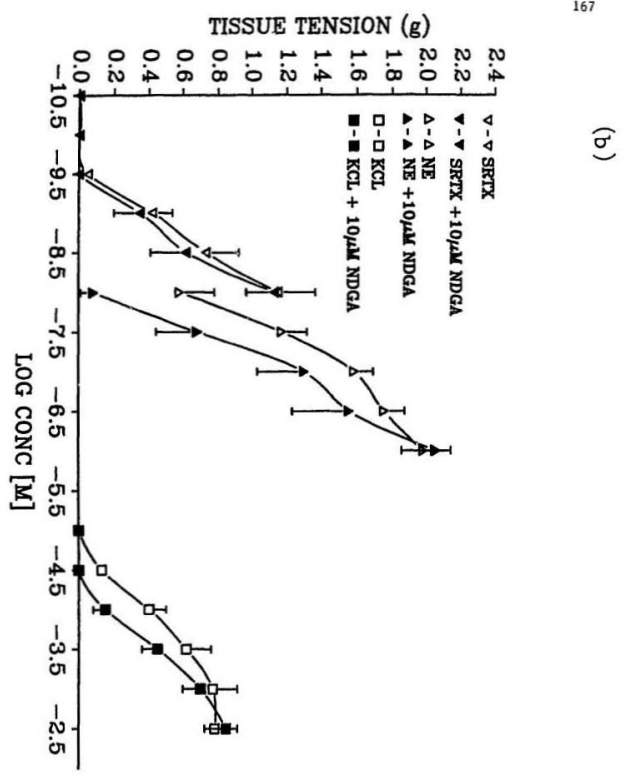


Figure 35a, b, c and d: Effect of SRTX-b and ET-1 on concentration-response curves to NE and XCL in the anococcygeus :- a) $1 \mathrm{nM}$ SRTX-b ; b) 1 nM ET-1 on NE concentration-responge curves; c) $1 \mathrm{nM}$ SRTX-b ; d) $1 \mathrm{nM}$ ET-1 on KCl concentration response curves. Control curves \pm S.E.M. are represented by open symbols, e.g. O-O and after application of ET-1 or SRTX-b by filled symbols, e.g. -O. $(n=4)$ 


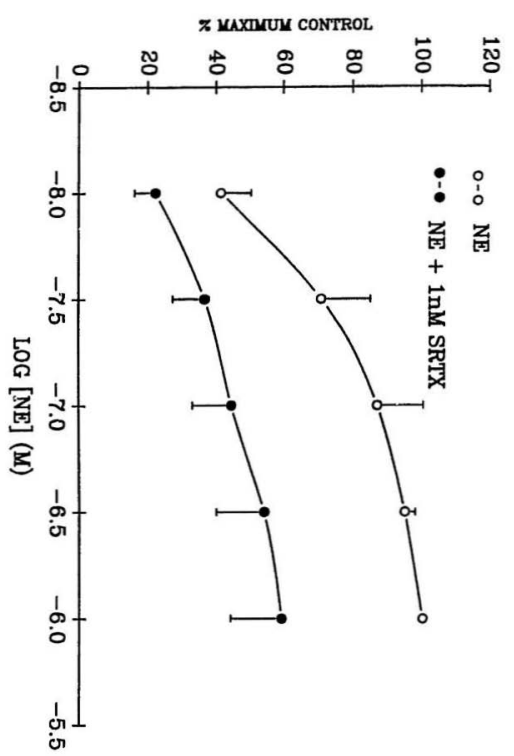

๓) 


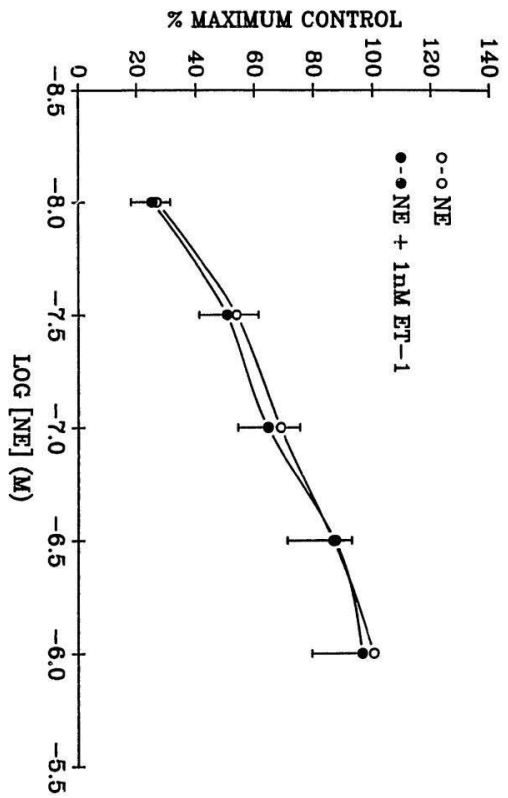


X MAXIMUY CONTROL

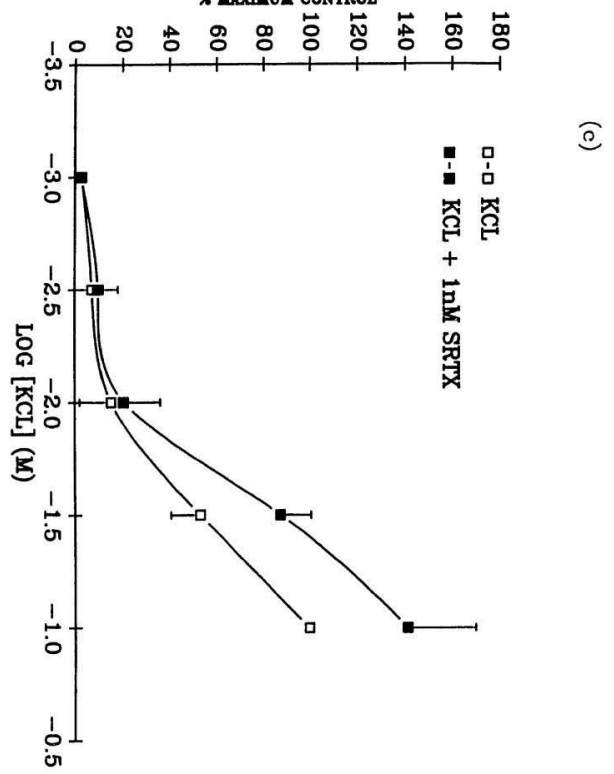




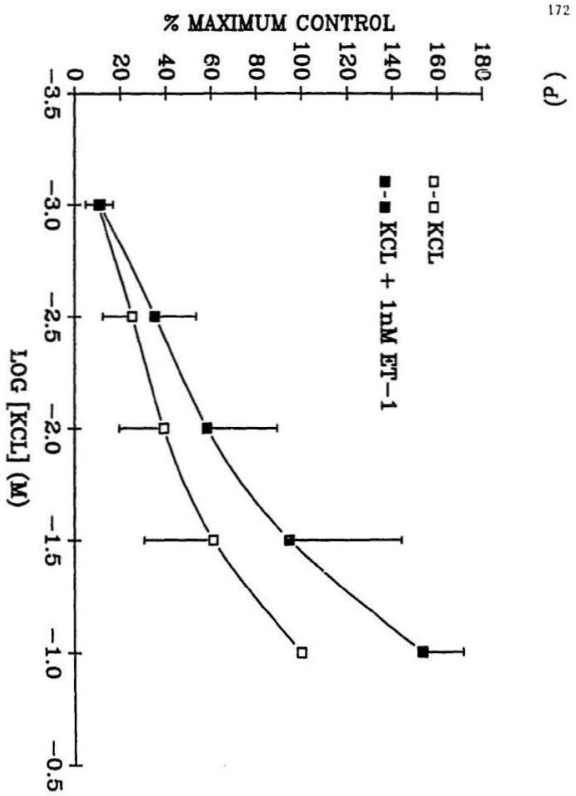


Figure 36a, b, $c$ and $d:$ Effect of SRTX-b and ET-1 on concentration-response curves to $\mathrm{WE}$ and KCL in the aorta :- a) $1 \mathrm{nM}$ SRTX-b; b) $1 \mathrm{nM} \mathrm{ET-1}$ on norepinephrine concentrationresponse curves; c) $1 \mathrm{nM} \operatorname{SRTX}-\mathrm{b}$; d) $1 \mathrm{nM} \mathrm{ET-1}$ on $\mathrm{KCl}$ concentration-response curves .

Control curves \pm S.E.M. are represented by open symbols, e.g. O-O and after application of ET-1 or SRTX-b by fil' ed symbols, e.g. - . $(n=4)$ 


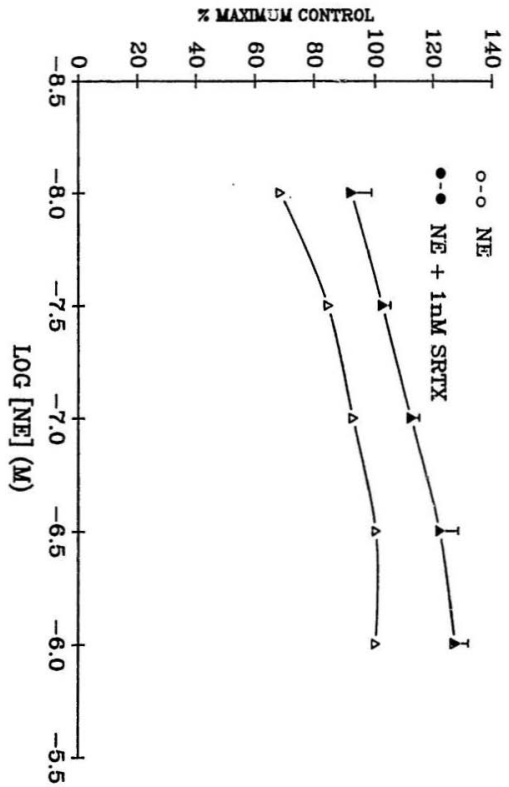

ڤ) 


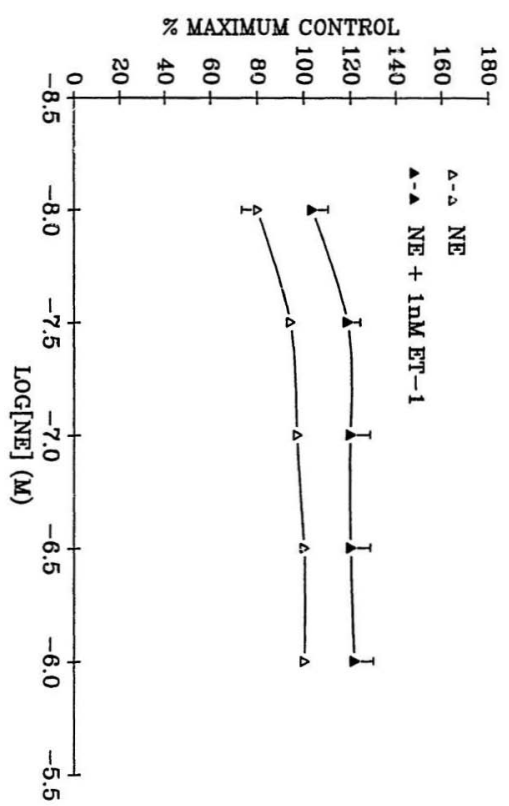

$\sigma$ 


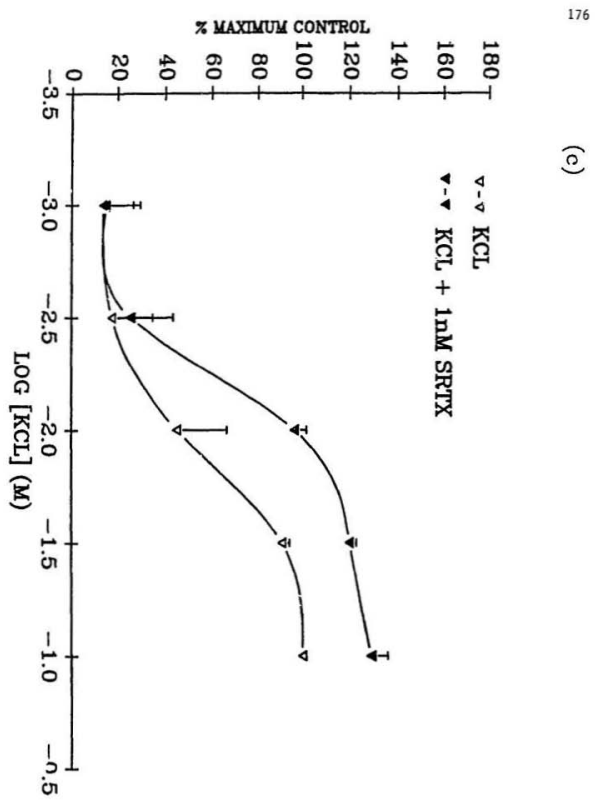




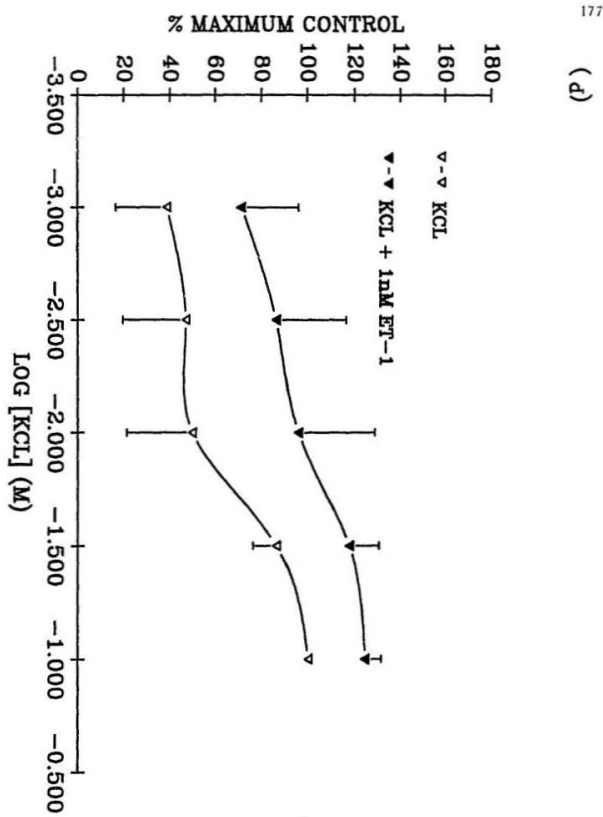




\section{Chapter 4}

\section{DIScUSSION}

\subsection{General considerations.}

This study focuged on the similarities and differences between the mode of actions of ET-1, SRTX-b and NE on vascular and non-vascular smooth muscle. The rationale for choosing to compare the responses of both vascular and nonvascular smooth muscle proparations to endothelin and sarafotoxin versus NE reflects the widespread biological effects of these peptidea on both vascular and non-vascular smooth muscle, as well as their endocrine effects on the adrenal glands, kidney and neurohypophysis. A comparison with the effects of NE was also considered logical since the effects of this amine on smooth mugcle have been extensively studied.

For such a comparison to be valid it was considered important to minimize the possible variables to a controllable number. Cognisance was taken of criticism of lsolated preparations being in an artificlal medium and perhaps reflecting a non-physiological situation. However, the choice of an 1solated preparation avoids the effects of the peptides on neuronal, endocrine and cardiovascular variables. Criteria earlier deseribed in the methods aection were used to select the experimental tissues. Consequently, the final choice of aorta and anococcygeus muscle was not only the result of pharmacological sereening but also of the published properties of thege tissues and the fact that both the control and experimental tissues were obtainable from the same animal.

Furthermore, the choice and emphasis on studying the role and sources of calcium utilized in mediating the effects of ET-1 and SRTX-b reflects a major 
interest in the role of a cation that is known to carry external signals to the cell interior with a resultant biologic response. Moreover, calcium has been implicated in altered smooth muscle reactivity in hypertension (Fitzpatrick and Szentivanyi, 1980; kwan, 1985; Dominiczak and Bohr, 1990), and the finding of high endothelin contents in bronchial exudates of asthmaties (Nomora et $21 \cdot$, 1989) suggests that the relationohip between calcium, endothelin and smooth muscle dysfunction is an important issue.

The involvement of several anplifier enzymes such as phospholipase $C$, phospholipase $A_{2}$, phospholipase $D$, adenylate cyclase and guanylate cyclase in the signal transduction process made it imperative to study the contribution or impact of the products of these enzymea in the absence of confounding variables of nerves, circulating hormones and their metabolites. It has been stated that ET-1 and SRTX-b share the same membrano recoptor and cellular mode of action ( $\mathrm{K} l \circ 0 \mathrm{~g}$ and Sokolovsky, i989) but, since there are only 668 identical amino acid sequences between ET-1 and SRTX-b (Hirata et al., 1988a; Watanabe et al., 1989; Yanagisawa and Masakl, 1989a), this conclusion may be questioned. Studies based upon diffarencea in recovery time following contractions to ET-1 versus SRTX-b with recovery in either $\mathrm{Ca}^{2+}$-containing or $\mathrm{Ca}^{2+}$-free $\mathrm{Krebs}$ suggest a role for $\mathrm{Ca}^{2+}$ in the binding and dissociation of ET-1 and SRTX-b to their receptor(3). It is speculated that these differences in apparent disgoclation constants may reflect the already noted differences in the amino acid composition of ET-1 versus SRTX-b and resultant differences in receptor blinding properties.

Recently, in an endothelin conference review, Webb (1991) noted that the IUPHAR Committee on Receptor Nomenclature and Drug Clagsification recommended that the ET-1 'selective' receptor deecribed by Arat ot al.(1990) 
and which may be the vascular smooth muscle receptor, be named the $\operatorname{ET}_{\mathrm{A}}$ receptor, and the nonselective raceptor described by Sakural, be named the $\mathrm{ET}_{\mathrm{B}}$ receptor. The endothelin receptor eloned by Arai has 427 amino acid residues (48.5 kDa) and that by sakural et al. (1990) congists of 415 amino acld residues $(46.9 \mathrm{kDa})$. They contrast remarkably with two receptors earlier fsolated in cultured rat mesangial cells (Sugiura et al., 1989) with Mw. of 58,000 and 34,000 . It is unclear whether the differences in molecular weight of the receptors is a tissue phenomenon or the result of techniques applied In the 1solation process.

\subsection{Role of extracellular calcium $\left(\mathrm{Ca}^{2+}\right)$.}

The first description of the importance of $\mathrm{Ca}^{2+}$ in the fluid bathing tisaues was made by Ringer (1883) and by implication an intracellular messenger involved in contraction. A series of observations then showed that calcium regulates not only contrantion but also many other cellular processes such as secretion of hormones (Kojima et al., 1985), neurotransmitters (Iarael et al., 1979; Knight and Baker, 1982), and glycogen metabolism in the 11ver (Cohen, 1979; Garcia-Sainz and Hernandez-Sotomayor, 1985). Some of the responses mediated by $\mathrm{Ca}^{2+}$ are brief (and of ten repetitive), but otherg are quite prolonged. Tt. a diversity of calcium messenger patterns has come to be recognized as organizational diversity of calcium messenger systems characteristic of cell type, tissue or organ (Rasmussen, 1986). Thus, there is a striking difference in the manner by which $\mathrm{Ca}^{2+}$ serves to couple stimulus to contraction in skeletal muscle as compared to amooth muscle or cardiac muscle. The ultrastructural arrangement which allows for differential gource or storage of $\mathrm{Ca}^{2+}$ has been related to phasic and tonic responses in the three types of muscles mentioned. In skeletal muscle, a distinct gource of $\mathrm{Ca}^{2+}$ 
Involved in the contraction and ralaxation is the sarcoplasmic reticulum (Ebashi et al,, 1978). Depolarization of the plssma membrane, linked to the sarcoplasmic reticulum via the $\mathrm{T}$ system (a functionai complex), induces the rolease of $\mathrm{ca}^{2+}$ leading to contraction; relaxation is achleved by repolarization and reaccumulation of $\mathrm{Ca}^{2+}$ by the sarcoplasmic ceticulum (soo review by Rasmussen, 1986). In cardiae muscle, $\mathrm{Ca}^{2+}$ cycles across both the plasma membrane and the sarcoplasmic reticulum membrane. Depolarization of the plasma-membrane leads to an influx of $\mathrm{Ca}^{2+}$ through voltage dependent channela, which results in the releage of $\mathrm{Ca}^{2+}$ from the sarcoplasmic roticulum via a calcium-1nduced calcium release process (Chapman, 1979). The resulting riae in intraceliular coleium initiates a contractile reaponse, and relaxation $1 \mathrm{~s}$ achieved by a reversal of the $\mathrm{Ca}^{2+}$ cycle.

The situation in smooth muscle is quite different as, notably in vascular smooth muscle, smooth muscle has the capability to maintain a contractile response for hours with or without depolarization (Bolton, 1979, Hashimoto et al., 1986). The sarcoplasmic reticulum of smooth muscle has been shown to be an intyacellular organelle of varlable size but in vasular smooth muscle it can be as extensive as in mammalian cardiac muscle and can accumulate $\mathrm{Ca}^{2+}$ and other divalent cations, e.g. $\mathrm{Sr}^{2+}$ (Devine ot al., 1972). It is noteworthy that Devine et al. (1972) demongtrated that there is a genera 1 correlation among different smooth muscles between the importance of extracellular $\mathrm{Ca}^{2+}$ in receptor-medlated contract lle responses and the relat lve volume of sarcoplasmic reticulum in the muscle (see review, Minneman, 1988). For example, rabbit mesenteric vein had only 2.23 sarcoplasmic reticulum and depended completely on extracellular $\mathrm{Ca}^{2+}$ for agonist-induced contractions, whereas atrips of main pulmonary artery had 5.18 sarcoplasmle reticulum and 
retalned a significant contractile response to agonist in the absence of extracellular $\mathrm{Ca}^{2+}$ (Deuine of a.., 1972). Posgibly the size of the storage pool for releasable calcium influences the relative contribution which extracellu:ar and intracellular $\mathrm{Ca}^{2+}$ make to agonigt-mediated rosponges in smooth muscle, although this does not necessarily explain how receptor activation is 1 Inked to both sourceg of calcium (MInneman review, 1988). In many muscles, the different phases of contraction have a different dependence on extracellular $\mathrm{Ca}^{2+}$ (Bevan et al., 1982). However there is no clear correlation between phasic and tonic contractions and the importance of $\mathrm{Ca}^{2+}$ Influr: (gee review, Minneman 1988). In rabblt aorta and ear artery, rapld phasic contractions caused by NE are not dependent on the presence of extracellular $\mathrm{Ca}^{2+}$ (Deth and van Breemen, 1977), whereas in rat mesenteric arteries or resistance vessels, NE-induced rapid phasic contractions aro abolished in a $\mathrm{Ca}^{2+}$-free medium (Godfraind and Miller, 1983). In rat anococcygeus muscle, slow tonic contractions to $\mathrm{NE}$ are less gensitive to inhibition by $\mathrm{Ca}^{2+}$ entry blockers than are phasio contractions (Oriowo, 1984), while the reverse holds true in rabbit aorta (Deth and van Breemen, 1977).

The results in Table 3 show the relative contribution of $\mathrm{Ca}^{2+}$ to the contractile process in rat aorta and anococcygeus mugcle for ET-1, SRTX-b and NE respectively to be $17 \pm 38,15 \pm 1.78$ and $21 \pm 2.38$ of maximal contraction in the aorta and $5 \pm .38,5 \pm .78$ and $6 \pm 1.088$ of maximal contraction in the anococcygeus muscle in normal krebs solution. A noteworthy characteristic of these contractions was that the peptides ET-1 and SRTX-b, whether in $\mathrm{Ca}^{2+}-$ free or $\mathrm{Ca}^{2+}$-containing medium, were able to initiate tonic contractions in both the aorta and anococcygeus, whereas only phasic contractions to NE were seen in both the aorta and anococcygeus when $\mathrm{Ca}^{2+}$-free Krebs was used (Figure 
8). These results are consigtent with those of wallnöfer et al. (1989) from mesenteric resistance vessels (MRV). The f.illure to tone in a $\mathrm{Ca}^{2+}-\mathrm{fres}^{2}$ medium after a transient contraction induced by NE in rabbit inferior vena cava and rabbit aorta has also been noted by Khalll and van Bremen (1990) and Mlaziro and Paiva (1990) respectively. The finding of a small suatained contraction induced by the peptides in $\mathrm{Ca}^{2+}$-free medium is consiatent with that of other reports of the actions of ET-1(Huang et al. 1990; Miasiro and Paiva, 1990). Most comparative studies of ET-1 and SRTX-b allude to their similarities of action and their responses in $\mathrm{Ca}^{2+}-f$ ree are also quite similar. However, the SUMMARY of cell signalling processes pregented in thls thesis (given overleaf) does show a variety of difference amongst the agoniata under examination. The non-maintenance of tone for $\mathrm{NE}-1$ nduced contraction in a $\mathrm{Ca}^{2+}$-free medium, in contrast to the peptides, suggests that extracellular $\mathrm{Ca}^{2+}$ has a major role to play in maintaining tone with $\mathrm{NE}$.

There is clearly a role for extracellular valcium in the contractlie response to ET-1, SRTX-b and NE as evidenced by a loss of $>80$ s of the contractile response in $\mathrm{Ca}^{2+}-$ free medium, however, this role differs for each agoniat. For example, whereas NE is capable of initiating a phasic contractile response in the absence of extracellular $\mathrm{Ca}^{2+}$, only tonic responses to $\mathrm{ET}-1$ and SRTX-b were observed (Flgure B); true phaslc response to ET-1 and SRTX-b, in both rat aorta and anococcygeus, require extracellular $\mathrm{Ca}^{2+}$. The converse was true for the initiation and maintenance of tonic responses.

The route of entry of extracellular $\mathrm{Ca}^{24}$ Into the cell has recelved considerable attention. These routea, of ten referred to as channels, can be subdivided on the basis of their selective permeablilty to particular lons, 

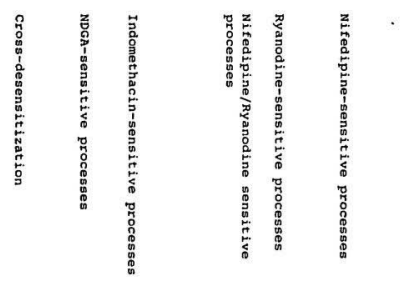

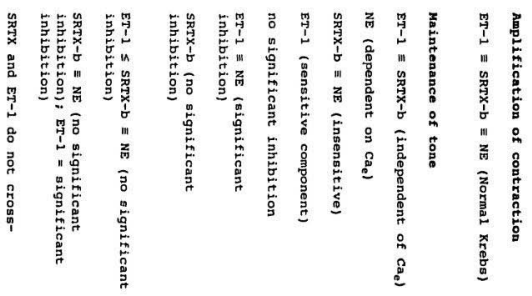

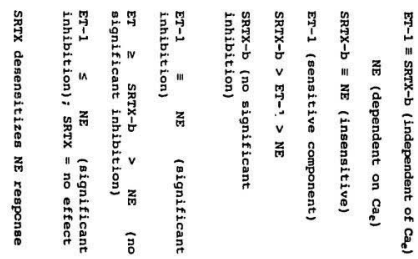

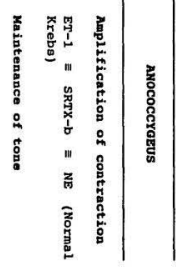


and also by the atimulus which primarily controla channel permeability (aee review by Minneman, 1988). Within each class of channels which are permeable to a particular fon and opened by a particular stimulus, there are also subclasses. So far three distinct types, namoly, "L", " $N$ " and " $T$ " type, of $\mathrm{Ca}^{2 *}$ channels have been identified in different cell types (Sturek and Hermsmeyer, 1986; Friedman et a1., 1986; Bean, 1985). These channels can be distinguighed on the basis of the strength of depolarization roquirod for channel activation, the time course of inactivation, and the sensitivity to dihydropyridine $\mathrm{Ca}^{2+}$-channel agonists and antagonists. "L-type" channele require relatively strong depolarizations for activation, inactivate al-wly, and are modulated by dihydropyridine $\mathrm{Ca}^{2+}$-channel antagonists. "T"-type" channels are activated by smaller depolarization, Inactivate rapidly, and are insensitive to dihydropyridines. "N-type" channels also require a fairly strong depolarization for activation, inactivate with an intermediate time courge, and aro also insensitive to dihydropyridines (Nowycky ot al., 1985, Fox et al., 1987). Besides the three aubelasses of voltage operated channels, suggeations of receptor-operated $\mathrm{Ca}^{2}$. channels have been mado (Bolton, 1979; visn Breemen et al., 1979). However, there has been only one report of aingle channel recording that supports the existence of receptor operated $\mathrm{Ca}^{2+}$ channels in smooth muscle (Benham and $\mathrm{Tsien}, 1987$ ). Other second messenger operated channels have been recorded in neutrophila (von Techarner et al., 1986), lymphocytes (Kuno and Gardner, 1987) and rat brain (Frager and Sarnacki, 1990).

Voltage-operated $\mathrm{Ca}^{2+}$ channels are known to be quite heterogeneous in nature, with the existence of multiple types of $\mathrm{Ca}^{2 *}$ currents in neuronal and nonneuronal cells determined using voltage elamp methods isala and 
Matteson, 1990; Bean, 1989; see review by Shearman et al., 1989). N-type channels have been reported to exist only in neuronal cells (Tsien et al., 1988; Miller, 1987) leaving " $\mathrm{L}$ " and " $T$ ' type channels whose distribution in terms of relative density in smooth muscle is not known. claims for the exiatence and non-existence of ' $T$ '-channels in emooth muscle are emerging (Ganitkevich and Isenberg, 1990; Matsuda et al., 1990) and the situation is unclear. As the L-type channel is the only type of $\mathrm{Ca}^{2+}$-channel so far identified that is gensitive to dihydropyridines (DHPs), it is also referred to as the "DHP-receptor" (see review by Shearman, 1989).

Thus far, attemptg have been made to highlight events at the level of receptor and amplifier enzymes. The effects of these enzymes on $\mathrm{Ca}^{2+}$-channel modulation, and the elaboration of other "second messengers" 11 ke IP 3 and DAG from membrane catabolism, have been compositely assesed by interference with enzymes or products of their pathways.These processes are given in the SUMMARY (Fage 184) and schematically in Figure 37.

This study has avoided receptor binding studies. Findings by other investigators (Hirata ot al,.1989; Ambar et al,,2989) have not shown any differences in binding parameters between ET-1 and SRTX-b, although euch studies have demonstrated the existence of receptor subtypes. Furthermore, the demonstration of low cross-reactivity between antibodies ralged against ET-1 and SRTX-b clearly Buggeat immune ayatem recognition and by the same token, receptor recognition (Fleminger et al. ,1989).

The failure of binding and biochemical studies to distinguish between ET-1 and SRTX-b receptors does not necessarily lead to the conclusion that these peptides interact with an identieal population of receptor.

The role of DHP-sensitive $\mathrm{Ca}^{2+}$-channels in the maintenance of contractile 
responses to ET-1, SRTX-b and NE was explored using the channel antagonigt nifedipine. In the aorta, nifedipine (10 $\mu \mathrm{M})$ significantiy reduced the maximum responses to $E T-1$, but not $N E$ and $S R T X-b$, and also reduced the sensitivity of the response to these agonlsts in the aorta (Figure $9 \mathrm{a}, \mathrm{b}$ and c). In the anococcygeus, $10 \mu \mathrm{M}$ nifedipine significantis reduced the maximal response to $\mathrm{ET}-1$, but responses to $\mathrm{NE}$ and $\mathrm{SRTX}-\mathrm{b}$ were not aignifleantly reduced (Figure $10 \mathrm{a}, \mathrm{b}$ and $\mathrm{c}$ ). However, it is noteworthy that the decrease in the maximum responses to ET-1, SRTX-b and NE was more than that observed for the aorta. The resistance of NE induced contractions in the anococcygeus to rifedipine is consistent with the finding of oriowo (1984) but the divergence in the sensitivity of responses to ET-1 in aorta and SRTX-b in anococcygeus were surprising for peptldes that are sald to act on the same receptor and have the same mode of action (Kloog and sokolovsky, 1989). Desplte the clear dependence on extracellular $\mathrm{Ca}^{2+}$, the inablifty of nifedipine treatment alone to completely inhibit the responses in both preparations, indicates that cellular mechanisms other than voltage-operated calcium channels muat also play a significant role in the contractle processes activated by the two peptides and NE. It should also be noted that the concentration of nifedipine, to $\mu \mathrm{M}$, that was uged in these otudieg 10 high and the inhibitory effectg noted agalngt ET-1 may reflect oome nonspecific actions of this substance that are not yet documented. Recently, Inoue et al.(1990) demonstrated that $\mathrm{ET}-1$ augments unftary Ca ${ }^{2 *}$-channel currents in the guinea pig portal vein and they were able to characterize two types of unftary $\mathrm{Ba}^{2+}$ currents whth conductances of 22 ps and $12 \mathrm{ps}$. Nifedipine was said to inhibit both types of unitary channel current, although the sensitivity of $22 \mathrm{ps} \mathrm{Ca}^{2+}$ channel was 20-fold higher than the 12 
ps $\mathrm{Ca}^{2+}$-channel. Although Inoue et al. (1990) did not specifically exarnine the effects of $w$-conotoxin on the 12 ps current generated by ET-1, other gtudies (Lawson and Chatelain, 1989; Topouzis et al., 1989) guggest that the 12 ps current is an N-type channel. Thus, based upon slope conductance analysis, the two types of current that ET-1 activates in the guinea pig portal vein could represent those produced by " $L "$ and " $N "-t y p e \mathrm{Ca}^{2+}$-channels. Rosink of al. (1990) have demonstrated the internalization of ET-1 receptors by cultured human vascular smooth muscle cells and have therefore suggested that this process may be relevant to the characteristically pergistent contractile effects of this peptide on the vasculature. In view of its persigtont contractile effects, it is likely that the sRTX-b receptor undergoes a similar process, however, this has not yet been demonstrated.

Ino et al. (1988) have demonstrated the existence of two classes of caleiun. atores in guinea pig portal vein, pulmonary artery and taenia coli one with both " $\mathrm{Ca}^{2+}-$ induced $\mathrm{Ca}^{2+}$ release" (CICR) and "IP3-induced $\mathrm{Ca}^{2+}$ release" (IICR) mechanisms ( $\underline{S} a$ ) and the other only with the IICR mechanisma $(\underline{B})$. These authors demonstrated that after ryanodine treatment, the $\mathrm{Ca}^{2+}$ store $(\underline{S} \alpha)$ lost its enpacity to hold saleium and went further to suggest thit the $\mathrm{Ca}^{2+}$ released from $\underline{\mathrm{S}} \alpha$ produces the initial phase of contracture. By far the nost interesting question raised by Iino et al. (1988) is: "If the Becond messenger for the agonist is Indeed $\mathrm{IP}_{3}$ as has been suggested in many other cells (Berridge and Irvine, 1984), then why do agonists not release $\mathrm{Ca}^{2+}$ from $\underline{s} \beta$ in the absence of extracellular $\mathrm{Ca}^{2+}$ ?" rino et al. (1988) suggested a number of possibilities - one is that following agonist action the releaged $I P_{3}$ may not reach the $\underline{S}^{\beta}$ site, alternatively $I P_{3}$ may not be used as the second massenger or finally, that IICR from Sß requires extracellular $\mathrm{Ca}^{2+}$. Iino ot 
a1. (1988) argued that aince the IICR has been shown to be dependent on a $\mathrm{pCa}^{2+}\left(-\log \left[\mathrm{Ca}^{2+}\right]\right)$ of approximately 7 (Iino, 1987), it is possible that IP releases $\mathrm{Ca}^{2+}$ from $\underline{S B}$ only when there is sufficient $\mathrm{Ca}^{2+}$ influx to keep the $\mathrm{Ca}^{2 *}$ concentration in the vicinity of the otore higher than a certain critical level. They finally submitted that there could certainly be other possibilities which needed further study and clarification. The suggestion by Iino et al. (1988) that ryanodine geems to hold the $\mathrm{Ca}^{2+}$ channels of the S $\alpha$ stores $f$ ixed in an open configuration has been supported by the finding of Hisayama and Takayanag1 (1988). In the presence of ryanodine, even if stored $\mathrm{Ca}^{2+}$ was depleted by caffeine, the rate of rige of the extracellular $\mathrm{Ca}^{2+}$ induced contraction remalned at a higher level.

My data with anococcygeus muscle are consistent with the finding of Hisayama and Takayanagi (1988) concerning the effects of ryanodine, but the conclusion from my data is that the $\mathrm{Ca}^{2+}$ mobilizing mechanisma, and ability to sustain them, are $11 k e l y$ to be agonist dependent. In this regard, the Rasmussen model for $\mathrm{Ca}^{2+}$ cyeling across the membrane and the association of protein kinase $c$ with the plasma membrane in the presence of dlacylglycerol oustaining the cellular response may only be valid in the presence of extracellular $\mathrm{Ca}^{2+}$. The inability of $\mathrm{NE}$ to maintain a sustained contraction In the absence of extraceliular $\mathrm{Ca}^{2+}$ questions this model, in that $a-$ adrenoceptor activation is thought to Involve the production of diacylglycerol and inositol trisphosphate(see review by Minneman, 1988). Furthermore, the abillty of ET-1 and SRTX-b to maintain sustained tone In the absence of extracellular $\mathrm{Ca}^{2+}$ indicates that there is more to sustained cellular response than membrane association of diacylglycerol and $\mathrm{Ca}^{2+}$ mobilization by IP3. A crucial question is if $N E$, as for ET-1 and SRTX-b, 
produces IP $P_{3}$ and DAG on receptor activation, why is the response to NE phasicIike and those to ET-1 and SRTX-b tonic-like in a Ca ${ }^{2+}-f$ ree Krebs? No definite answer can be provided at this time.

Further experiments were conducted to compare and evaluate the role of oxtracelilular veraug intracellular $\mathrm{Ca}^{2+}$ in the soitractile response to $\mathrm{ET}-1$, SRTX-b and NE. In these experiments, :ontrol cumulative $\mathrm{Ca}^{2+}$ concentration response curves were constructed in the presence of an appropriate agoniat, tissues were then washed and incubated in $10 \mathrm{pM}$ ryanodine for one hour following which the $\mathrm{Ca}^{2+}$ concentration response curves were repeated. In this study, the same concentrations of the agoniats (1.0. $10 \mathrm{nM} \mathrm{ET-1,10} \mathrm{nM} \mathrm{SRTX-b}$ and $1 \mu \mathrm{M} \mathrm{NE}$ ) were used as in other phases of this project. After washing and recovery to baseline, the tissues were again subjected to ryanodine treatment in the uresence of $10 \mu \mathrm{M}$ nifedipine in light-proof chambers and $\mathrm{Ca}^{2+}$ concentration responge surves were constructed in the presence of the appropriate agonist. Responses to ET-1 in the anococcygeus muscles were Bignificantly enhanced by ryanodine treatment alone (Figures $15 a, b$ and $c$ ). Treatment with nifedipine significantly reduced the responses to $\mathrm{ET}-1$ and NE but oignificantly leod so for SRTX-b (table 4). It is apparent that the extracellular $\mathrm{Ca}^{2+}$ requirements for ET-1 and NE induced contractions partly utilize nifedipine-sensitive voltage operated channels. There is, however, a component of each contraction which is nifedipine-insensitive. The responge to SRTX-b following depletion of the intracellular ryanodinesensitive store and nifedpine blockade was not significantly reduced, guggesting that $\mathrm{Ca}^{2+}$ entry may depend upon non-selective cation channels (Owen et al., 1986; Patridge and Swandulla, 1988; Oortigiesen et al., 1990). Additional experiments to explore the preliminary finding that ryanodine 
and NE depleted the same store(s) of intracellular calcium were conducted. Figure 17 a demonstrates that repeated stimulation with NE in anococeygeus could only deplete the tissues of calcium to a certain basal level beyond which further depletion seemed impossible, even for an extended stimulation of 2-3 hourd. Figure $18 a, b$ and $c$ demonetrate caleium responee curves of the three agonists under examination following depletion of the $\mathrm{NE}$ gensitive $\mathrm{Ca}^{2+}$ atores with repeated NE exposure. When compared to deplation of cellular $\mathrm{Ca}^{2+}$ stores with ryanodine (Figures $15 \mathrm{a}, \mathrm{b}$ and $\mathrm{c}$ ), the reoponses were aimilar in the anococcygeus except that nifedipine did not significantly reduce the NE response as was the case following ryanodine treatment. These data confirm the postulate of Inno et al. (1988) that $\underline{\text { s }}$ stores are sensitive to ryanodine and $\mathrm{IP}_{3}$ generated by agonist. The only discrepancy was the insignificant: reduction of $\mathrm{NE}$ response by nifediplne following NE induced-depletion of cellular $\mathrm{Ca}^{2+}$ stores. Furthermore, the data indicate that ryanodine, unlike NE, holds intracellular $\mathrm{Ca}^{2+}$-channels in an open conflguration such that the Intracellular stores loge their capacity to reaccumulate $\mathrm{Ca}^{2+}$ following stimulation, whereas NE depletes the cellular stores of $\mathrm{Ca}^{2+}$ but leaves them With the ability to reaccumulate and maintain a functional capacity. The availability of $\mathrm{Ca}^{2+}$ stores that are sensitive only to $\mathrm{IP}_{3}$ explains the capacity of NE to evoke a contraction after treatment with ryanodine. An Interest ing development L $_{\text {s }}$ the Lolation of the $\mathrm{IP}_{3}$ receptor (Chadwick et a1., $1990)$ and the inability to lsolate $\mathrm{Ca}^{2+}$-indueed $\mathrm{Ca}^{2+}$ release channela from the sarcoplasmic reticulum of smooth muscle. It was concluded that, although there is an $I P_{3}$ receptor in amooth muscle, shere may not be a diatinct ryanodine receptor (Chadwlck et a1., 1990). It is most probable that this store varies from tissue to tissue since Patel and Triggle (1986) were able 
to deplete the rat tall artery of $\mathrm{Ca}^{2+}$ by repeated exposure to $\mathrm{NE}$.

Further attempts to addsess the question of which intraceliular calcium pools were sensitive to ryanodine andfor NE involved experiments in which tisgues were repeatedly stimulated with NE in a $\mathrm{Ca}^{2+}-\mathrm{free}$ Krebs and then incubated in ryanodine for one hour. The results from anococcygeus (Figures 20a, b and c) maintained a pattern similar to those with ryanodine alone which were earlier described (Figures $15 a, b$ and $c$ ).

The possibility that the effectiveness of ryanodine could be enhanced by the simultaneous presence of an agonist which effectively holds the ryanodine-sensitive release channel in an open state, thus enhancing $\mathrm{Ca}^{2+}$ depletion, was explored. In order to address this possibility, experiments were derigned in which ryanodine alone, ryanodine and caffeine, and ryanodine and agonist, respectively, were uged to deplete the tissue of cellular $\mathrm{Ca}^{2+}$. In the anococcygeus (Figures $22 \mathrm{a}, \mathrm{b}$ and $\mathrm{c}$ ) $\mathrm{Ca}^{2+}$ concentration- response curves In the presence of $10 \mathrm{nM} S R T X-b$ and $10 \mathrm{nM}$ SRTX-b plus ryanodine showed no aignifleant differences when evaluated by ANOVA. The data presented are consigtent with those of Iino et al. (1988) who concluded that ryanodine acts on the calcium induced calcium release (CICR) channelo only when they are spen, and that ryanodine does not have any appreciable effect on the IPincluced calcium release (IICR) channels even if the drug is applied when these channels are open. From my data concerning interactions between caffeire and ryanodine I conclude that caffeine and ryanodine likely act on the same calcium pool(g). Support for this hypothesis is provided by the fact that the effects of ryanodine with and without caffeine were not gignificantly different from each other. Figure $23 \mathrm{a}, \mathrm{b}$ and $c$ illustrate the responses obtained in anococcygeus with the use of ET-1. Evaluation of the 
three Independent varlables by ANOVA showed that the observed difference was not aignificant thus confirming earlier findings with skTX-b concerning depletable $\mathrm{Ca}^{2+}$ pools.

Further elueidation of the routes of entry of extracellular calcium had become necessary as blockade with nifedipine had boen shown to be only partially efiective and then only when uged at a high concentration. To explore the roles of $\mathrm{Ca}^{2+}$ entry via dihydropyridine modulated $\mathrm{Ca}^{2+}$-channela in contractions induced by ET-1, SRTX-b and NE a known L-type calcium channel opener Bay K 8644 was used with depolarizing (15 mM K*) Krebs buffer. Figure $26 \mathrm{a}, \mathrm{b}$ and $=$ show the responses in anococcygeus to Bay $\mathrm{K} 8644$ without and with $1 \mathrm{nM} \mathrm{ET-1}$ and $S \mathrm{RTX}-\mathrm{b}$ and $100 \mathrm{nM} \mathrm{NE}$ (subcontractile concentratione). Contractile response to the three agonists was noted but since the response of the anococcygeus to Bay K 8644 (Figure 27) did not denongtrate strict concentration dependence, these differences were not statiscally evaluated for significance. This suggest the involvement of non-gelective cation channels and perhaps, "W" and " $"{ }^{\prime \prime}-t y p e$ channels in the contractile process of the smooth muscle an proposed by several authors (D'Orleans-Juste et al., 1989; Van Renterghem et al., 1989; Patridge and Swandulla, 1988; Inouo et al., 1990).

In further experiments conducted to compare and evaluate the role of extracellular versus intracellular $\mathrm{Ca}^{2+}$ in the contractile response to ET-1, SRTX-b and NE in the aorta (Figures 16a, b and $c$ ), a combination of ryanodine and nifedipine produced a marked and signiflcant Inhlbition (ANOVA) of the contractile response to $\mathrm{ET}-1$ and NE, but not SRTX-b (see also Table 4). This suggests that an intracellular source of $\mathrm{Ca}^{2+}$, which is maintained by extracellular $\mathrm{Ca}^{2+}$ entering via a nifedipine-sensitive route plays a 
significant role in determining the contractile response to ET-1 whereas nifedipine-ingensitive routes are utllized by and sRTX-b.

Experiments to expand on the preliminary finding that ryanodine and $\mathrm{NE}$ depleted the same stores of intracellular calcium in the aorta (Bigure 17b) denonstrate that repeated atimulation with NE in a $\mathrm{Ca}^{2+}$-free Kreba could only deplete the tissues of calcium to a certain basal level beyond which further depletion seemed impossible. Figures $19 a, b$ and $c$ demonstrate responges to BT-1, SRTX-b and NE from the aorta following depletion of NE-sensitive $\mathrm{Ca}^{2+}$ gtores with repeated NE exposures. When compared to depletion of cellular $\mathrm{Ca}^{2+}$ stores with ryanodine, it can be seen that the results were similar (Figure 16a, b and c). Sequential depletion in aorta of $\mathrm{NE}-$ sensitive $\mathrm{Ca}^{2+}$ stores with repeated NE exposures followed by incubation in ryanodine (Figures 21a, b and c) were not different from Figures $19 a, b$ and $c$ or Figure $16 a, b$ and c thus confirming our earlier speculation that ryanodine and NE acted on the same depletable $\mathrm{Ca}^{2+}$ pool.

In a parallel atudy with the aorta, designed to determine whether ryanodine was more effective in the presence of an agonist, ryanodine alone, ryanodine and caffeine, and ryanodine plus either the agonist SRTX-b or ET-1 were compared (Figures $24 \mathrm{a}-\mathrm{C}$ and $25 \mathrm{a}-\mathrm{c}$ respectively). No significant differences were observed (ANOVA). Nifedipine, even at $10 \mu \mathrm{M}$, proved to be only partlally effective at Inhiblting the responses to SRTX-b, ET-1 and NE in the aorta and thus, additional experiments were designed to elueidate the role and routes of extracellular $\mathrm{Ca}^{2+}$ utillzation. Figures $28 \mathrm{a}, \mathrm{b}$ and $\mathrm{c}$ demonatrate enhancement of reaponses to ET-1, SRTX-b and NE over the control responses induced by $10 \mu \mathrm{M}$ Bay $\mathrm{K} 8644$ in a depolarizing (15 $\mathrm{mM} \mathrm{K} \mathrm{K}^{+}$) Krebs alone. In contrast to anococcygeus, the responges of aorta to Bay $\mathrm{K} 8644$ 
demonstrated a strict concentration dependence (Figure $27 \mathrm{~b}$ ) . No explanation for the "flapping" responses of anococcygeus to Bay K 8644 when contrasted with the sustained tone and concentration-dependent responses exhiblted by the aorta to Bay K 86344 (Figure $27 \mathrm{a}$ and b) can be offered, although electrophyeiological studies may provide an insight.

\section{4 kole of erachidonic acid metabolites.}

There is a direct association between phosphatidylinositol turnover, diacylglycerol production, and arachidonic acid release (bee roview by Rasmussen, 1986). Arachidonic acid could be generated by one of three mechanlsms: from phosphatidylinositol 4,5-bisphosphate (PIP $)$ to diacylglycerol with further metaboliam to phosphatidic acid and arachidonic acid or from phosphatidylcholine to lysophosphatidy 1 choline and arachidonic acid. The metabolism of phosphatidic acid to arachidonic acid from these pathways is catalyzed by phosphollpase $A_{2}$ (see review by Exton, 1988). An alternate pathway is the hydrolysig of phosphatidyleholine by phospholipaso $C$ and $D$ to arachidonic acid (Irving and Exton, 1987). The view that agonist increases diacylglycerol levels solely via the stimulation of phosphatidylinositol blsphosphate $\left(\right.$ PIP $\left._{2}\right)$ breakdown and resultant. DAG leading to phosphatidic acid is not atrictly supported by experimental data. Emergent blochemical data (Irving and Exton, 1987; Bocckino ot a1., 1985) have revealed that fatty acid composition of DAC and/or PA produced greatly exceeds the decreage in mass of inositol phosphollpids. Thus, agonlatg may induce the breakdown of another phospholipid, phosphatidylcholine, and support for this hypothesis is provided by the agonist induced increases in phosphocholine and choline seen in hepatocytes, JT3 fibroblasts and anooth 
mugcle cello (see review by Exton, 1988).

There seems to be a provalent notion (see Rasmugaen, 1986) that once produced, arachidonic acid ia rapidly metabalized largely via the cyclooxygenase pathway to endoperoxides, prostaglandins and thromboxane $A_{2}$ with negligible contribution of the lipoxygenase pathway. Data from recent gtudies with endothelin (Rapoport et al., 1990) seem to agree with thls notion. However, it is well establighed that some lipoxgenase products (Vanhoutte et al., 1985) do affect smooth muscle function, and a role for 11 poxygenase metabolites in mediating the effects of ET-1 has been described by Resink et al. (1989). Furthermore, the work of Reynolds et al. (1989) has demonstrated that phorbol ester treatment dissociated endothelin-stimulated phosphoinositide hydrolysis and arachidonic acid release in vascular smooth muscle cells. This later study suggests parallel or synergistic mechanisms for Initiating the contraction of smooth musele.

In view of the possible role of arachidonic acid metabolites in agonist Induced contraction, the effects of ET-1, SRTX-b and NE were explored by constructing calcium concentration response curves in the presence of these agonists and in the absence or presence of the cyclooxygenase inhibitor, indomethacin $(10 \mu \mathrm{M})$, (Figure 29a, b and $\mathrm{c}$ for anococcygeus). The responseg to the three agonists in presence of indomethacin were not significantly different frcm each other as analysed by ANOVA. Thus, at least in the anococcygeus, products of cyclooxygenase are of negligible consequence in the contractile process (see Table 4). The results were gimilar for the aorta (Figures 30a, b and $c$; Table 4). These findings are in contrast to Rapoport et a1. (1990) who noted a significant inhibition by indomothacin of ET-1 Induced responses in the aorta. Further examination of the effects of the 
three agonists in the anococcygeus in the abaence and presence of $10 \mu \mathrm{M}$ nordihydroguaiaretic acid (NDGA), a lipoxygenase Inhibitor, revealed that responves to ET-1 and NE were significantly reduced when comparad to controlo by "t"-test analysis (Figure $31 a-c$, and Table 4 ). In the aorta (Figure $32 a, b$ and e), responses to SRTX and NE when compared to controls were not Bignificantly reduced by NDGA, whereas that to ET-1 was gignificantly reduced when examined by the "t"-test respectively. The inability of (ANOVA) to detect a significant difference may reflect the low number of experimental replications. The results with ET-1 were consistent with the findings of Resink et al. (1989) who observed almost complete inhlbition of ${ }^{3} \mathrm{H}$ )arachidonic acld release by NDGA, suggesting that such extracellular labelled materials represented eicosanoid metabolites derived from lipoxygenase activity. Resink ot al. (1989) also found that endothelin-induced arachidonic acid release was relatively insensitive to both indonethacin and meclofenamate (cyclooxygenase Inhibitor), thus confirming our finding of lack of effect of indomethacin on responses to ET-1, SRTX-b and NE. The findinge of Resink et al. (1989) also suggest that it is phosphol ipase $A_{2}$ that mediates the generation of the lipoxygenase product following endothelin stimulation as they report that neomycin, a putatlve phospholipage C Inhibitor (s1luka and Insel, 1987), did not inhibit arachidonic acid releage. Resink ot al. (1989) concluded that the lack of inhibition by neomycin indloates that activation of phosphollpase $A_{2}$ by endothelin may occur through a pathway that Is Independently parallel with, rather than secondarily gequential to, the phospholipase $C$ pathway. Such independent pathways have been proposed for $\alpha_{1}-$ adrenerglc receptors (SIlvka and Insel, 1988; Burch ot al,, 1986). The data from my experiments do not support thls hypothesis, at least in the aorta, 
alnce SRTX-b was not algnificantly inhibited by NDGA. However, in the anococcygeus, the NE response was significantly inhibited by NDGA. This further points to the diversity of pathways utilized by the different agonista in different tiscuea. Reynolds ot al. (1989) have shown the doseresponse relationship of endothelin to $\left.i^{3} H\right]$-inositol phosphate formation and $\left({ }^{3} \mathrm{H}\right]$-arachidonic acid release in rabbit renal artery vascular smooth musclo cella and have alluded to the fact that since the EC5o values for both responses were very simllar, 0.2-0.4 nM, both respones were, mogt likely, mediated by a single population of endothelin receptors. Reynolds ot al. (1989) noted that, in the FRTL5 thyroid colls, pertussis toxin completely inhibited $a_{1}$-adrenergic receptor medioted $P L A_{2}$ activation but did not affect $a_{1}$-adrenergic receptor-mediated phosphollpase C activation (Burch et al., 1986). These data indicate that $a_{1}$-adrenergic receptore of these celle were coupled to PLC and PLA 2 by different G proteins. Reynolds et al. (1989) concluded that the coupling of $\alpha_{1}$-adrenergic receptors to phospholipase c (PLC) and phospholipase $A_{2}$ (PLA ) activation occurred in parallel and was independently regulated in those cells.

The question of non-specific actions of NDGA (Rimele and Vanhoutte, 1983) was addresued by dosigning experiments which compared the inhibition of contractile response produced by NDGA on agonist cumulative concentration response curves, e.g. ET-1, NE compared to inhibition by uDGA of earcium ,ncentration response curve in the presence of $50 \mathrm{mM} \mathrm{K} \mathrm{K}^{+}$. Figure $33 \mathrm{a}$ and $\mathrm{b}$ showed that in the anococcygeus preparation, where significant inhibition of the maximal response to NE by NDGA was achieved, no significant inhibition by NDCA of $\mathrm{x}^{+}$induced contrastions were noted. Figures $34 a$ and b show that in the aorta, no signifleant reduction of contractlie response to elther NE or 
$\mathrm{K}^{*}$ by NDGA was achieved. A comparison of Eigures $33 \mathrm{a}$ and $\mathrm{b}$ to figures $34 \mathrm{a}$ and b leaves some possibility for equivocation and as such the specificity of NDGA may be questionable. Nonetheless, the more recent work by Scriabine, Pan and Vanhoutte (1990) has shown that the NDGA action was specific for 11poxygenase.

\subsection{Agonist cross-desensitization.}

In the course of tissue screening, it was noted that ET-1, SRTX-b or NE, when cumulatively adminiatered to reach bath concentrations of $10^{-7} \mathrm{M}$ or 0.1 $\mu M$ for ET-1 or SRTX-b, and $10 \mu \mathrm{M}$ for NE, often resulted in desensitization to subsequent stimulation. It was reasoned that this might be desensitization or tissue toxicity and since the experimental protocol demanded repeated administration of a particular agonist, this question had to be addresact. As earlier pointed out in the Materials and Methods section, it was observed that if the concentration of $10 \mathrm{nM}$ for $\mathrm{BT}-1$ and SRTX-b or $1 \mu \mathrm{M}$ for NE was not exceeded, desensitization on subsequent stimulation was not apparent and reproducible concentration response curves to ET-1, SRTX-b and NE could be obtained for up to 4 hours (Table 1). In the otudy by Miasiro and Paiva (1990). ET-1 pretreatment in rabbit aortic rings and cultured rat aorta smooth muscle cella did not affect responses to angiotensin II and NE, thua demonstrating homologous degengitization to ET-1. However, the concentration used was $100 \mathrm{nM}(0.1 \mu \mathrm{M})$ which, as demonatrated in this study, Ls suffielent to induce myogenic activity in anococcygeus or subsequent non-response in the aorta. At the concentrations used in my study, which were approximately $\mathrm{EC}_{50}$ values for these agonlets, desensitization was not observed and thus our findings are not conslstent with those of Miaslro and Palva (1990). A good discourse of the phenomena of desonsitization (Triggle, 1980) does not seem 
to relate degensitization to dose or concentration, which the author dofines as diminished response during, or subsequent to, the initial action of a drug (variously described as tachyphylaxis, tolerance, rofxactorinese or subsensitivityl. Recent developments in this area have clearly indicated that conditions which decrease or increase agonist-receptor interaction, either chronically or acutely, result in opposing alteratione in effector gensitivity (Triggle, 1980). Given the agonist-receptor internalization of ET-1 as noted by Resink et al. (1990), it could be argued that internaliation of ligand-receptor complex leads to loss of receptor, thereby providing the basis for desensitization. However, Auguet et al. (1990) had demongtrated that even at concentrations as low as $30 \mathrm{nM}, \mathrm{EI}-1$ but not sRIX-b induces crosg desengitization of rat aorta to SRTX-b or ET-1, respectively. In a second set of experiments, Auguet ot al. (1990) using $0.1 \mu \mathrm{M}$ of ET-1 or SRTX$b$ demonstrated that pretreatment with SRTX-b did not affect subsequent responges to ET-1 or SRTX-b whereas pretreatment with BT-1 significantly reduced responses to ET-1 and SRTX-b. Auguet et a1. (1990) concluded that ET-1 and SRTX-b may activate a common receptor since BT-1 induces degengltization to both ET-1 and SRTX-b and went on to postulate that SRTX-b, unlike ET-1 (Hirata et al., 1988a), may be more readily dissociable from its binding gite and hence does not normally induce desensitization. Furthermore, Auguet et al. (1990) suggest that the long lasting effect of the peptides of the ET/SRTX family is more likely to be due to their post-receptor events rather than to the nature of binding of the drug to the receptor (irreversible or not), gince the rate of washout was the gamo with the contraction induced by ET-1 and that induced by SRTX-b. MY data, as determined by 1088 of myogenlc activity in anococcygeus (Figure 6 and Table 
3). show differing dissociation characteristies of ET-1 and SRTX-b. The argument that this activity may be a post-receptor event may be conceded on the basis of the work 'I Van Renterghem et al. (1989) and sakata ot al. (1989) who related ET-1-induced "spiking" activity to $\mathrm{Ca}^{2+}$ - activated $\mathrm{x}^{*}$ channels and cytorolic $\mathrm{Ca}^{2+}$ apikes to mechanlcal regponas of tonus respectively.

However, my data (Figure $35 \mathrm{a}$ and $b$ ) demonstrate the phenomenon of crosedesensitization between SRTX-b and NE in rat anococcygeus and the absence of cross-desensitization between ET-1 and NE. This contrasts markedly with the data presented in Flgure $35 \mathrm{c}$ and $d$ whlch were designed as controls for the NE response by vubstituting cumulative concentration response curves of NE with $\mathrm{KCl}$. In this subset, enhancement of the maximal response to $\mathrm{KCL}$ was noted With both ET-1 and SRTX-b. Statiatical eveluation of responges by ANOVA showed signiflcant differences for the effects of SRTX-b on the NE response and the SRTX-b effect on the KCl concentration response curves. This contrasts with the $\mathrm{ET}-1$ effect on $\mathrm{NE}$ and $\mathrm{KCl}$ concentration response curves Where comparisons in the anococeygeus were not algnificant as assessed by ANOVA. In the aorta (Figures $36 \mathrm{a}, \mathrm{b}, \mathrm{c}$ and $d$ ), there was no desensitization, as assesed by ANOVA analysis to NE or KCl after pretreatment with elther ET-1 or SRTX-b.

\section{Conclusions}

The most obvious conclusion that can be reached from the present otudy 1s that ET-1 and $s \mathrm{RTX}-\mathrm{b}$ interact with a heterogeneous population of receptors. If ET-1 and SRTX-b do interact with a homogeneous receptor population, then signal transduction pathways are differentially 
activated(see also Galron et a1.1990). However, my data does suggest that the affinity of ET-1 and SRTX-b binding to their receptor(g) in the anococcygeus is increased in the presence of extracellular $\mathrm{Ca}^{2 *}$ and this is reflected by the time interval needed for disappearance of induced myogenic activity in the anococcygeus muscle in $\mathrm{Ca}^{2+}$-containing and $\mathrm{Ca}^{2+}$-free Krebs buffer. $\mathrm{A}$ comparison of this interval in either Krebs golution ghowe that SRTX-b dissoclates faster from its receptor than does ET-1. In contrast, the effects of $N E$ can be terminated in less than 2 minutes. ET- 1 has been shown to be internalized by endocytosis along with its receptor (Resink et al., 1990) and this may explain the basis of the persistent contractile activity of tho peptides.

In some respecta, the resistance of the effectg of sRTX-b to inhibition by nifedipine in the anococcygeus bears atrong similarities to the reaistance of NE to nifedipine. Moreover, the demonstration of cross-desensitization of NE effects by SRTX-b in the anococcygeus suggest that these agonists may Ghare a common post-receptor mechanism coupled via a common G-protein.The significant reduction in the aorta of $\mathrm{ET}-1$, but not NE and SRTX-b, responsen by nifedipine points to the divergent utilization of $\mathrm{Ca}^{2+}$ channels by the two peptides in different tisgues. The validity of this suggestion is not diminished by the finding of no signiflcant differences (ANovA) between the three agonist following nifedipine treatment tecause other protocolg

(nifedipine and ryanodine) have demonstrated significant differences between the peptides (ANOVA), Table 4. The electrophysiologie characteristics of small depolarizations $(-7 \mathrm{mV})$ for $\mathrm{ET}-1$ in contrast to $-20 \mathrm{mV}$ for NB (Wallnöfer et al, 1989), and the suggestion of the role of "N"-type channela (Inoue et a1., 1990) for ET-1 along with the sensitivity of response to 
dihydropyridines, suggest that ET-1 may be opening "L" and "N"-type ealcium channels whereas SRTX-b may be opening " $L$ " and " $T$ "-type calclum channels depending on the preponderance of channels in the tissues. "N"-type channels, however, have not previously been associated in smooth muscle.

The inability, after ryanodine treatment, of nifedipine to further Inhibit SRTX-b respongeg in the aorta is in contrast to tho near complete inhibition of ET-1, after ryanodine treatment, thus lending additional support to the divergent use of calcium pools by the three agonists. This leads to the conclusion that the processes affecting $\mathrm{Ca}^{2+}$ mobilization are an intrinsic property of an agonist and the avallability of sensitive $\mathrm{ca}^{2+}$ stores in a particular tiseue determines the effectiveners of the agonit.

Since ET-1, SRTX-b and NE have been shown to produce DAG and $\mathrm{IP}_{3}$ as universal second messengers the inability of $\mathrm{NE}$ to sustain tone in the absence of extracellular $\mathrm{Ca}^{2+}$ suggests that ET-1 and SRTX-b must be producing something in addition to DAG and $\mathrm{IP}_{3}$ which could not be determined by my protocola. However, the demonstration by Price et al. (1989) that oncogenlc ras could stimulate phosphatidylcholine hydrolysis, diacylglycerol releage and arachidonic acid production without altering inositol phosphate levels In SWIEs-3T3 colls is consistent with the findings of Hirata et al. (1988a) concerning the actions of ET-1 in vascular smooth muscle cells. Furthermore, the demonstration that $E T-1$ is a potent mitogen which otimulates c-myc and cfos proto-oncogene expression (see review by Simonson and Dunn, 1990b) leaves room for epeculation that oncogenic ras can be stimulated by ET-1 and SRTX-b. oncogenically activated ras proteins contain single amino acid substitut Lons and are generally unresponsive to Grpase activating protein, a collular proteln that stimulates GTP hydrolysis by normal p21 rar (Trahey and McCormick, 
1987) in an "active" (GTP-bound) conformation. Price et al. (1989) have suggested that ras rapidly activates a number of cellular signalling systems, leading to a sustained increase in diacylglycerol levels. In contrast, Sunako ot al. (1990) propose a phospholipase C system generating IP 3 and DAG as an explanation for ET-1 induced changes in diacylglycerol during sustained tone. Sunako et al. (1990) do concede that there could be other mechaniams of DAG production. The suggestion by Price et al. (1989) fits the Rasmusgen (1986) model of sustained cellular response and would, perhaps, explain the basis of ET-1 and SRTX-b sustained tone in the absence of extracellular $\mathrm{Ca}^{2+}$. Additional studies are required to address this matter.

By far the most important cc elusion derived from the ryanodine studies is that IP3 may not be the intracellular $\mathrm{Ca}^{2+}$ mobilizer for contractione Induced by ET-1 or SRTX-b whereas those induced by NE have a Bignificant IP3 dopendency. Based on the characterieties of $\mathrm{SQ}$ and $\mathrm{S} \beta$ intracellular $\mathrm{Ca}^{2+}$ stores (Iino et al., 1988), and the emergent " $\mathrm{L}$ " and " $\mathrm{N}$ "-like $\mathrm{Ca}^{2+}$ channel ut111zation by ET- 1 and " $L$ " and " $T$ " type $\mathrm{Ca}^{2+}$ channel ut111zation by SRTX-b (Inoue et a1., 1990; Lawson and Chatelain, 1989; Topouzis et al., 1989), it can be postulated that the primary electrophysiologic event in the action of these peritides involves the opening of "N"-like or "T"-type $\mathrm{Ca}^{2+}$ channels with a regultant $\mathrm{Ca}^{2+}$ induced $\mathrm{Ca}^{2+}$ release from Sa otores initiating contraction. Maintenance of tone is brought about by activation of protein kinase $c$ with sustained levels of diacylglycerol not involving the inositol phosphate pathway. NE can be postulated to act via the activation of " $L$ " and "T" type $\mathrm{Ca}^{2+}$ channels leading to $\mathrm{Ca}^{2+}-$ induced $\mathrm{Ca}^{2+}$ release to initiate contraction. However, there is a dependence on extracellular $\mathrm{Ca}^{2+}$ to sustain activity of diacylglycerol and protein kinage $c$ to maintain tone. The sharp spike of 
contraction induced by $\mathrm{NE}$ in a $\mathrm{Ca}^{2+}-$ free medium is likely due to IP,-mediated moblization of $\mathrm{Ca}^{2+}$ from $\mathrm{SB}$ stores. The non-malntenance of tone $\mathrm{is}$ due to the reaccumulating property of $S B$ stores thereby reducing intracellular $\mathrm{Ca}^{2 *}$ to a level below which the diacylglycerol and protein kinase $c$ activity cannot be maintained. The absence of the characteristic spiked contraction for the two peptides is evidence that the SB store is not $\mathrm{stimulated} \mathrm{by} \mathrm{ET-1}$ and SRTX-b. This also explaing the the ability of NE, in the absence of extracellular $\mathrm{Ca}^{2+}$, to mobillze intracellular $\mathrm{Ca}^{2+}$ from $\mathrm{S} \alpha$ and $\mathrm{SB}$ as opposed to the peptide use of $\mathrm{S} \alpha$ stores pradominantiy. In a $\mathrm{Ca}^{2+}$-froe medium, $\mathrm{NE}$ leads to the production of $I P_{3}$ which mobilizes $S B \mathrm{Ca}^{2+}$ to release $\mathrm{Ca}^{2+}$ from $\mathrm{Sa}$ stores to generate the phasic contraction. The rapid reaccumulation characteristicg of $\mathrm{S} \beta$ stores lowers $\mathrm{Ca}^{2+}$ below a critical level for contraction while $\mathrm{IP}_{3}$ is metabolized. I further speculate that the small slowly rising tone of peptide fnduced contraction may be due to activation of oncogenic ras with production of diacylglycerol which, in association with protein kinase $\mathrm{C}$, can function at low intracellular $\mathrm{Ca}^{2+}$ levels. Thua, large contractions may be dependent on $\mathrm{Ca}^{2+}$-induced $\mathrm{Ca}^{2+}$ release fostered by the entry of extracellular $\mathrm{Ca}^{2+}$ through " $\mathrm{L}$ ", "T", "N" or, perhaps, non-8pecific cation channels.

The effects of NDGA have been clearly demonstrated to be speciflc for lipoxygenase products which could be generated from arachidonle acid derived from either the phosphatldylinositol or the phosphatidylcholine pathway.

Further electrophysiologic characterization of the $\mathrm{Ca}^{2+}$ channel types in smooth muscle, as well as the effect of proto-oncogenes induced by ET-1 and SRTX-b, will be needed to completely characterize the physiologic effects of thege peptides. The differences in the cell signalling processes in vascular 
versug non-vascular pmooth muscle demonstrated in this atudy aggest that SRTX-b anr. aT-1 may not act on a homogeneous receptor population. other evidence in the literature is also indicative of receptor subtypeg for these related peptides (Webb, 1991).

In conclusion, my studies indicate that ET-1 inftiates contraction in the rat thoracic aorta and anococcygeus by depolarizing the plaema membrane with a regultant Influx of $\mathrm{Ca}^{2+}$ through voltage-operated channela and nonspecific cation channels. The incoming $\mathrm{Ca}^{2+}$ leads to calcium induced calcium release from the $s \alpha$ stores. Intracellular calcium, having risen above the critical concentration activates phospholipase $A_{2}$ to produce 5-1ipoxygenase products to sustain the contraction. In the latter tonic phase, activation of ras oncogene produces sustained levels of diacylglycerol which, in association with protein kinase C, maintains tone for long periods even in the face of a diminghing calcium concentration. The major membrane 1ipld catabolized is most probably phosphatidylcholine rather than phomphatidylinositol (see review by Exton, 1988).

A summary of the aignalling processes that are involved is represented In Figure 37. 
Figure 37: Schematic summary of cell signaling processes in smooth muscle activated by ET, SRTX, NE. DHP, dihydropyridine; PLC, phospholipase C; DAG, diacylglycerol; PLA 2 , phospholipase $A_{2}$; PKC, protein kinase C, G?, G-protein. 


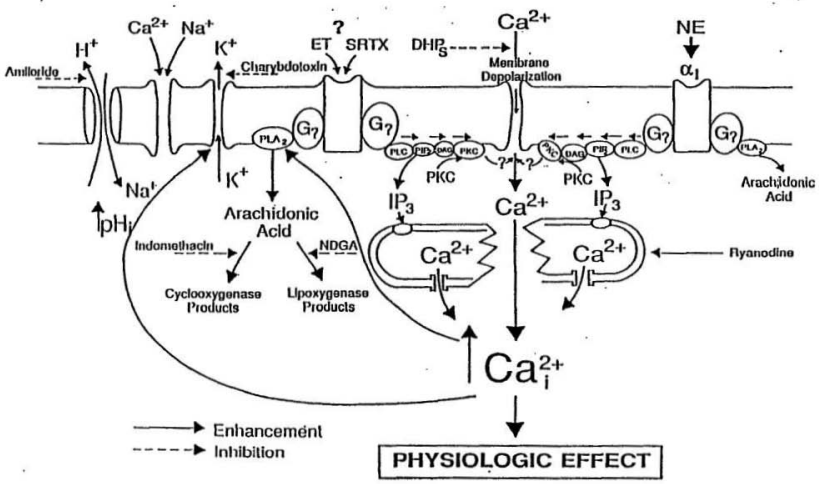




\section{REFERENCES}

Ambar, I., Kloog, Y., Schvartz, I., Hazum, E. and Sokolovaky, M. (1989) competitive interaction between endothelin and sarafotoxin: binding and phosphoinositide hydrolysis in rat atria and brain. Biochem. Biophys. Res. Commun. 158, 195-201.

Ando, K., Hirata, Y., Shichiri, M., Emori, T. and Marumo, F. (1989) Presence of immunoreactive endothelin in human plasma. FEBS Lett. 245, 164-166.

Ando, J., Komatsuda, T. and Kamiya, A. (1988) Cytoplasmic calcium response to fluid shear stregs in cultured vascualr endothelial cello. In vitro 24, $871-877$.

Arai, H., Hori, S., Aramori, I., Ohkubo, H. and Nakanishi, S.(1990) Cloning and expression of a CDNA encoding an endothelin receptor. Nature 348 , 730-732.

Auch-Schwelk, w., Katuszic, z. and Vanhoutte, P.M. (1989) Contractions to oxygen derived free radicals are augmented in the aorta of the spontaneously hypertensive rat. Hypertension 13, 859-864.

Auguet, M., Delaflotte, S., Gullion, J.M., Rouberg, P., Chabrier, P.E., Braquet, P. (1990) Endothelin-1, but not sarafotoxin s6b, Induces crossdesensitization of rat aorta contraction. Eur. J. Pharmacol. 187, 293-294.

Auguet, M., Delaflotte, S., Chabrier, P.B., Pirotzky, E., Clostre, F. and Braquet, P. (1988) Endothelin and $\mathrm{Ca}^{2+}$ agonisi Bay $\mathrm{K}$ 8644: different vasoconstrictive properties. Biochem. Biophys. Res. Commun. 156, 186-192.

Badr, K.F., Murray, J.J., Breyer, M.D., Takahasi, K., Inagami, T. and Harris, R.C. (1989) Mesangial cell, glomerular and renal vascular responses to endothelin in the rat kidney. $J$. clin. Invest. $83,336-342$.

Bdolah, A., Wollberg, z., Fleminger, G. and Kochva, E. (1989) SRTX-d, a new native peptide of the endothelin/sarafotoxin family. FEBS Lett. 256, 1-3.

Bean, B.p. (1985) Two kinds of calcium channels in canine atrial cella. Differences in kinetics, selectivity and pharmacology. J. Gen. Physiol. , $1-30$.

Bean, B.P. (1989) Classes of calcium channels in vertebrate cells. Annu. Rev. Physio1. 51, 367-385.

Benham, C.D. and Tsien, R.W. (1987) A novel receptor-operated Ca $\mathrm{C}^{2+}$-channel activated by ATP in smooth muscle. Nature (Lond.) 328, 275-278.

Berridge, M.J. (1985) The molecular basis of communication within the cell. Sci. Anex. 53, 142-152. 
Berridge, M.J. and Irvine, R.F. (1984) Inositol trisphosphate, a novel second messenger in cellular signal transduction. Nature 312, 315-321.

Besch, H.R. (1985) Effects of ryanodine on cardiac subcellular membrane fractione. Fod. Proc. 44, 2960-2963.

Bevan, J.A., Bevan, R.D., Hwa, J.J., Owen, M.P., Tayo, F.M. and Winquist, R.J. (1982) Calcium extrinsic and intrinsic (myogenic) vascular tone. In: Calcium Modultors, Gorfiraind, T., Albertini, A. and Paloette, R, Eds., pp. 125-132. Elsevier, Amsterdam.

Bieger, D. and Triggle, C. (1985) Pharmacological properties of mechanical responses of the rat oesophageal muscularis mucosae to vagal and field gtimulation. Br. J. Pharmacol. 84, 93-106.

Boarder, M.R. and Mariott, D.B. (1989) Characterization of endothelin-1 atimulation of catecholamine release from adrenal chromafin cella. $J$. Cardiovase. Pharmacol. 13 (Suppl. 5), S223-s224.

Bocekino, S.B, Blackmore, P.F, and Exton, J.H. (1985) Stimulation of 1,2diacylglycerol accumulation in hepatocytes by vasopressin, epinephrine and angiotensin Ir. J. Biol. Chem. 260, 14201-14207.

Bolton, T.B. (1979) Mechanisms of action of transmitters and other substances on smooth muscle. Physiol. Rev. 59, 606-718.

Borges, R., Von Grafenstein, H. and Knight, D.E. (1989) Tissue selectivity of endothelin. Eur, J. Pharmacol. 165, 223-230.

Brain, S.D. (1989) The direct observation of arteriolar constriction induced by endothelin in vivo. Eur. J. Pharmacol. 160, 401-403.

Brody, M.J., Haywood, J.R. and Touw, K.B. (1980) Neural mechanisms in hypertension. Ann. Rev. Physiol. 42, 441-453.

Burch, R.M., Luini, A. and Axelrod, J. (1986) Phospholipase $A_{2}$ and phosphollpase $\mathrm{C}$ are activated by distinct GTP binding proteing in response to $\alpha_{1}$-adrenergic stimultion Ln FRTL5 thyrold cells. Proc. Nat1. Acad. Sci. U.S.A. 83, 7201-7205.

Carafoll, E. and Penniston, J.I. (1985) The calcium signal. Sci. Amer. 261, 6673.

Cassel, D. and Selinger, z. (1976) Catecholamine-stimulated GTPase activity in turkey erythrocyte membranes. Biochem. Biophys. Acta 452, 538-551.

Cernacek, P. and Stewart, D.J. (1989) Imnunoreactive endothelin in human plasma: marked elevations in patients in cardiogenic shock. Biochem. Biophys. Res. Commun. 161, 562-567.

Chadwick, C., Saito, A. and Fleischer, s. (1990) Isolation and characterization of inositol trisphosphate receptor from smooth muscle. 
Proc. Nat1, Acad, Sei, U.S.A. 87, 2132-2136.

Chapman, R.A. (1979) Excitation-contraction coupling in cardiac muscle. Prog. Biophys. Hol. Biol. $35,1-52$.

Chen, G. and Suzuki, H. (1990) Calcium dependency of the endothelium-dependent hyperpolarization in smooth muscle cells of the rabbit carotid artery. $J$. Physiol. 421, 521-534.

Cherry, P.D., Furchgott, R.F., Zawadzki, J.V. and Jothlanandan, D. (1982) The role of endothelial cells in the relaxation of isolated arteries by bradykinin. Proc. Nat1. Acad. Sci. U.S.A. 79, 2105-2110.

Cocks, T.M. and Angus, J.A. (1983) Endothelfum-dependent relaxation of corcnary arteries by noradrenaline and serotonin. Nature 305, 627-630.

Cohen, P. (1979) The hormonal control of glycogen metaboliem in mammallan musele by multivalent phosphorylation. Biochem, Soc. Trans. 7, 459-480.

Cozza, E.N., Gomez-Sanchez, C.E., Foecking, M.F. and Chiou, S. (1989) Endothelin binding to cultured calf adrenal zona glomeruloga cells and stimulation of aldosterone secretion. J. Clin. Invest. 84, 1032-1035.

Creed, K.E. and Gillesple, J.S. (1973) The effect of excitatory or inhibitory nerve atimulation on the membrane potential of the rat anococcygeus muscle. J. Physio1, 237, 47-48.

Creed, K.E., Glllegple, J.S. and Muir, J.C. (1975) The electrical basis of exictation and inhibilton in the rat anococcygeus mugcle. J. Physiol. 245: $33-47$.

Criscione, L., Thomann, H., Rodriguez, C., Eglème, C. and Chiesi, M. (1989) Blockade of endothelin-induced contract lons by dichlorobenzamil: mechaniams of action. Biochem. Biophys. Res. Commun. 163, 247-254.

D'Orleans-Juste, P., Dellucci, G. and Vane, J.R. (1989) Endothelin-1 contracts isolated vessels independently of dihydropyridine-senoitive $\mathrm{Ca}^{2+}$ channel activation. Eur. J. Pharmacol. 165, 289-295.

DeLean, A., Stadel, J.M. and Lefkowitz, R.J. (1980) A ternary complex model explaing the agonist-apecific binding properties of adenylate cyclasecoupled B-adrenergle receptor. J. Biol. Chent. 255, 7108-7117.

DeMey, J.G. and Vanhoutte, P.M. (1982) Heterogenous behaviour of the canine arterial and venous wall: Importance of the endothelium, Circ, Res. 51, 439-447.

DeNey, J.G. and Vanhoutte, P.M. (1983) Anoxia and endothelium-dependent reactivity of the canine femoral artery. J. Physiol. (Lond.) 335. 65-74.

deNuccl, G., Thomas, R., D'Orleans-Juste, P., Antunes, E., Walder, C., Warner, T.D. and Vane, J.R. (1988) Preggor ef fects of clrculating endothelin are 
limited by ito removal in pulmonary circulation and by the release of proatacyelin and endothelium-derived relaxation factor. Proc. Matl. Acad. Sci. U.S.A. 85, 9797-9800.

Deth, R. and van Breemen, c. (1977) Relative contributions of $\mathrm{Ca}^{2+}$ Influx and cellular $\mathrm{Ca}^{2+}$ release during drug induced activation of rabbit aerta. Pfluggers Arch. Eur. J. Physiol. 348, 13-23.

Devine, C.E., Somlyo, A.V. and Somlyo, A.P. (1972) sarcoplasmic reticulum and excitation contraction coupling in mammalian mooth muscles. J. Cell Biol. $52,690-718$.

Dominiczak, A.F. and Bohr, D.F. (1990) Cell membrane abnormalities and the regulation of intracellular calcium concentration in hypertension. Clin. Sci, $79,415-423$.

Ebashl, S., Mikawa, T., Hirata, M. and Nonomura, Y. (1978) The regulatory role of calclum in muscle. Ann. N.Y. Acad. Sci. 307, 451-461.

Eglen, R.M., Michel, A.D., Sharif, N.A., Swank, S.R. and Whiting, R.L. (1989) The pharmacological properties of the peptide, endothelin. Br. J. Pharmacol. 97, 1297-1307.

Emori, T., Hirata, Y., ohata, K., Shichiri, M. and Marumo, F. (1989) Secretory mechanisms of immunoreactive endothelin in cultured bovine endothelial cells. Biochem. Biophys. Res. Commun. 160, 93-100.

Exton, J.H. (1988) Mechanisms of action of calclum-mobllizing agonlsts: some variations on a young theme. FASEB J. 2, 2670-2676.

Feletou, M. and Vanhoutte, P.M. (1988) Endothelium-dependent hyperpolarization of canine coronary artery smooth muscle. Br. $J$. Pharmaco1. 93, 515-524.

Fitzpatrlck, D.F. and szentivanyi, A. (1980) The relationship between increased myogenic tone and hyper-respongiveness in vascular smooth muscle of spontaneously hypertenaive ratg. Clin. Exp. Hypertens. 2, 1023-1037.

Fleming, W.W., Westfall, D.P., De La lande, I.S, and Jehlett, L.B. (1972) Lognormal distribution of equieffective doses of norepinephrine and acetyleholine in soveral tiogues. J. Pharmacol. Exp. Ther. 181, 339-345.

Fleminger, G., Bousso-Mittler, D., Bdolah, A., Kloog, Y. and Sokolovaky, M. (1989) Immunological and structural characterization of sarafotoxin/ondothelin family of peptides. Biochem. Biophys. Res. Comnun. $162,1317-1323$.

Folkow, B. (1990) "Structural factor" in primary and secondary hypertension. Hypertension 16, 89-101.

Forstermann, U., Troglsch, G. and Busse, R. (1984) specles-dependent differences in the value of endothellum-derived vascular relaxing factor. 
Eur. J. Pharmacol. 106, 639-643.

Fox, A.P., Nowycky, M.C. and Trien, R.W. (1987) Kinetic and pharmacologicai properties distinguishing three types of calcium currents in chick sensory neurones. J. physiol. 394, 149-172.

Fraser, C.L, and Sarnacki, P. (1990) Inositol 1,4,5-trisphosphate may regulate rat brain $\mathrm{Ca}^{2++}$ by inhibiting membrane bound $\mathrm{Na}^{+}-\mathrm{Ca}^{2++}$ exchanger. $\mathrm{J}$. Clin. Invest. $86,2169-2173$.

Frelssmuth, M., Casey, P.J. and Gilman, A.G. (1989) G-proteins control diverse pathways of transmembrane signaling. FASEB J. 3:2125-2131.

Frledman, M.E., Suarez-Kurtz, G., KaczorowskL, G.J., Katz, G.M. and Reuben, J.P. (1986) Two calcium currents in a smooth muscle cell line. Am. J. Physiol. 250, н699-H703.

Fv Lda, Y., Hirata, Y., Yoshimi, H., Takatsugu, K., Kobayashi, X., Yanagisawa, M. and Masaki, T. (1988) Endothelin is a potent secrotagogue for atrial natriaretic peptide in cultured rat atrlal myocyte. Blochem. Biophys. Res. Commun. 155, 167-172.

Furchgott, R.E., Zawadzki, J.V. and Cherry, P.D. (1981) Role of endothellum in vasodilator response to acetylchollne. In: Vasodilation, Vanhoutte, p. and Lensen, I., Eds., pp. 49-66, Raven, New York.

Furchgott, R.F. and zawadzki, J.v. (1980) The obligatory role of endothellal cells in the relaxation of arterial mooth mugcle by acotylcholine. Nature (Lond.) 288, 373-376.

Furchgott, R.F. (1988) Endothellum-dependent relaxation in systemic arteries. In: Relaxing and Contracting Factors; Blological and clinical Research, Paul M. Vanhoutte, Ed., pp. 1-26, clifton, NJ: Humana Press Inc.

Furchgott, R.F. (1983) Role of the endothellum in regpr:ses of vascular gmooth muscle. Circ. Res. 53, 557-573.

Galron, R., Kloog, Y., Bdolah, A. and Sokolovsky, M. (1989) Functional endothelin/sarafotox in receptors in rat heart myocytes: structure-activity relationships and receptor subtypes. Biochem. Biophys. Res. Commun. 163, 936-943.

Galron, R., Kloog, Y., Bdolah, A. and Sokolovsky, M. (1990) Different pathways of endothelial sarafotoxin-stimulated phosphoinositide hydrolysis in myocytes. Eur. J. Pharmacol. 188, 85-88.

Ganltkev1ch, V.Y. and Isenberg, G. (1990) Contribution of two types of calcium channels to membrane conductance of single myocytes from gulnea-pig coronary artery. J. Physiol. (Lond.) 426, 19-42.

Garcia-Sainz, J.A. and Hernandez-Sotomayor, S.M.T. (1985) Adrenergic regulation of gluconeogenesis: possible involvenent of two mechanism of 
signal trangduction in $\alpha_{1}$-adrenergic action. proc. Mat1. Acad. Sci. U,S.A. 82, $6727-6730$.

Gillesple, M.N., Owasoyo, J.O., McMurtry, I.F. and O'Brien, R.F. (1986) Sustained coronary vasoconstrietion provoked by a peptidergic substance released from endothelial cells in eulture. $J$. Pharmacol. Exp. Ther. 236, 339-343.

Gillespie, J.S. (1972) The rat anococcygeus muscle and 1 tg response to nerve stimulation and to some drugs. Br. J. Pharmacol. 45, 404-416.

Godfraind, T. and Miller, R.C. (1983) Specifieity of action of Cia entry blockers: comparison of their actions in the rat arteries and in human coronary arteries. Circ. Res. 52 (Suppl. 1) ra1-191.

Goetz, K.L., Wang, B.C., Madwed, J.B., zhu, J.L. and Leadley, R.J. Jr. (1988) Cardiovascular, renal and endocrine responses to intravenous endothelin in conscious dogs. Am. J. Physiol. 255, R1064-R1068.

Goetz, K., Wang, B.C., Loadley, R. (Jr.), 2hL, J.L., Madwed, J. and Ble, P. (1989) Endothelin and sarafotoxin produced dissimilar effects on renal blood flow, but both block the antidiuret lc effects of vasopresin. Proc. Soc. Exp. Biol. Hed. 191, 425-427.

Golby, F.S. and Beilin, L.S. (1972) Relationship between arterial pressure and the permeability of arterioles to carbon particles in acute hypertension in the rat. Cardiovasc. Res. 6, 384-390.

Goldberg, M.T. and Triggle, C.R. (1977) An analysis of the action of lanthanum on aortic tissue from normotensive and spontaneously hypertensive rats. Can. J. Physiol. Pharmacol. 55, 1084-1090.

Goto, K., Kasuya, K., Matsu1, N., Takuwa, Y., Kurihara, H., Ithikawa, T., Kimura, s., Yanagisawa, M. and Masaki, T. (1989) Endothelin activates the dihydropyridine-gensitive voltage-dependent $\mathrm{Ca}^{2+}$ channel in vascular smooth muscle. Proc. Natl. Acad. Sci. U.S.A. 86, 3915-3918.

Goyal, R.K. (1984) The anococcygeus nuscle; a promising smooth muscle preparation for the autonomic research. Ind. $J$. Pharmacol. 16, 68-78.

Graur, D., Bdolah, A., Wollberg, Z., Kochva, E. (1988/89) Homology between snake venom sarafotoxin and mammalian endothelin. Israel J. Zool. 35, 171-175.

Griffith, T.M., Edwards, D.H., Lewis, M.J., Newby, A.C. and Henderson, A.H. (1984) The nature of endothelium-derived vascular relaxant factor. Wature $308,645-648$.

Gustafson, T.L., EPISTAT : a statistical package designed for analyols of small data sets. Round Rock, TX 78664, U.S.A.

Hashimoto, T., Hirta, M., Itoh, T., Kanmura, X. and Kuriyama, H. (1986) Inositol 1,4,5-trisphosphate activates pharmacomechanical coupling in smooth muscle of rabbit mesenteric artery. J. Phystol. 370, 605-618. 
Hay, D.w.P. (1990) Mechanism of endothelin-induced contraction in guinea pig trachea: comparison with rat aorta. Br. - Pharmaco1. 100, 383-392.

Hickey, K.A., Rubanyi, G.M., Paul, R.J. and Highsmith, R.F. (1985) Characterization of a coronary vasoconstrictor produced by cultured endothellal cells. An. J. Physiol. 248, C550-C556.

Hirata, Y., Yoshimi, H., Takaichi, S., Yanagisawa, M. and Masak1, T. (198ab) Binding and receptor down regulation of a novel vasoconstrictor endothelin in cultured rat vascular smooth muscle cells. FEBS Lett. 239, 13-17.

Hirata, Y., Yoshimi, H., Kuramo, F., Watanabe, T.X., Kumagaye, S., Nakajima, K., Kimura, T. and Sakakibara, S. (1989) Interaction of synthetic sarafotoxin with rat vascular endothelin receptors. Biochem. Biophys. Res. Commun. $162,441-447$.

Hirata, Y., Yoshimi, H., Takata, S., Watanabe, T.X., Kumagai, S., Nakajlma, K. and Sakakibara, s. (1988a) Cellular mechanism of action by a novel vasoconstrictor endothelin in cultured rat vascular smooth muscle cells. Biochem. Biophys. Res. Commun. 154, 868-875.

Hisayama, T. and Takayanagh, T. (1988) Ryanodine: its possible mechanlam of action in caffeine-sensitive calcium store of gmooth muscle. pflugers Arch. 412, 376-381.

Huang, X-N., Yisayama, T., Takayanagi, I. (1990) Endothelin-induced contraction of rat aorta: contributions made by $\mathrm{Ca}^{2+}$ influx and activation of contractile apparatus associated with no change in cytoplasmic $\mathrm{Ca}^{2+}$ level. Naunyn-Schmiedeberg's Arch. Pharmacol. 341, 80-87.

Huttner, I., Boutet, H. and More, R. (1973) Studies on proteln passage through arterial endothelium. I. Regional differences in permeability to fine structural protein tracers in arterlal endothelium of normotensive rat. Lab. Invest. 28, 678-685.

Hwang, K.S. and van Breemen, c. (1987) Ryanodine modulation of ${ }^{45} \mathrm{Ca}$ ef flux and tension in rabbit aortic smooth muscle. Pflügers Arch. 408, 343-350.

Ignarro, L.J., Byrns, R., Buga, G.M., Wood, K.S. and Chaudhuri, G. (1987) Pharmacological evidence that endothelium derived relaxing factor is nitric oxide: use of pyrogallol and superoxide dismutase to study endothellumdependent and nitric oxide-elicited vascular amooth muscle rolaxation. $J$. Pharmaco1. Exp. Ther. 244, 191-189.

Iino, M., Kobayashi, T. and Endo, M. (1988) Use of ryanodine for functlonal removal of the calcium store in smooth muscle cells of guinea pig. Biochem. Biophys. Res. Commun. 152, 417-422.

Iino, M. (1987) Calcium depondent inositol trisphosphate induced calcium relesse in the guinea pig taenia caeci. Biochem. Biophys. Res. Commun. 142, 47-52.

Inoue, Y., Olke, M., Nakao, K., Kitamura, K. and Kuriyama, H. (1990) 
Endothelin augments unitary calcium currents on the smooth musele cell membrane of guinea-pig portal vein. J. Physiol. 423, 171-191.

Inoue, A., Yanagisawa, M., Kimura, S., Kasuya, Y., Miyauchi, T., Goto, K. and Masaki, T. (1989) The human endothelin family: Three structurally and pharmacologically distinct lsopepties predicted by three separate genea. Proc. Nat1. Acad. Sei. U.S.A. $862863-2867$.

Irving, H.R. and Exton, J.H. (1987) Phosphatidylcholine breakdown in rat liver plasma membranes. J. Biol. Chem. 262, 3440-3443.

Ishikawa, T., Yanagisawa, M., Kimura, S., Goto, K. and Masaki, T. (1988b) Positive chronotropic action of endothelin, a novel endothelium-derived vasoconstrictor peptide. Pflugers Arch. 413, 108-110.

Iahikawa, T., Yanagiaawa, M., Kimura, S., Goto, K. and Masaki, T. (1988a) Positiva inotropic action of novel vasoconstrictor peptide endothelin on guinea pig atria. Am. $J$. Physiol. 255, H970-H973.

Israel, M., Dunant, Y. and Manaranche, R. (1979) The present status of the vesicular hypothesis. Prog. Neurobiol. 13, 237-275.

Itoh, Y., Yanagisawa, M., ohkubo, S., Kimura, C., Kosaka, T., Inoue, A., Ishida, N., Mitsui, Y., Onda, H., Fujino, M. and Masaki, T. (1988) cloning and sequence anlaysis of CDNA encoding the precursor of a human endotheliumderived vasoconftrictor peptide, endothelint identity of human and porcine endothelin. FEBS Lett. 231, 440-440.

Janis, R.A. and Triggle, D.J. (1973) Effect of diazoxide on aortic reactivity to calcium in spontaneously hypertensive rats. Can. $J$. Physiol. Pharmacol. 51, 621-626.

Jenden, D.J. and Fairhurst, A.S. (1969) The pharmacology of ryanodine. Pharmacol. Rev. 21, 1-25.

Jones, C.R., Hiley, C.R., Pelton, J.T. and Mohr, M. (1989) Autoradiographic visualization of the binding sites for $\left(^{125}\right.$ I) endothelin rat and human brain. Neurosci. Lett. 97, 276-279.

Kamm, K.E. and Stul1, J.T. (1985) The function of myosin and myosin light chain kinase phosphorylation in smooth muscle. Ann. Rev. Pharmacol. Toxicol. $25,593-620$.

Katugic, z.S., shepherd, J.T. and Vanhoutte, P.M. (1984) Vasopressin causea endothelium-dependent relaxation of the canine basilar artery. Circ. Res. 55, 575-579.

Katusic, z.s., Shepherd, J.T., Vanhoutte, P.M. (1597) Endothelium-dependent contractions to stretch in canine basilar arteries. Am. J. Physiol. 252, H671-H673.

Khalil, R.A. and van Breemen, c. (1990) Intracellular free calcium 
concentration/force relationship in rabbit inferior vena cava activated by norepinepehrine and high $\mathrm{x}^{*}$. Pflugers Arch. Eur. J. Physiol. 416, 727-734.

Kimura, s., Kasuya, Y., Sawamura, T., Shinmi, O., Sugita, Y., Yanagiøawa, K., Goto, K. and Masaki, T. (1988) Structure activity relationship of endothelin: importance of the C-terminal molety. Biochem. Biophys. Res. Commun. 156, 1182-1186.

Kloog, Y., Bousso-Mittler, D., Bdolah, A. and Sokolovsky, M. (1989) Three apparent receptor subtypes for endotholin/garafotoxin family. FEBS Lett. 253, 199-202.

Kloog, Y., Ambar, I., Sokolovsy, M, Kochva, E., Wollberg, z. and Bdolah, z. (1988) Sarafotoxin, a novel vasoconetrictor peptide: phoaphoinoaitide hydrolysis in rat heart and brain. Science 242, 268-270.

Kloog, Y. and Sokolovsky, M. (1989) similaritles in mode and sites of action of sarafotoxing and endothelins. Trends in P.rarmacol. Sci. 10, 47-49.

Knight, D.E. and Baksr, P.F. (1982) Calcium-dependence of catecholamine releaвe from bovine adrenal medullary cells after exposure to intense electric fieldg. J. Membr. Biol. 68, 107-140.

Kochva, E., Viljoen, C.C. and Botes, D.P. (1982) A new type of toxin in the venom of snakes of the genus itractaspls (Atractaspideinae). Toxicon 20, 581-592.

Kojima, I., Kojima, K. and Rasmugsen, H. (1985) Intracellular caleium and adenosine $3^{\prime}, 5^{\prime}$-cyclic monophosphate as mediators of potassium-induced aldosterone secretion. Bfochem. J. 228, 69-76.

Kokesi, c., Imai, M., Hirata, Y., Yanagisawa, M. and Masaki, T. (1989) Autoradiographic distribution in rat tisaues of binding sites for endothelin: a neuropeptide? Am. J. Physiol. 256, R858-R866.

Komuro, I., Kurihara, H., Siugiyama, T., Takaku,F. and Yazaki, Y. (1988) Endothelin stimulates $c-f o s$ and c-myc expression and proliferation of vascular smooth muscle celle. FEBS Lett. 238, 249-252.

Kuno, M. and Gardner P. (1987) Ion channels activated by inositol 1,4,5trisphosphate in plasma membrane of human $\mathrm{T}$-1ymphocytes. Nature (Lond.) $326,301-304$.

Kurihara, H., Yoshlzumi, M., Sugiyama, T., Takaku, F., Yanagisawa, M., Masaki, T., Hamaoki, M., Kato, H. and Yazaki, Y. (1989) Transforming growth factor- $\beta$ stimulates the expression of endothelin mRNA by vascular endothalial cells. Biochem. Biophys. Res. Commun. 159, 1435-1440.

Kwan, c.Y. (1985) Caleium-handling defects and amooth muscle pathophysiology, in Calcium and Contractility, Smooth Muscle, Grover, A.K. and Daniel, E.E., Eds., Humana Press, Clifton, NJ 299-325.

Lakatta, E.G., Capograssi, M.C., Kort, A.A. and Stern, M.D. 
Spontaneous myocardial calcium oscillations: overview with emphasis on ryanodine and caffeine. Fed. Proc. 44, 2977-2983.

Lawson, K. and Chatelain, P. (1989) Contractions of rat aorta to endothelin are eensitive to nickel and cadmium lons but not to nicardipine or $w$-conotoxin. Br. J. Phamacol. 98,840 p.

Leijten, P.A.A. and van Breemen, C. (1984) The effects of caffeine on the noradrenaline-sensitive caleium store in rabbit aorta. J. Physfol. 357, $327-339$.

Lin, W.W., Lee, C.Y. and Chuang, D. M. (1989) Cross desensitization of endothelin and sarafotoxin-induced phosphoinositide turnover. Eur. J. Pharmaco1. 166, 581-582.

Loeb, A.L. and Peach, M.J. (1989) F'dothelial and smooth mugcle interacciong in hypertension. In: Blood VGujel changes in Hypertension: structure and Function, R.M.K.w. Lee, Ed., Vol. I, 25-44.

Long, C.J., Shikano, K, and Berkowitz, B.A. (1987) Anion exchange resins discriminate between nitric oxide and EDRF. Eur. J. Pharmacol. 142, 317318.

Lund-Johansen, P. (1977) Hemodynamic alteration in hypertension-spontaneous changes and effects of drug therapy. A review. Acta Med. Scand. (603) Suppl., 1-14.

Lüscher T.F. and Vanhoutte, P.M. (1986) Endothelium-dependent contractions to acetylcholine in the aorta of the spontaneously hypertensive rat. Hypertension $8,344-348$.

Lüscher, T.F. (1990) The endothellum: target and promoter of hypertension. Hypertension 15, 482-485.

MacCumber, M.W., Ross, C.A. and Snyder, S.H. (1990) Endothelin in brain: receptors, mitogenesis and biosynthesis in gilal cells. Proc. Nat1. Acad. SCi. U.S.A. 87, 2359-2363.

MacCumber, M.W., Ross, C.A., Glaser, B.M. and Snyder, S.H. (1989) Endothelin: visualization of mRNAs by in situ hybridization provides evidence for local action. Proc. NatI. Acad. Sci. U.S.A. 86, 7285-7289.

Maggi, C.A., Giulani, s., Patacchini, R., Santicioli, R., Turini, D., Barbant1, G. and Meli, A. (1989) The C-terminal hexapeptide, endothelin-(16-21), discriminate between different endothelin receptorg. Eur. J. Pharmacol. $166,121-122$.

Marshall, J.J. and Kontos, H.A. (1990) Endothelium-derived relaxing factors: a perspective from in vivo data. Hypertension 16, 371-386.

Martin, W., Villani, G.M. Jothianandan, D. and Furchgott, R.F. (1984) Selective blockade of endothelium-dependent and glycerol trinltrate-induced 
relaxation by hemoglobin and by methylene blue in the rabbit aorta. $J$. Pharnacol. Exp. Ther. 232, 708-716.

Matsuda, J.J., Volk, K.A. and Shibata, E.F. (1990) Calcium currents in loolated rabblt coronary arterial smooth muscle myocytes. J. Physiol. (Lond.) 427, $657-680$.

Mellander, S. and Johansson, B. (1968) Control of resiatance, exchange, and capacitance functions in peripheral circulation. Pharmacological Revievs 20, 117-196.

Miasiro, N. and Paiva, A.C.M. (1990) Homologous desensitization of the effectu of endothelin on rabbit aortic rings and on cultured rat aorta emooth mugcle cells. Eur. J. Pharmacol. 179, 151-158.

Miller, V.M., Aarhus, L.I. and Vanhoutte, P.M. (1986) Modulation of endothelium-dependent responses by chronic alterations of blood flow. Am. J. PhysiOL. 251, H52O-H527.

Miller, R.J. (1987) Multiple calcium channels and neuronal function. Science $235,46-52$.

Miller, V.M. and Vanhoutte, P.M. (1985) Endothelial az-adrenoceptors in canine pulmonary and aystemic blood vessels. Eur. J. Pharmacol. 118, 123-129.

Miller, V.M. and Vanhoutte, P.M. (1989) Is nitric oxide the only endothellumderived relaxing factor in canine femoral veins? Am. J. Physiol. 257, H1910-H1916.

Minneman, K.P. (1988) $\alpha$-Adrenergic receptor subtypes, inositol phosphates, and sources of cell $\mathrm{Ca}^{2+}$. Pharmacol. Rev. 40, 87-119.

Morgan, J.P. and Morgan, K.G. (1984) Stimulus-speciflc patterns of intraceliular calcium levela in amooth muscle of ferret portal vein. $J$. Physiol. (Lond.) 351, 155-167.

Mulvany, M.J. (1989) Contractile properties of resistance veseels related to cellular function. In Blood Vessel Changes in Hypertensiont structure and Function, R.M.K.W. Lee, Ed. pp. 1-24. Boca Raton, Florida: CRC Presa Inc.

Myers, P.R., Guerra, R. Jr., Bates, J.N. and Harrison, D.G. (1989) Studies on the properties of endothelium-derived relaxing factor (EDRF), nitric oxide, and nitrosolthiols: Similarities beween EDRF and S-nitroso-L-cysteine (CysNo). J. Vasc. Med. Biol. 1: 106.

Nakajima, K., Kumagaye, S., Nishio, H., Kuroda, H., Watanabe, T.X., Kobayashi, Y., Tamaoki, H., KLmura, T. and Sakakibara, S. (1989) Synthesi. of endothelin-1 analogues, endothelin-3 and sarafotoxin S6b: structuroacti: ity relationships. J. Cardiovasc. Pharmacol. 13 (Suppl. 5), S8-512.

Nayler, W.G. (1990) Endothelin: isoforms, binding sited and posaible implications 
in pathology. Trends in Pharmeol. Sct. 11, 96-99.

Nomora, A., Uchida, Y., Kameyama, M., Saotome, K., Oki, K. and Hasegawa, S. (1989) Endothelin and bronchial asthama. Lancet 11, 747-748.

Nowycky, M.C., Fox, A.P, and Tsien, R.W. (1985) Three types of neuronal calcium channel with different calcium agonist aensitivity. Nature (Lond.) 316 , $440-443$.

O'Brien, R.F. and McMurtry, I.F. (1984) Endothelial cell supernates contract bovine pulmonary artery rings. An. Rev. Respir. 126, A337 (abstr).

Ohlatein, E.H., Horohonich, S. and Hay, D.w.P. (1989) Cellular mechanisms of endothelin in rabblt aorta. J. Pharmacol. Exp. Ther. 50, 548-555.

Oortglesen, M., van Kleef, R.G.D.M. and Vijverberg, H.P.M. (1990) Novel type of ion channel activated by $\mathrm{Pb}^{2+}, \mathrm{Cd}^{2+}$ and $\mathrm{AL}^{\text {st }}$ in cultured mouse neuroblastoma cells. J. Mombr, Biol. 113, 261-268.

Orlowo, M.A. (1984) Effect of calcium entry blockers and divalent cations on noradrenaline induced contractions of the rat anococcygeus muscle. Arch. Int. Pharmacodyn. Ther. 271, 45-52.

Owen, D.G., Segal, M. and Baker, J.L. (1986) Voltge-clamp analysis of a Ca ${ }^{2+}$ and voltage-dependent chloride conductance in culture mouse spinal neurons. J. Neurophysio1. 55, 1115-1135.

Palmer, R.M.J., Ferrlge, A.G. and Moncada, S. (1987) Nitric oxide release accounts for the biologlcal activity of endothelium-derived relaxing factor. Nature $327,524-526$.

Patel, A.I. and Triggle, C.R. (1986) Pharmacological characterisation of calcium channela in vascular smooth muscle from hypertensive and normoteneive animals. Unpublished M.Sc. Thesis, Memorial University of Newfoundland.

Patridge, L.D. and Swandulla, D. (1988) Calcium activated non-specific cation channelø. Tronds Neurosei. 11, 69-72.

Peach, M.J., Loeb, A.L., Singer, H.A. and Saye, J. (1985) Endothellum-derlved vascular relaxing factor. Hypertension 7 (Suppl. I) I-94-I-100.

Pernow, J., Hemsén, A. and Lundberg, J.M. (1989) Tlasue speclfic distribution, clearance and vascular effects of endothelin in the pig. Biochem. Biophys. Res. Commun. 161, 647-653.

Price, B.D., Morris, J.D.H., Marshall, C.J. and HaL1, A. (1989) stimulation of phosphatidylchollne hydrolysis, diacylglycerol release, and arachidonic acid production by oncogenic ras is a consequence of protein kinase c activation. J. Biol. Chem. 264, 16638-16643.

Pohl, U., Busse, R, and Bassenge, E. (1987) Endothellal cells as oxygen sensors in Mechanisms of Vasodilation IV (Vanhoutte, P. M., ed.) Raven, New York. 
Rand, M.J. and Varma, B. (1970) The effects of chollnomimetic drugs on responses to sympathetic nerve stimulation and noradrenaline in the rabbit ear artery. Br. J. Pharmaco1. 38, 758-770.

Rapoport, R.M., Stauderman, K.A, and Highsmith, R.F. (1990) Effects of EDCF and endothelin on phosphatidylinositol hydrolysis and contraction in rat aorta. Am. J. Physio1. 258, C122-C131.

Rasmussen, H. (1989) The eycling of calcium as an intracellular messenger. sci. Amer. 261, 66-73.

Rasmussen, B. (1986) Calcium messenger system. New Engl. J. Mod. 314, 1094-1101 and $1164-1170$.

Rees, D.D., Palmer, R.M.J. and Moncada, S. (1989) Role of endothellum derived nitric oxide in the regulation of blood pressure. Proc. Nat1. Acad. Sci. U.S.A. $86,3375-3378$.

Resink, T.J., Scott-Burden, T., Boulanger, C., Weber, E. and Bühler, F. (1990) Internalization of endothelin by cultured human vascular smooth muscle cells: characterization and physlological significance. Mo1. Pharmacol. $38,244-252$.

Resink, T.J., scott-Burden, T. and Bühler, F.R. (1989) Activation of phospholipase $A_{2}$ by endothelin in cultured vascular gmooth musclo collo. Biochem. Biophys. Res. Commun. 158, 279-286.

Reynoldg, E.E., Mok, L.L.S. and Kurokawa, s. (1989) Phorbol estars dissociates endothelin-stimulated phosphoinositide hydrolysis and arachidonic acid release in vascular amooth muscle cella. Biochent. Biophys. Res. Commun. 160, 868-873.

Rimele, T.J. and Vanhoutte, P.M. (1983) Effects of Inhlbltors of arachidonic acid metabolism and calcium entry on responses to acetylacholine, potassium and norepinephrine in the isolated canine saphenous vein. J. Pharmacol. Exp. Ther. 225, 720-728.

Ringer, S. (1883) a third contribution regarding the influence of the Inorganic constituents of the blood on the ventricles contraction. J. Physiol. 4, 222-225.

Rodman, D.M., MeMurtry, I.F., Peach, J.L. and O'Brien, R.P. (1989) Comparative pharmacology of rat and porcine endothelin in rat pulmonary artery. Eur. J. Pharmacol. 165, 297-300.

Ru Hu, J., von Giarsdorf, R, and Lang, R.E. (1988) Endothelin has potent inotrople effect in rat atria. Eur. J. Pharmacol. 158, 275-278.

Rubanyi, G.M., MeKinney, M. and Vanhoutte, P.M. (1937) Biphasic release of endothelium-derived relaxing factor(s) by acetylcholine from perfured canine femoral arteries. Characterization of muscarinic receptors. $J$. Pharmaco1. Exp. Ther. 240, 802-808. 
Rubanyi, G.M. and Vanhoutte, P.M. (1987) Nature of endothellum-derived relaxing factor: are there two relaxing mediatora? Circ. Res. 34, 317-326.

Rubanyi, G.M., Wilcox, D.E. and Greenberg, S. (1989) studies on endothelium derived relaxing factor (EDRF) released from canine femoral arteries by acetylenoline (ACh) and its identity as nitric oxide (NO) (abatract). J. Vase. Med. Biol. J, 111 .

Rubanyi, G.M., Lorenz, R.R. and Vanhoutte, P.M. (1985) Bloassay of endothel lum-derived relaxing factor. Am. J. Physiol. 215, H1077-H1080.

Rubanyi, C.M. and Vanhoutte, P.M. (1985) Hypoxia releases a vasoconstrictor substance from the canine vascular endothelium. J. Physiol. (Lond.) 364, 45-56.

Salda, K., Mitaul, $\mathbf{x}$. and Ishida, $\mathrm{n}$. (1989) A novel peptide, vasoactive intestinal contractor of a new (endothelin) peptide family. J, Biol. Chem. 264, 14613-14616.

Sakata, K., Ozaki, H., Kwon, S.-C. and Karaki, H. (1989) Bffects of endothelin on the mechanical activity and cytosolic calcium levels in various typer of smooth muscle. Br. J. Phaxmacol. 98, 483-492.

Sakurai, T., Yanaglsawa, M., Takuwa, Y., Miyazaki, H., Kimura, S., Goto, K. and Masaki, T. (1990) Cloning of a CDNA encoding a non-isopeptide-selective subtype of the endothelin receptor. Nature $348,732-735$.

Sala, S. and Matteson, D.R. (1990) Single channel recordings of two types of calcium channels in rat pancreatic beta-cells. Biophys. $J$. 58, 567

-571 .

Sato, K., Ozak1, H. and Karakl, H. (1988) Multiple effects of caffeine on contraction and cytosolic free $\mathrm{Ca}^{2+}$ levels in vascular gmooth muscle of rat aorta. Naunyn-Schmiedeborg's Arch. Pharmacol. 338, 443-448.

Schofield, P.R. and Abbott, A. (1989) Molecular pharmacology and drug action: structural information casts light on ligand binding. rrends in Pharmaco1. Sci. 10, 207-212.

Scrlabine, A., Pan, $M$. and Vanhoutte, P.M. (1990) Effect of I1poxygenase inhibitors on $\mathrm{Ca}^{2+}$-induced songtriction of the rabbit ear artery. Gen. Pharmaco1. 21, 235-239.

Sharma, R.V. and Bhalla, R.C. (1989) Regulation of cytosolic free $\mathrm{Ca}^{2+}$ concentration in vascular smooth muscle cells by $A-$ and $C-k i n a s e s$. Hyportension 13, 845-850.

Shearman, M.S., Sekiguchl, K. and Nishlzuka, Y. (1989) Modulation of lon channel activity: a key function of proteln kinase $C$ enzyme family. Pharmacol. Rev. $41,211-237$.

Shiba, R., Yanagisawa, M., Miyauchi, T., Ishil, Y., Kimura, s., Uchiyama, Y., 
Masakl, T. and Goto, K. (1989) Elimination of Intravenous ly injected ET-1 from the clrculation of the rat. J. Cardiovasc. Pharmacol. 13 (Suppl. 5) s98-s101.

Shibata, S, Kuchil, M. and Taniguchi, T. (1975) Calciun flux and binding in the aortic smooth muscle from spontaneously hypertensive rats. Blood vessels 12 , 279-289.

Shichiri, M., Hirata, Y., Emori, T., OhLa, K., Nakajima, T., Sato, K., Sato, A. and Marumo, F. (1989) Secretion of endothelin and related peptides from renal epithelial cell lines. FBBS Lett. 256, 203-206.

Shimokawa, H., Aarhus, L.L. and vanhoutte, P.M. (1987) Porcine coronary arterles with regenerated endothelium have a reduced endothelium-dependent responsiveness to aggregating platelets and seretonin. Circ. Res. 61, 256270 .

Shinml, O., Kimura, S., Sawamura, T., Sugita, Y., Yoshizawa, T., Uchlyama, Y., Yanaglsawa, M., Goto, T., Masaki, T. and Kananzawa, I. (1989) Endothelln-3 is a novel neuropeptide: isolation and sequence determination of endothelin-1 and endothelin-3 in porcine brain. Biochem. Biophys. Res. comunun. $164,587-593$.

Silver, P.J. and Stull, J.T. (1982) Regulation of myosin light chain and phosphorylase phosphorylation in tracheal smooth muscle. J. Biol. Chom. $257,6145-6150$.

Simonson, M.s., Wann, S., Mene, P., Dubyak, G.R., Kester, M., Nakazato, X., Sedor, J.R. and Dunn, M.J. (1989) Endothelln stinulates phoapholipase C, $\mathrm{Na}^{+} / \mathrm{H}^{+}$exchange, $\mathrm{C}-\mathrm{fos}$ expression and mitogenesis in rat mesangial cells. J. Clin. Invest. 83, 708-712.

Simonson, M.S. and Dunn, M.J. (1990a) Endothelin: Pathways of transmembrane signalling, Hypertension 15 (Suppl. I), I5-I12.

Simonson, M.S. and Dunn, M.J. (1990b) Cellular signaling by peptides of the endothelin gene family. FASEB J. 4, 2989-3000.

Singer, H.A., Saye, J.H. and Peach, M.J. (1984) Effects of cytochrone P-450 Inhibitors on endothelium dependent relaxation of rabbit aorta. Blood vesse1s 21, 223-230.

Slivka, S.R. and Insel, P.A. (1987) $\alpha_{1}$-Adrenergic receptor modiated phosphoinositlde hydrolyais and prostaglandin $E_{2}$ formation in Madin-Darby canine kidey cells. J. Biol. Chem. 262, 4200-4207.

slivka, S.R. and Insel, P.A. (1988) bradykinin receptor-mediated

Phorbol ester and necmycin dissoclate polyphospholnositide hydrolyais in Madin-Darby canine kidney cells. $J$. Biol. Chem. 263, 14640-14647.

sokolovsky, M., Galron, R., Kloog, X., Bdolah, A., Indig, F.E., Blumberg, S. and 
Eleminger, G. (1990) Endothelins are more sensitive than sarafotoxing to neutral endopeptidase: posaible physiologic significance. Proc. Natl. Acad. Sci. U.S.A. 87, 4702-4706.

steingland, O.S., Furchgott, R.F. and Kirpekar, S.M. (1973) Inhibition of adrenergic neurotyanamission by parasympathetics in the rabbit ear artery. J. Pharmacol. Exp. Ther. 184, 346-356.

sturek, M. and Hermemeyer, K. (1986) Calclum and godium channels in opontaneously contracting vascular smooth muscle celle. Science 233, 475478.

Suglura, M., Snajdar, R.M., Schwartzberg, M., Badr, X.F. and Inaganl, T. (1989) Identification of two types of speclfle endothelin receptors in rat mesangial cell. Biochem. Biophys. Res. Commun. 163, 1396-1401.

Sunako, M., Kawahara, Y., Hirata, K., Tsuda, T., Yokoyama, M., Fukuzaki, H. and rakal, Y. (1990) Mass analysis of 1,2-dlacylglycerol in cultured rabbit vascular amooth muscle cellg; comparigons of gtimulation by angiotensin II and endothelin. Hypertension 15, 84-88.

Sutko, J.L., Ito, K. and Senyon, J.L. (1985) Ryanodine: a modlfler of earcoplasmic reticulum calcium release in strlated muscle. Fed. proc. 44, 2984-2988.

Sutter, M.C. and Ljung, B. (1977) Contractility, muscle mass and agonist sensitivity of loolated portal veins from normo- and hypertensive rats. Acta Physiol. Scand. 99, 484-495.

Suzuki, N., Matsumoto, H., Kitada, C., Yanagisawa, M., Miyauchi, T., Masaki, T. and Fujino, M. (1989) Imnunoreactive endothelin-1 in plasma detected by sandwich-type enzyme immunoassay. J. Cardiovase. Pharmaco 2. 13 (Supp1. 5) s151-s152.

Tabrizchi, R. and Triggle, C.R. (1990) comparison between the vasoactive actions of endothelin and arginine vasopressin in pithed rata after pretreatment with Bay K 8644, nifedipine or pertussis toxin. J. Pharmacol. Exp. Ther. 253, 272-276.

Tabuchi, Y., Nakamura, M., Rakugi, H., Nagano, K., Mikami, H. and Ogihara, T. (1989) Endothelin inhiblts presynaptic adrenergic neurotransmission in rat mesenteric artery. Biochem. Biophys. Res. Comnun. 161, 803-808.

Takasaki, C., Tamiya, N., Bdolah, A., Wollberg, z. and Kochva, E. (1988) Sarafotoxins S6: several isotoxins from Atractaspis engaddensis (burrowing agp) venom that affect the heart. Toxicon 26, 543-548.

Tanabe, T., Takeshima, H., Mikami, A. , Flockerzi, V., Takahashi, H., Kangawa, K., Kojima, M., Matsuo, H., Hirose, T. and Numa, s. (1987) Primary structure of the receptor for calcium channel blockers from skeletal muscle. Nature $328,313-318$. 
Taylor, S.G., Southerton, J.S., Neston, A.H. and Baker, J.R.J. (1988) Endothellum-dependent effects of acetylcholine in $x$ at aorta: a comparison with sodium nitropruselde and cromakalim. Br. J. Pharmaco.?. 94, 853-863.

Topouzis, S., Pelton, T.J. and Miller, R.C. (1989) contractile of fecta of endothelin and $\left(\mathrm{Ala}^{3}{ }^{11}\right)$ endothel in in rat isolated aorta. Br. J. Pharmacol. 96, 101P.

Trahey, M. and MeCormick, K. (1987) A cytoplasmic protein st imulates norma 1 N-ras p21 GTPase, but does not affect oncogenic mutants. Science 238, 542-545.

Triggle, D.J. (1980) Desengitization. Trends in Pharmacol. Sci. 1, 395-399.

Triggle, D.J. (1984) Cellular calcium metabolima activation and antagoniam. J. Asthma $21,375-385$.

Tsien, R.w., Lipscombe, D., Madison, D.V., Bley, K.R. and Fox, A.P. (1988) Multiple type of neuronal calciun channels and their selective modulation. Trends Neurosci. 11, 431-438.

Uchida, צ., Ninomiya, H., Saotono, M., Nomura, A., Ohtsuka, K., Yanagisawa, M., Goto, K., Naskai, T. and Hasegawa, s. (1988) Endothelin, a novel vasoconstricotr peptide, as a potent bronchoconstrlctor. Eur. $J$. Pharmacol. 154, 227-228.

van Breemen, C., Aaronson, P., Loutzenhiger, R. and Moisheria, K. (1979) Sodiumcalcium interaction in mammalian smooth muscle. Pharmacol. Rev. 30, 167208.

Vanhoutte, P.M. (1974) Inhibition by acetylcholine of adrenergic neurotransmisaion in vascular smooth musele. Cire. Res. 34, 317-326.

Vanhoutte, P.M. and Katusic, 2.S. (1988) Endothellum-derived contracting factor: Endothelin and/or superoxide anion? Tronds in Phatmacol. Sci, 9:229-230.

Vanhoutte, P.M., Rlmele, T.J. and Flavahan, N.A. (1985) Lipoxygenase and calcium entry in vascular smooth muscle. J. Cardiovasc. Pharmacol. 7, 547-s52.

Vanhoutte, P.M. Rubanyi, G.M., Miller, V.M. and Houston, D.S. (1986) Modulation of vascular smooth meucle contraction by endothellum. Ann. Rev. Physiol. 48, 307-320.

Vanhoutte, P.M. and Miller, V.M. (1989) $\alpha_{2}$-Adrenoceptors and endothellum-derived relaxing factor. Am. J. Med. 87 (3C), 1S-5s.

Vanhoutte, P.M. (1989) Endothelium and control of vascular function: otate of the art lecture. Hypertension 13, 658-667.

Vanhoutte, P.M., Auch-Schwelk, W., Boulanger, C., Jansgen, P.A., Katusic, z.s., Komori, K., Miller, V.M., Schini, V.B. and Vidal, M. (1989) Doos endothelin-1 mediate endothel $i$ um-dependent contractions during anoxia? $\mathrm{J}$. Cardiovasc. Pharmacol. 13 (Suppl. 5) 124-128. 
Van Renterghem, C., Vigne, P., Barhanin, J., Schmid-Alllana, A., Fzelin, C. and zdunski, $M$. (1989) Holeeular mechanism of endothelin-l action on aortic cells. J. Cardiovasc. Pharnacol. 13 (Suppl. 5), S186-\$187.

von Techarner, V., Prod'hom, B., Baggiolini, M. and Reuter, H. (1986) Ion channels in human neutrophile activated by a $r$ ise in free cytosolie calcium concentration. Nature (Lond.) 324, 369-372.

Wallnöfex, A., Welr, S., Rulegg, U. and Cauvin, C. (1989) The mechanism of action of endothelin-1 as compared with other agonists in vascular smooth muscle. J. Cardiovase, Pharmacol. 13 (Suppl. 5) s23-s33.

Watanabe, H., Mlyazaki, H., Kondoh, M., Masuda, Y., Kimura, S., Yanagisawa, M., Masaki, T. and Murakami, K. (1989) Two distinct types of endothelin receptors are present on chick cardiac membranes. Biochem. Biophys. Res. Commun. 161, 1252-1259.

Webb, D.J. (1991) Endothelln zeceptors cloned, endothelin converting enzyme character $i$ zed and pathophyslologieal roles for endothelin proposed. Trends in Pharamcol. Sci. $12,43-46$.

We1, E.P. and Kontos, H.A. (1990) $\mathrm{H}_{2} \mathrm{O}_{2}$ and endothelium-dependent cerebral arteriolar dilation: Implicatione for the Ldentity of endothelium-derived relaxing factor generated by acetyleholine. Hypertengion 16, 162-169.

Weiger, E., Wollberg, z., Kochva, B. and Lee, S.Y. (1984) Cardlotoxic effects of the venom of the burrowing asp, Atractaspis engaddensis (Atractaspididae, Ophidia). Toxicon 22, 767-774.

Wllenan, T., Harding, C., Stahl, P. (1985) Receptor mediated endocytosis. Blochem. J. 232, 1-14.

Wollberg, z., Shabo-shina, R., Intrator, N., Bdolah, A., Kochva, E., Shavit,G., oron, Y., Vinde, B.A. and Gitters, S. (1988) : novel cardiotoxic polypeptide from the venom of Atractaspis engaddensib (Burrowing asp): Cardiac effects in mice and isolated rat and human heart preparations. Toxicon 26, 525-534.

Yanagloawg, M., Inoue, A., Ishikawa, T., Kasuya, Y., Kimura, S., Kumagaye, S., Nakajlma, K., Watanabe, T.X., Sakakibara, S., Goto, K. and Masaki, T. (1988b) Primary structure, synthesis and biological activity of rat endothelin and endothelfum-derived vasoconstrictor peptide. Proc. Natl. Acad. SCI. U.S.A. 85, 6964-6967.

Yanaglsawa, M., Kurihara, H., Kimura, S., Tombe, Y., Kobayashi, M., Mitsui, Y., Yazak, X., Goto, K. and MasakL, T. (1988a) A novel potent vasoconstrictor peptide produced by vascular ondothellal celld. Nature (Lond.) 332, 411415 .

Yanagisawa, M. and Masaki, T. (1989b) Endothelin, a novel endothelium-derived peptide. Biochem. Pharmacol. 38, 1877-1883. 
Yanagisaws, U. and Masaki, T. (1989a) Molecular biology and blochemistry of the endotheling. Trends in Pharmacol. Sci. 10, 374-378.

Yanagisawa, M., Inoue, A., Takuwa, Y., Mitsui, Y., Kobayashi, M. and Masaki, T, (1989) The human preprcendothelin-1 gene: possible regulation by endothelial phosphoinositide turnover signaling. J. Cardiovasc. Pharmacol. 13 (Suppl. 5), s13-s17.

Yoshlzawa, T., Shinmi, O., Giaid, A., Yanagisawa, M., Gibson, s.J., Kimura, s., Uchlyama, Y., Polak, J.M., Masaki, T. and Kanazawa, I. (1990) Endothelin: a novel peptide in the posterior pituitary system. Science $247,462-464$.

Yoshizumi, M., Kuriknra, H., Sugiyama, T., Takaku, F., Yanagisawa, M., Maøaki, T., Yazaki, Y. (1989) Hemodynamlc shear stress stimulates endothelln production by cultured endothelial cells. Biochem. Biophys. Res. Comnun. $161,859-864$.

Zeldel, M.L., Brady, H.R., Kone, B.C., Gullans, S.R. and Brenner, B.M. (1989) Endothelin, a peptide inhibitor of $\mathrm{Na}^{+}-\mathrm{K}^{+}-\mathrm{ATPase}_{\text {in }}$ intact renal tubular cella. Am. J. Physiol. 257, C1101-1107. 


